\title{
مقو لات التحديث المعاصرة في التجربة الإنمائية اليابانية المركبة: الإنجاز والاستمرار والدروس المستفادة إسلامياً
}

*ناصر يوسف

مقدمة:

يعرض هذا البحث أهم مقولات التحديث المعاصرة التي أسهمت بفاعلية في رسم

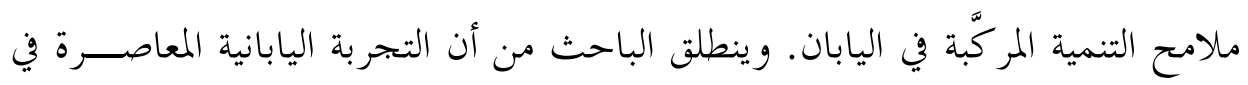

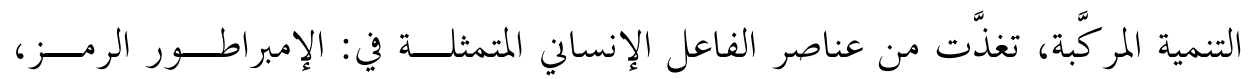

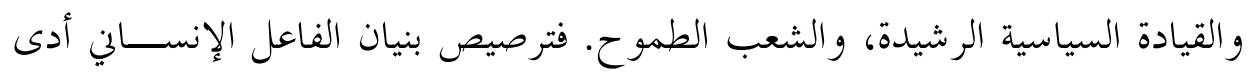

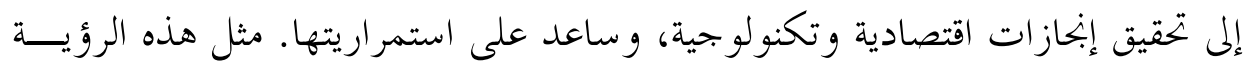
الكلية غير الاختز الية للقضايا الإنمائية هي ما يفترَض من العالم الإسلامي الإفادة منها. و التجربة اليابانية في التنمية المركَّة، ليست أنموذجاً يمكن العثور عليه قابعــاً فــوق

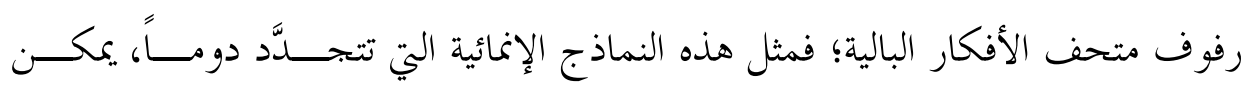

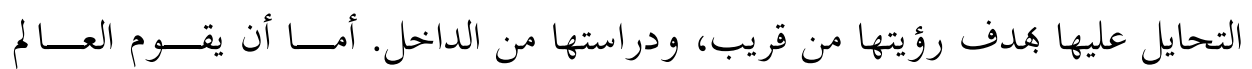

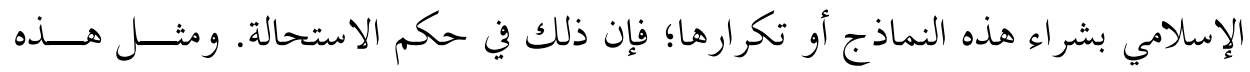

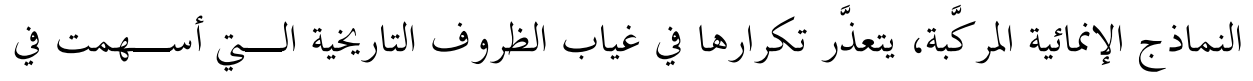
بلورها. إن دراستها من أجل إعادة تطبيقها هو ضرب من العبث التنظيري والمنـــهجي؛ وإنما تدرَس هُدف التساؤل القِلق عن المصير الذي آلت إليه التنمية الاقتصادية في العـــالم

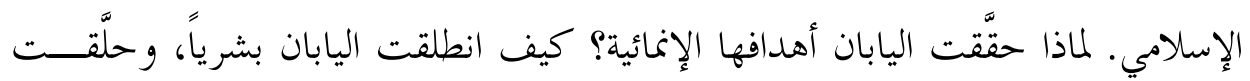

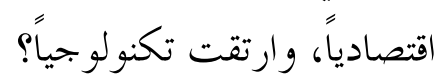




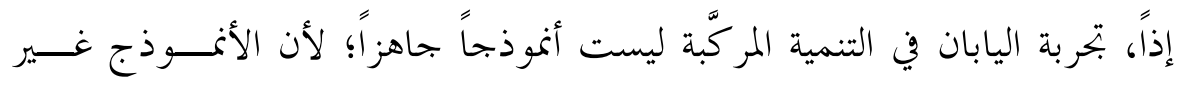

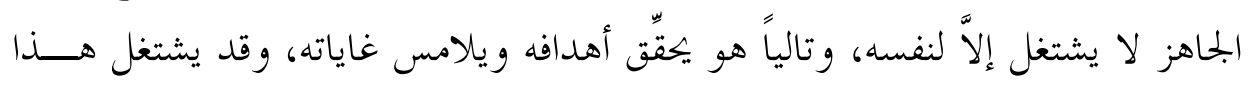

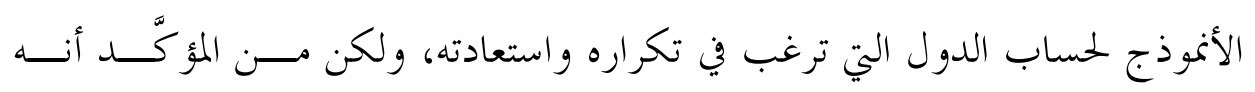

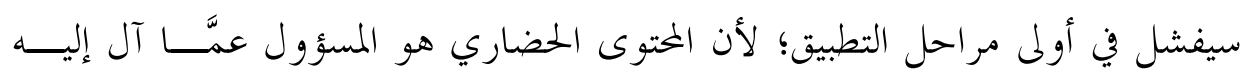

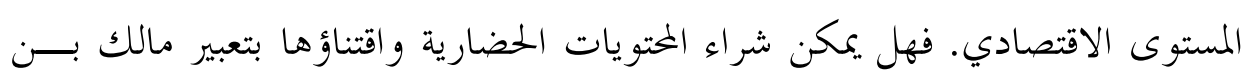

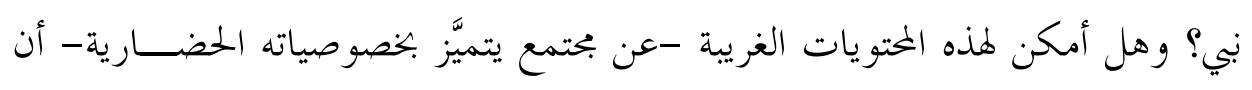
تنجز تنمية؟

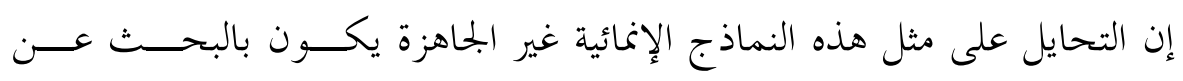

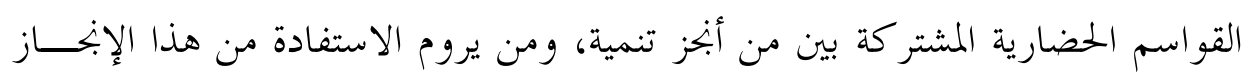

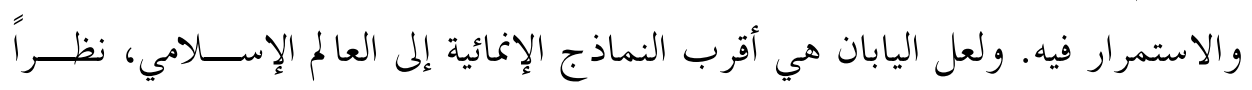

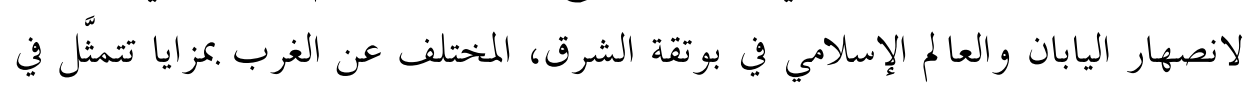

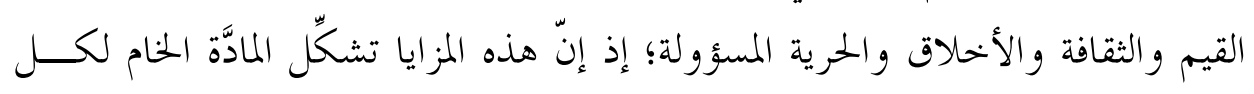

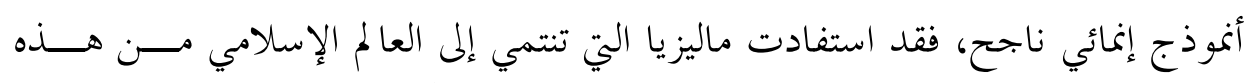

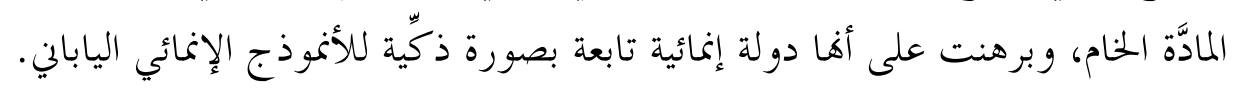

\section{أولاً: من ملامح التجربة اليابانية المعاصرة في التنمية المركَّة}

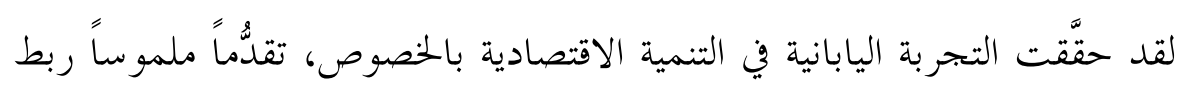

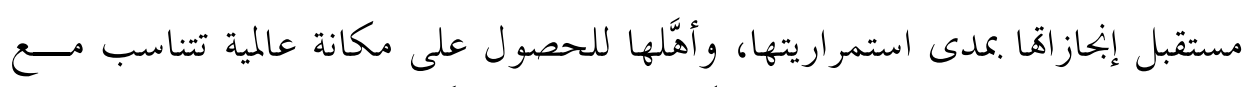

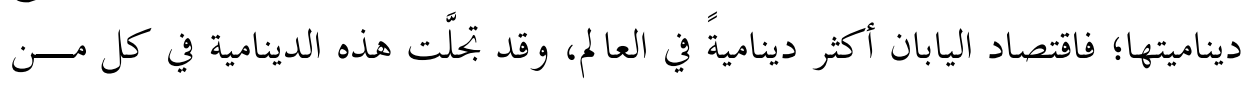

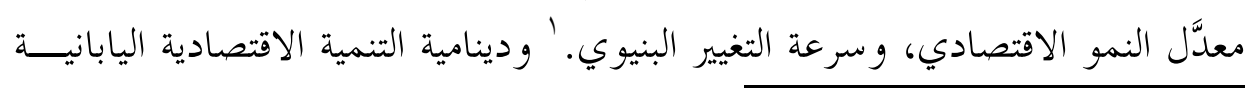

${ }^{1}$ Kohama, Hirohisa. Japan's Development Cooperation and Economic Development in East Asia. In: takatashi Ito and Anee O. Krueger (eds.), Growth Theories in Light of the East Asia Experience, Chicago \& London: the university of Chicago Press, 1995, p216. 
ذات أهمية حاسمة في المنطقة الآسيوية. وقد برزت هذه الدينامية بقوَّة مـــع انطـالِاق

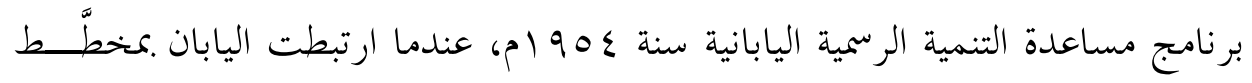

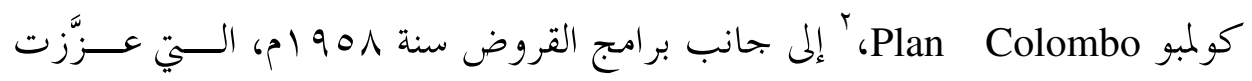

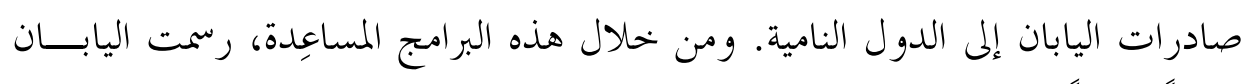

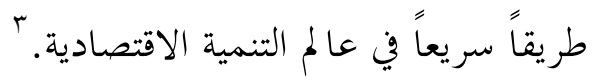

ولقد مرَّت اليابان بمر حلتين حرجتين قبل أن تنجز تنميتها، وهاتان المرحلتان هما:

\section{ا ـ ـقوية الزعة الاقتصادية على الزعة العسكرية:}

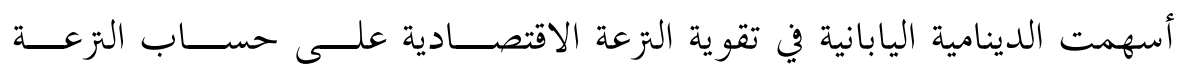

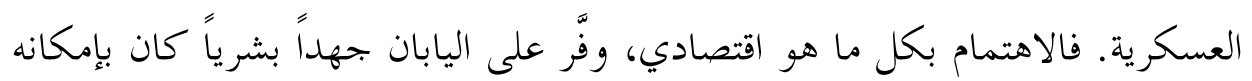

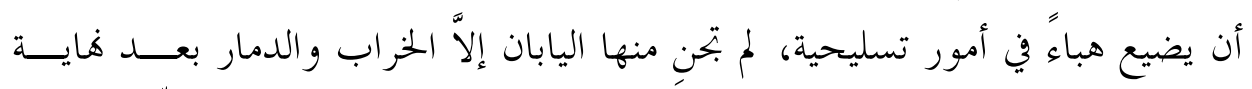

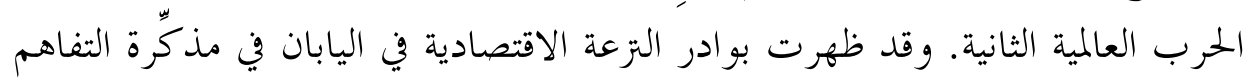

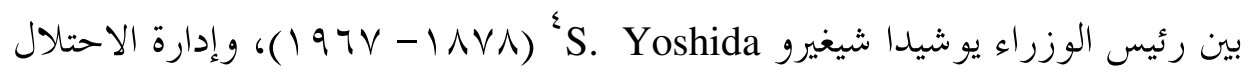

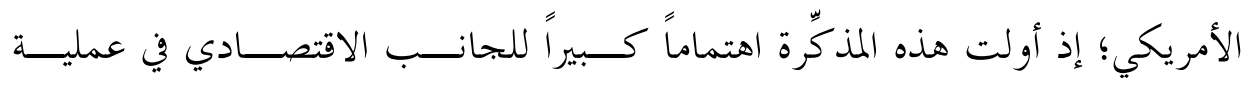

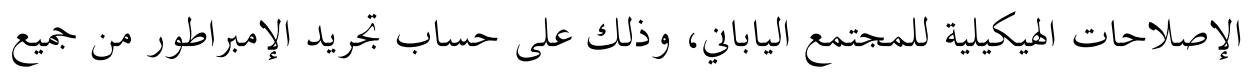

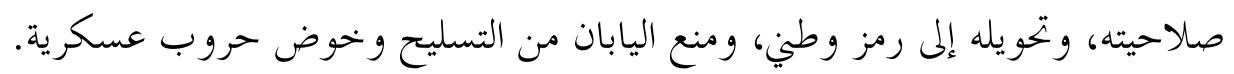

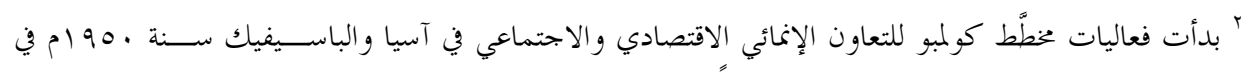

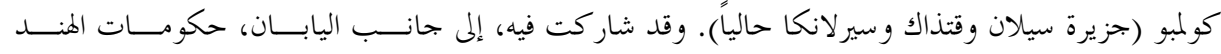

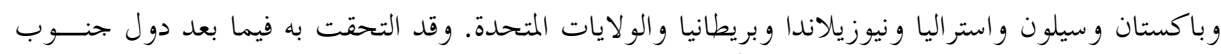

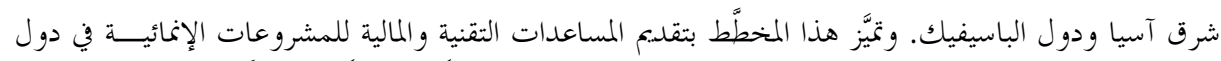

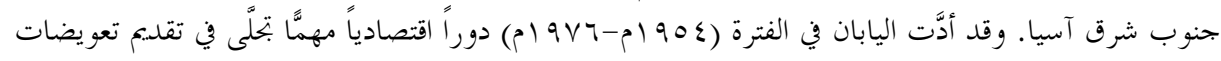

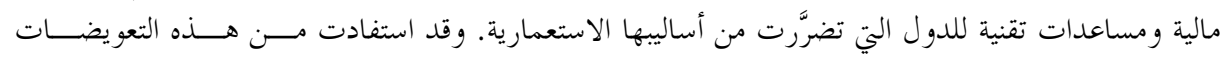

${ }^{3}$ Ibid., p201.

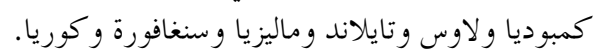

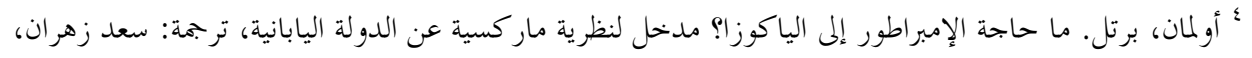

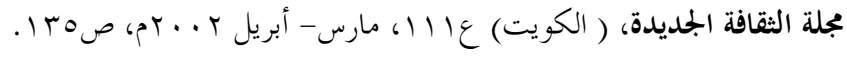


لقد استفاد اليابانيون من الجانب المضيء في فترة إصلاحات (ميجي)، خاصة فيما

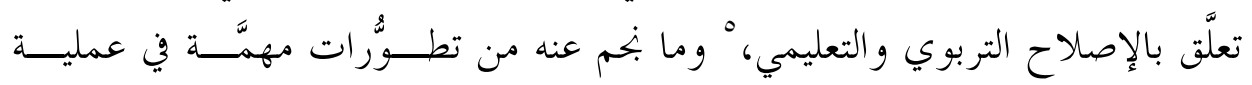

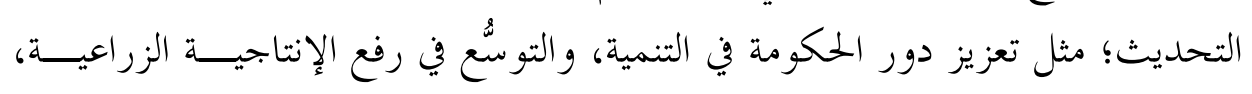

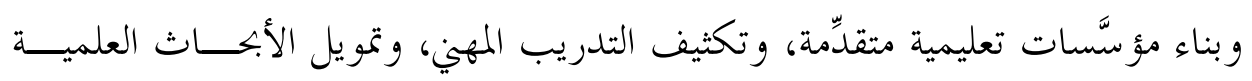

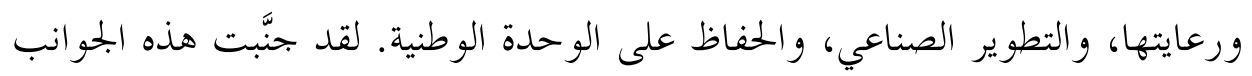

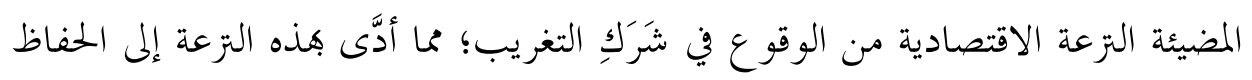

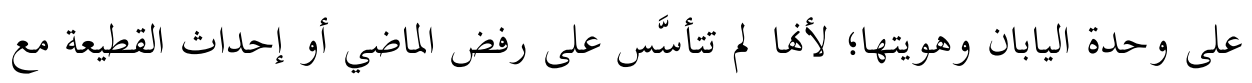

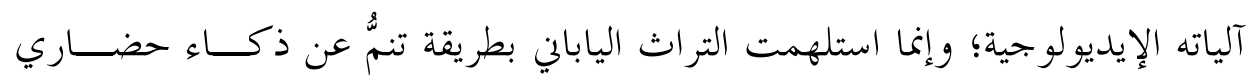

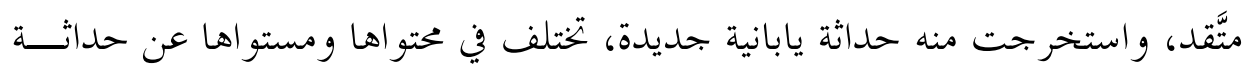
الغرب. وغنيّ عن البيان أن اليابان قد تفوَّقت في إبداع أنموذج إنمائي جديد يتميَّــز بقيـــادة

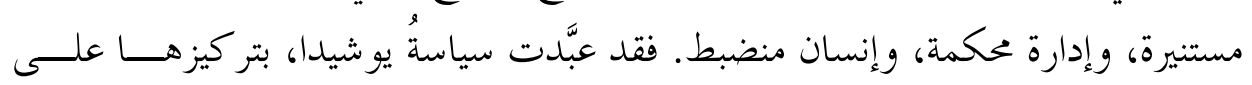
الاقتصاد وترتيب الأمن مع الولايات المتحدة الأمريكية، الطريقَ لأربعة عقود من الرخاء

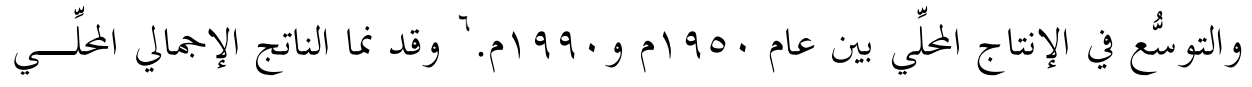

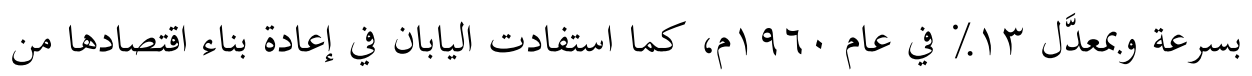

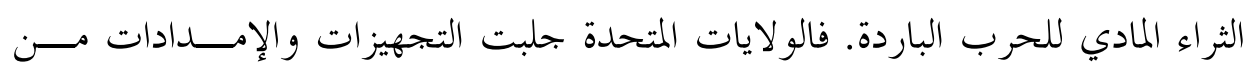

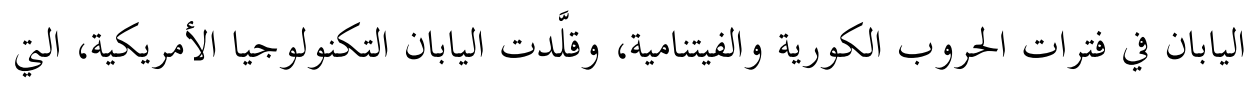

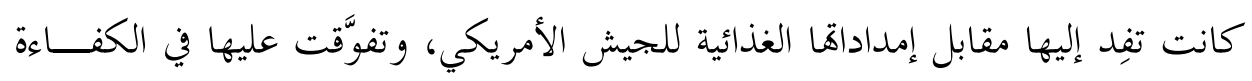

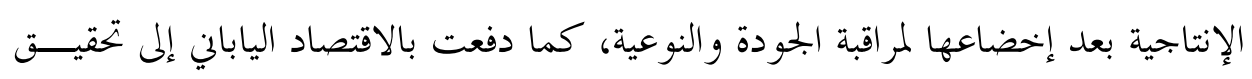

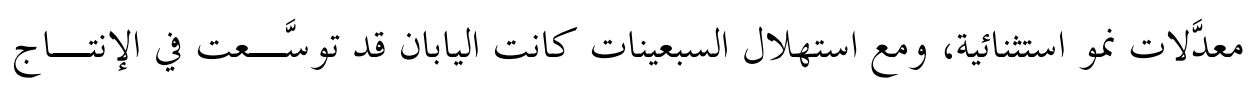
" بوشامب، إدوارد.ر. التربية في اليابان المعاصرة، ترجمة: محمد عبد العليم مرسي، القــاهرة: دار الهدايسـ، طץ،

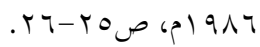

${ }^{6}$ Graham, Eaum. Japan's Sea Lane Security, 1940- 2004: A Matter of Life and Death? London and New York: Routledge, $1^{\text {st }}$ Ed, 2006, p93. 
الصناعي، وتمكنّت من الاحتكاك التجاري مع أوروبا وأمريكا. ل وبعد الطفرة النفطيسـة

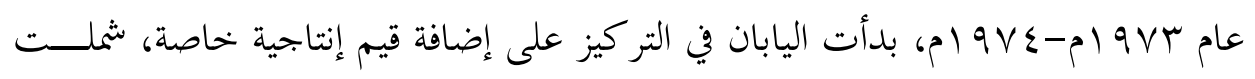

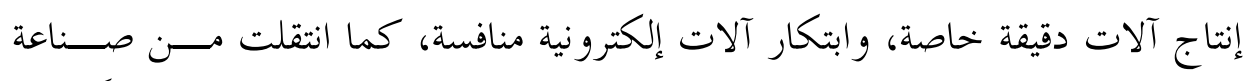

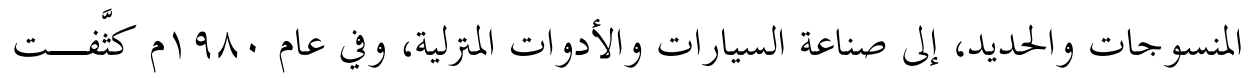

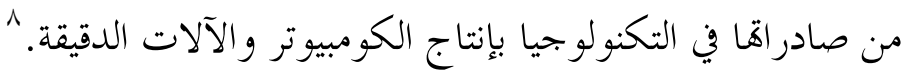

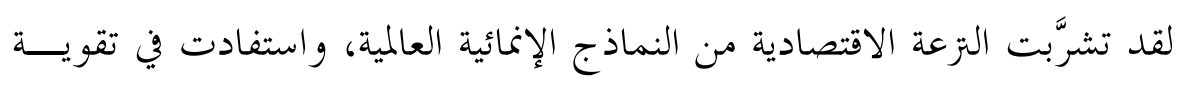

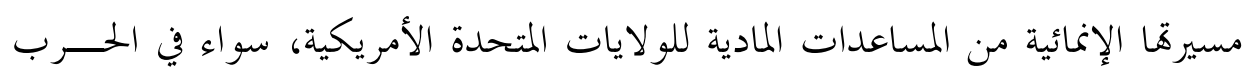

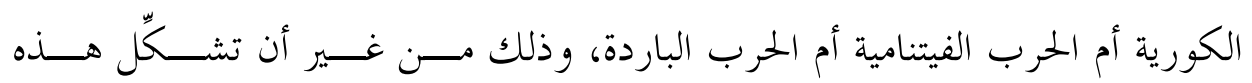

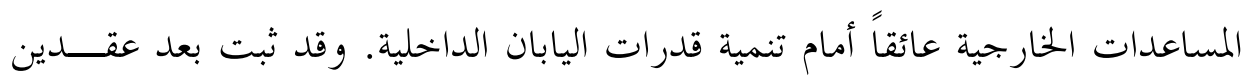

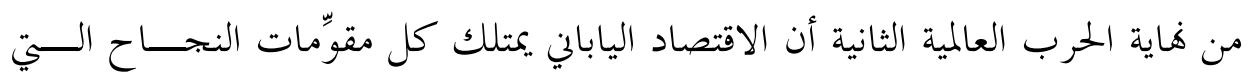

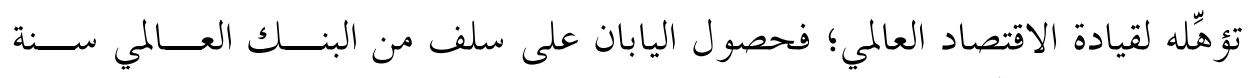

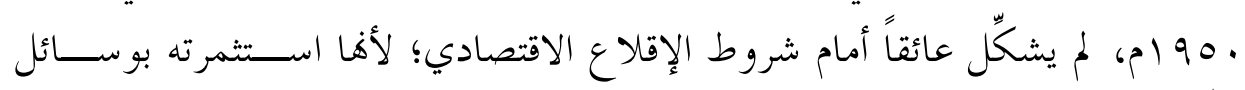
ذكيّة جاءت لصالح البنية التحتية والصناعة الأساسية.

\section{Y ا ت تقوية التزعة الإنسانية على التزعة الاقتصادية:}

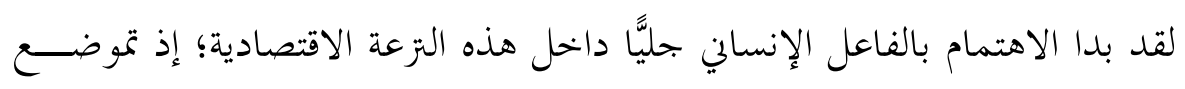

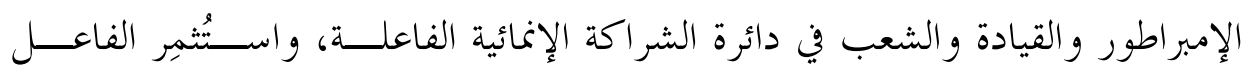

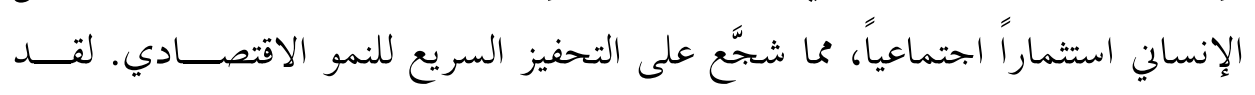

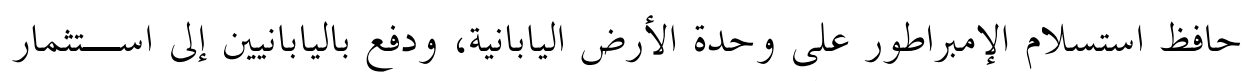

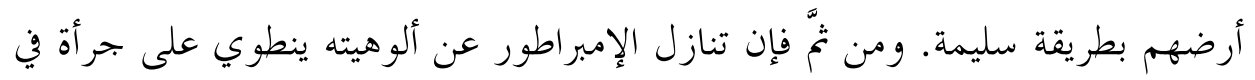

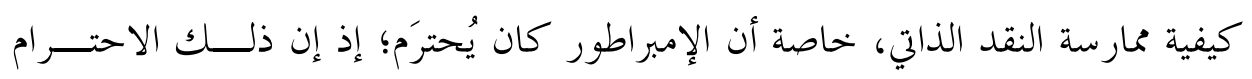

7 Cheok, Cheong Kee and Kah, Wong Choong. Asia Resurgent: Transformation Growth and Integration, Kuala Lumpur: University of Malaya Press, 1st Ed. 2006, pp279-280.

8 Ibid., p292. 
يشكِّل بحسيداً للقيم المطلقة التي يؤمن هما اليابانيون، فمنذ الأيام القديمة لمؤسَّة جيمو Jimmu Foundation

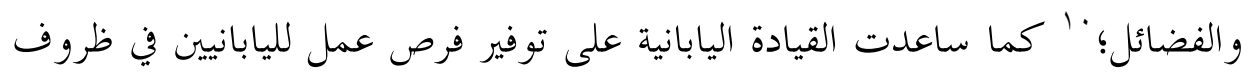
اقتصادية صعبة، وذلك بإعطاء الأولوية للعامل الاقتصادي، وحصر البرنامج الاقتصادي لوكي

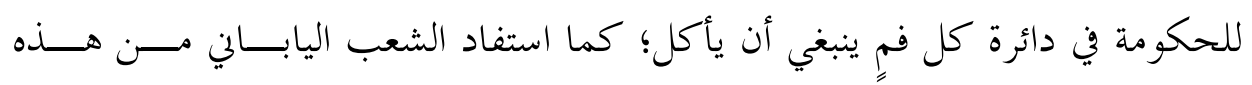

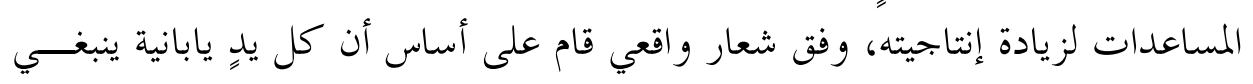

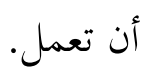
وتمحورت التزعة الاقتصادية حول الفاعل الإنساني، وكسبت شرعيتها الإنمائية من

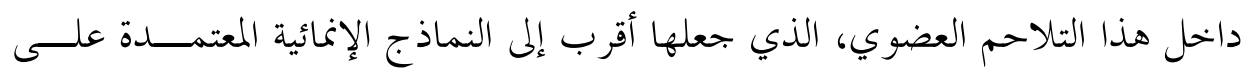
الذات، والملتزمة بروح التعاون و التنافس و الشراكة مع الآخرين. إن ما يميز التنمية اليابانية المعتمدة على الذات، أهذا تنمية مركَّة الأبعاد، وتمتلك القــــدرة

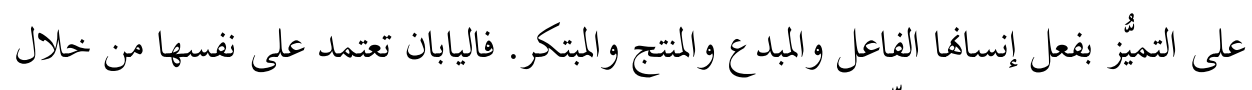

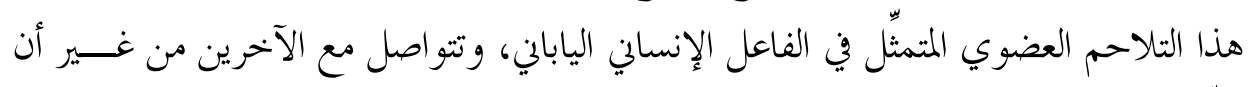

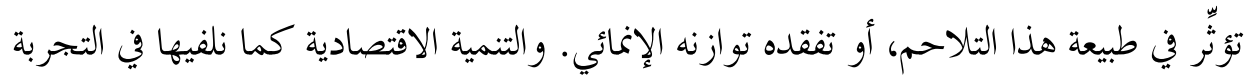

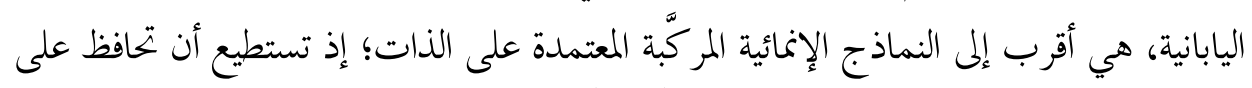

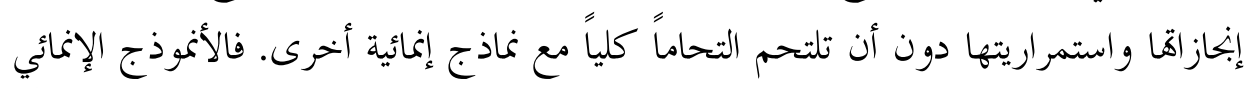

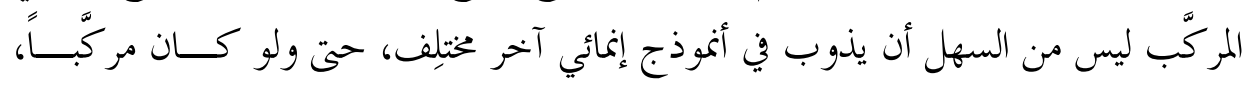
و التنمية المعتمدة على الذات ليس من السهولة، أيضاً، أن تذوب في فئ تنمية أخرى معتمدة على آلى

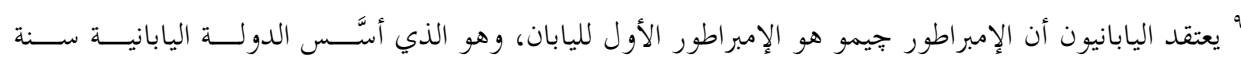

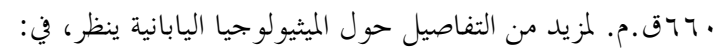

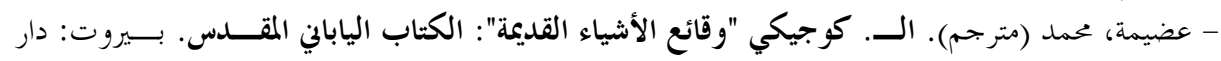

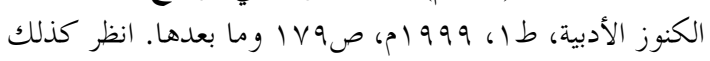

- Andressen, Curtis. A Short History of Japan: From Samurai to Sony, Canberra: Allen \& Unwin, 2002, p27.

${ }^{10}$ Nishikawa, Yukiko. Japan's Changing Role in Humanitarian Crisis, London and New York: Routledge, 1st Ed., 2005, p45. 
الذات؛ فكل" يمثلك خحصوصيته ووحدته وهويته من غير أن يفقد آليات الاتصــال بــالآخر

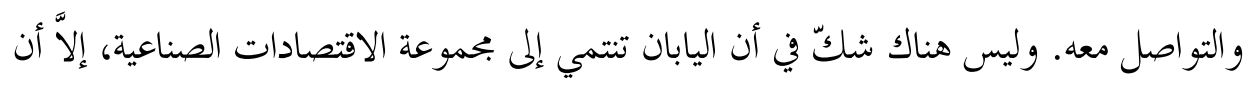

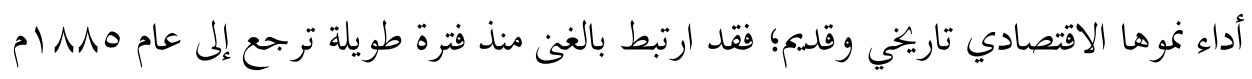

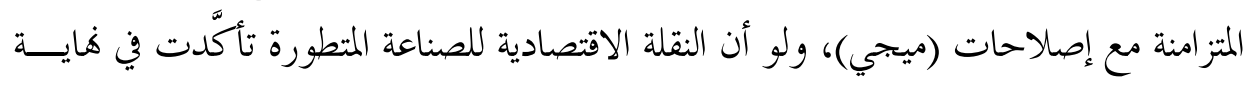

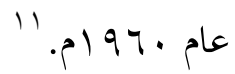

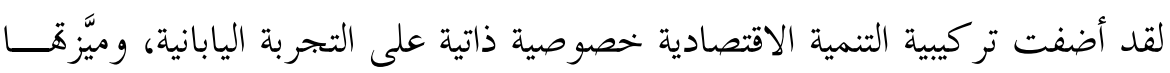

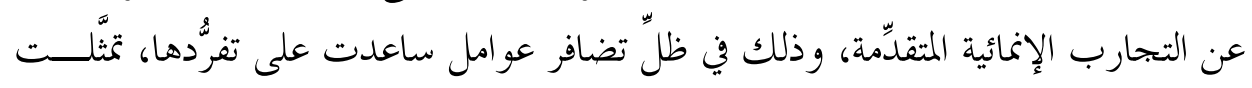

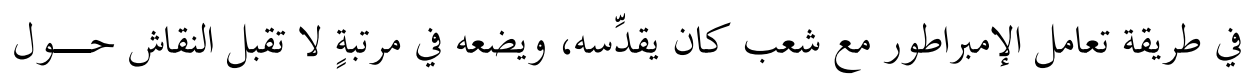

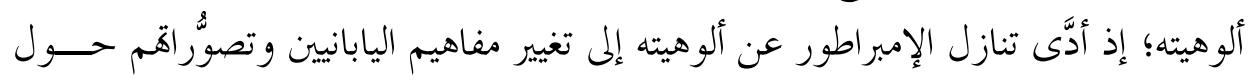

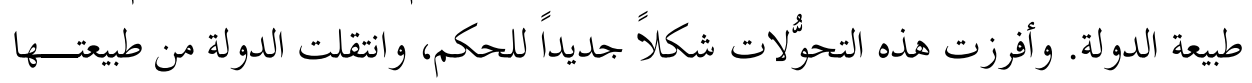

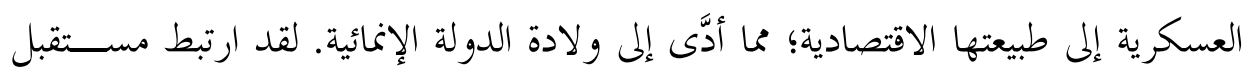

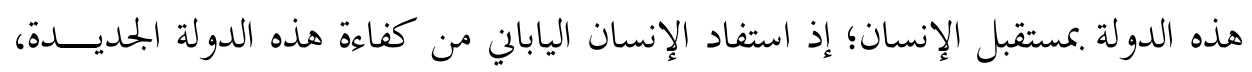

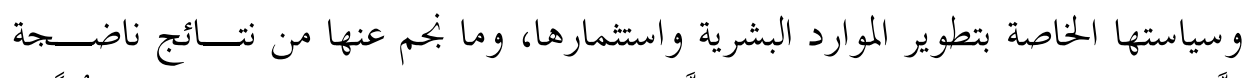

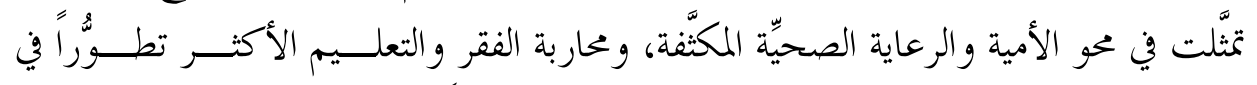

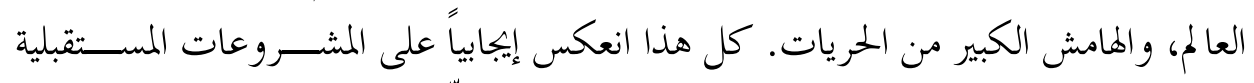

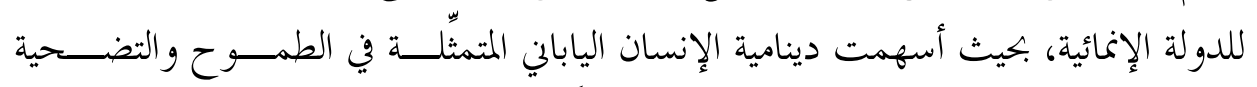

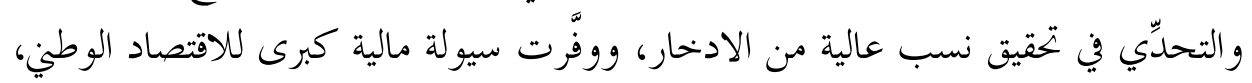

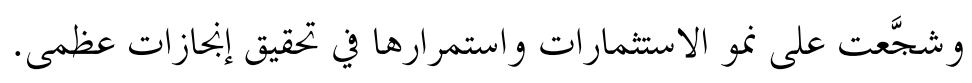

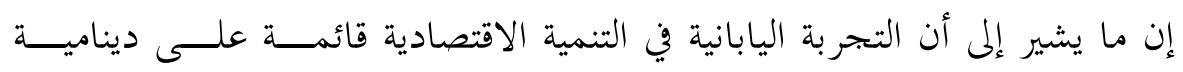

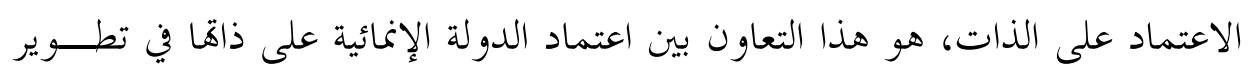

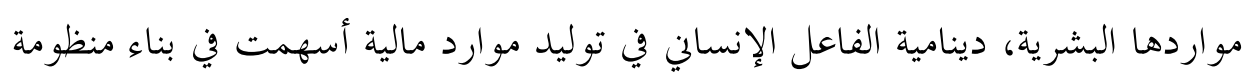
تكنولو جية متميّزة، و كاسحة للأسواق العالمية.

11 Ohkawa, Kazushi. Growth Mechanism of Developing Economies: Investment Productivity and Employment, Tokyo: International Development Center of Japan, 1993, p74. 


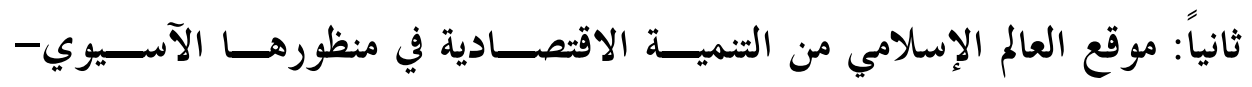
الكونفوشوسي

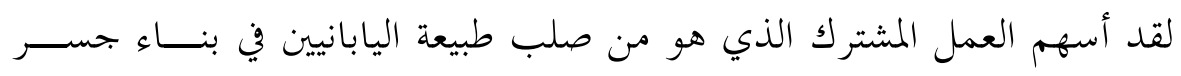

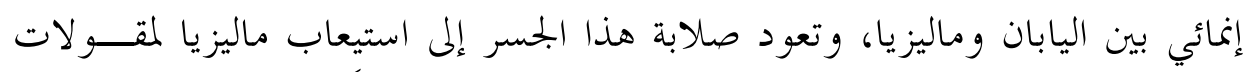

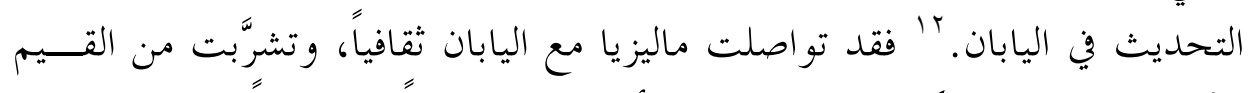

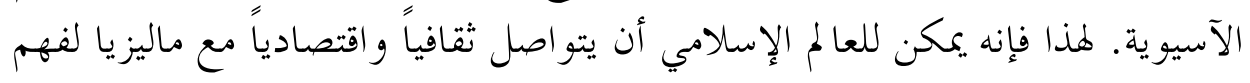

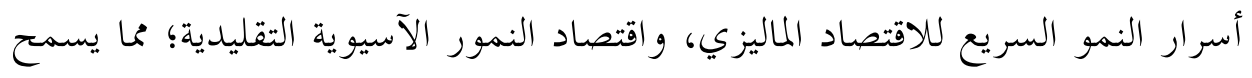

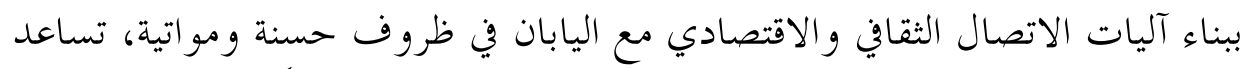

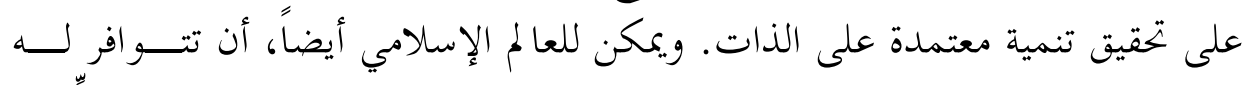

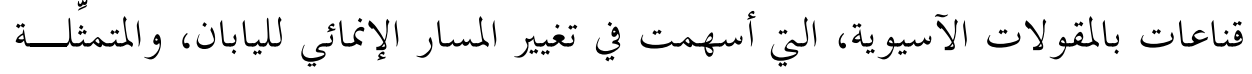

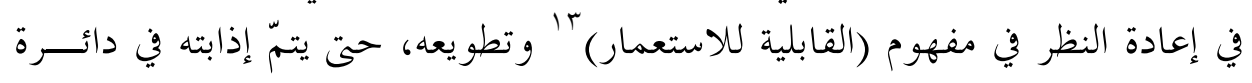

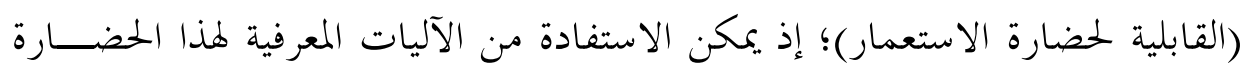

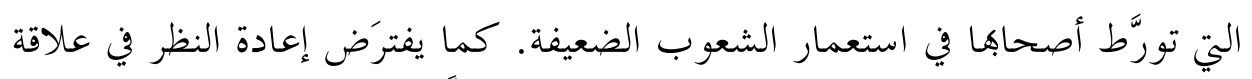

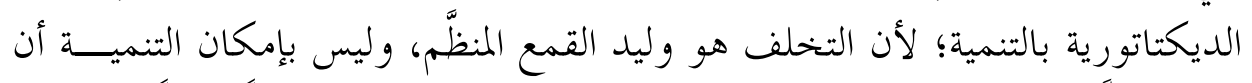

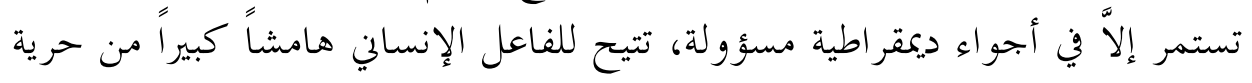

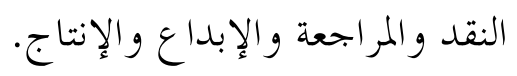

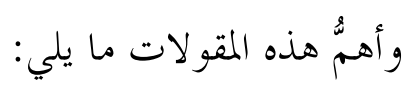

\section{ا ـ الدولة الإنمائية: ثقافة التحرُّر المسؤول}

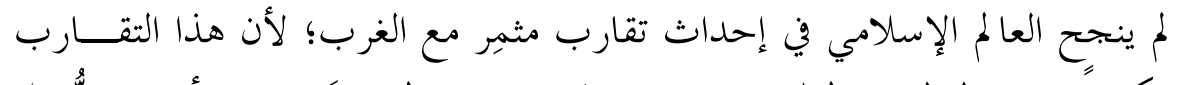

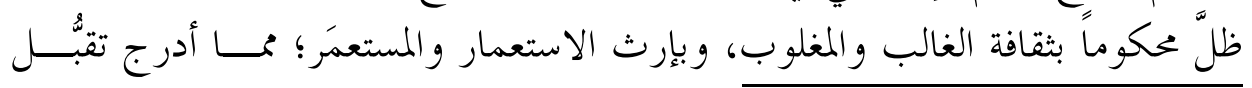

${ }^{12}$ Chong, Terence. Modernization Trends in Southeast Asia, Singapore: Institute of Southeast Asian Studies, 2005, pp7-8.

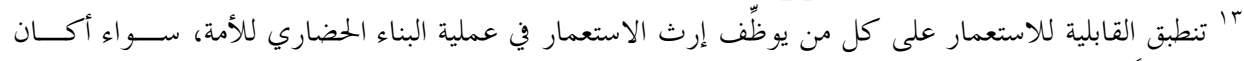

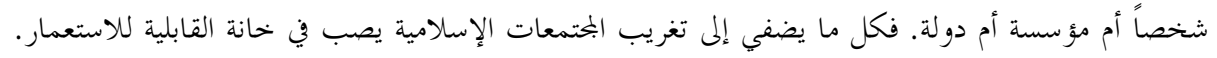




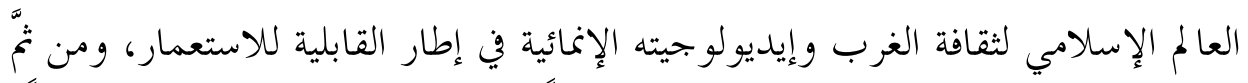
عُدَّت الاستفادة من آليات الغرب المعرفية شكلاً من أشكال القابلية للاستعمار أيضاً.

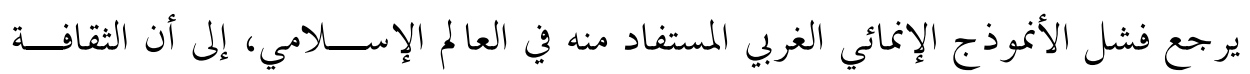

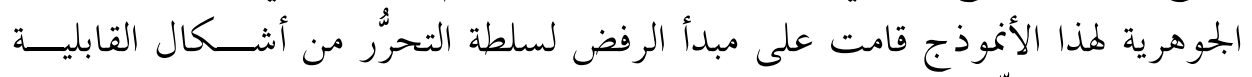
للاستعمار، المتجليّة في تخلف العالم فامت على الإسلامي وتبعيته. مثل هذه الصورة القاتمة تكاد تكون واضحة في الجانب الآخر، فالنمور الآسيوية، كما فيها ماليزيا، أسَّست لثقافة جديدة، هي أقرب إلى ثقافة ما بعد الاستعمار اليابــاني،

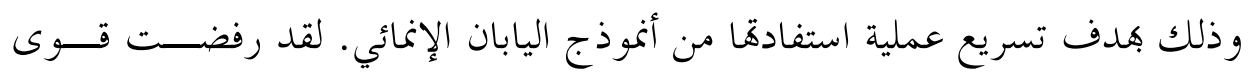

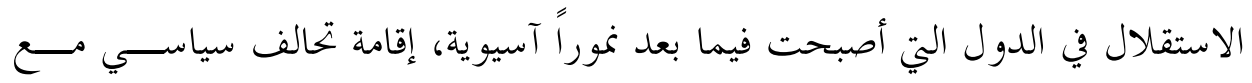
اليابان؛ لأن مثل هذا التحالف، كان سيترجم من قبل بحتمعات هذه الدول إلى القابلية

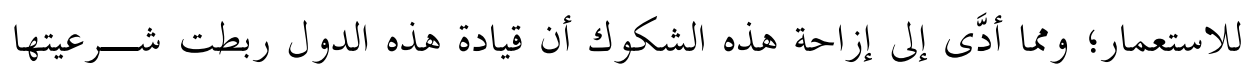

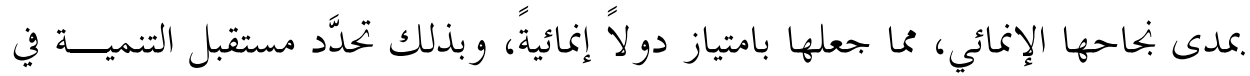

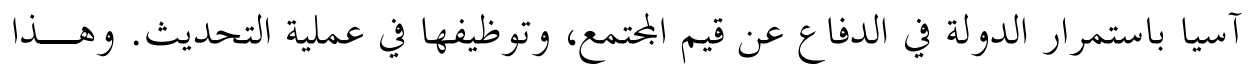
التحالف بين التنمية والدولة حرص على القضاء على أي دعوة للقابلية للاســتعمار، وإلاَّ فإن ذلك كان سيفضي إلى إهدار التنمية وتقويض أساسات البحتمع. مثل هذا الحرص على إبحاح التنمية يعَدُّ التفسير الأول لضعف القابلية للاســتعمار في دول النمور الآسيوية؛ أما التفسير الثاني فيرجع إلى أن اليابان بعد هاية الحرب ألغت

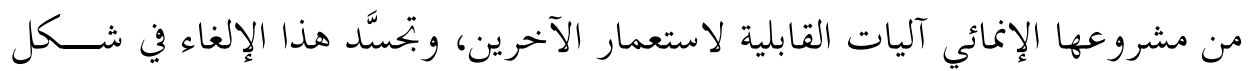
تعاون بخم عنه ولادة نماذج اقتصادية ناجحة في آسيا.

من جهة أخرى، ترجع مشكلة المختمع الدولي إلى غياب الثقة؛ فإرث الاستعمار مـــَّقق

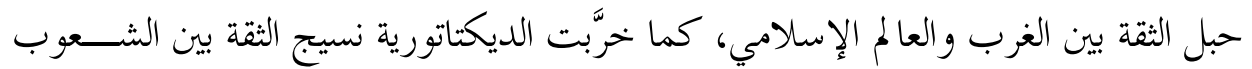

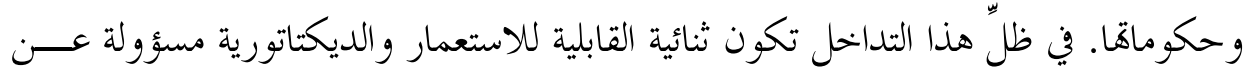
تخلف العالم الإسلامي، وهي نفسها المسؤولة عن تنمية اليابان. إنّ التخلف والتنمية مرتبطان 
مكدى التعامل مع هذه الثنائية، فهناك ثقة متبادلة بين اليابان والنمور الآسيوية صاغتها ثقافـــة

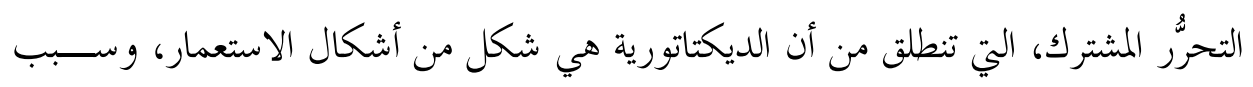

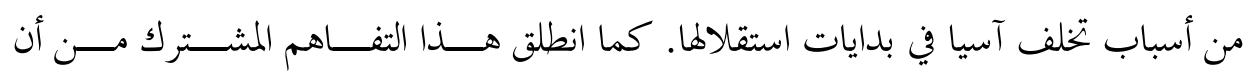

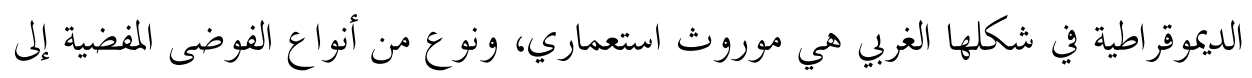

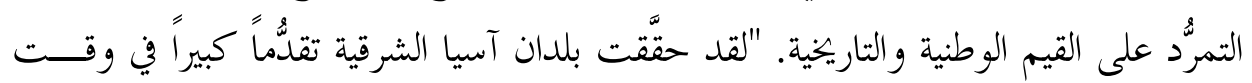

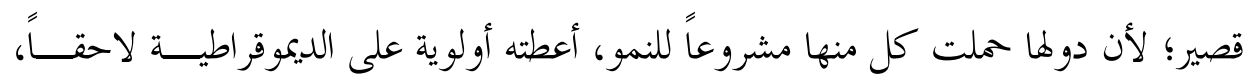

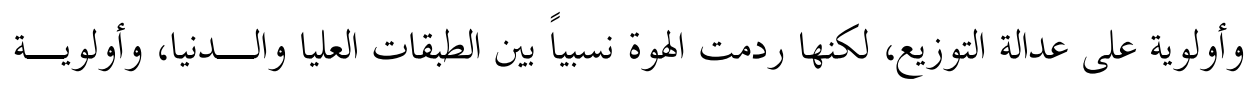

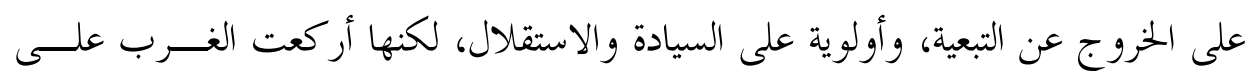

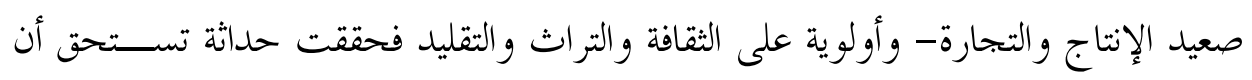

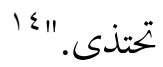

لقد وقفت اليابان والنمور الآسيوية على تحديد فهم مشترك لهذه الثنائية: القابليــة

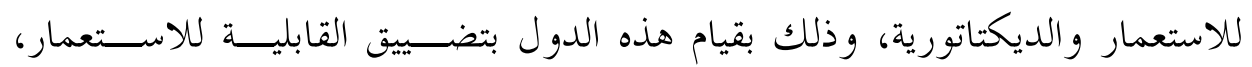

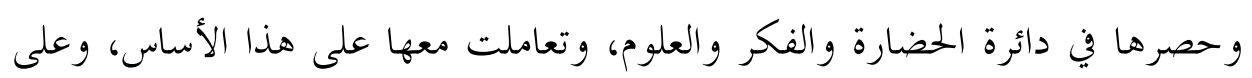

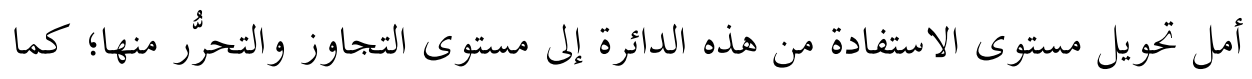

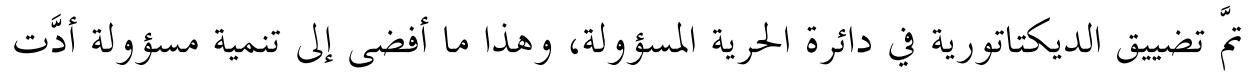
تدريجياً إلى توسيع دائرة الحريات العامة.

لقد أسهم هذا التفاهم الثقافي المشترك بين اليابان والنمور الآسيوية، بما فيها ماليزيسا، في

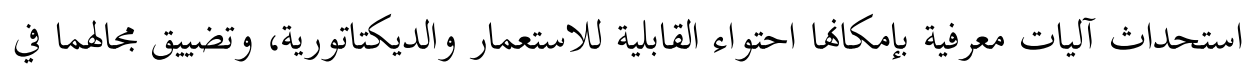

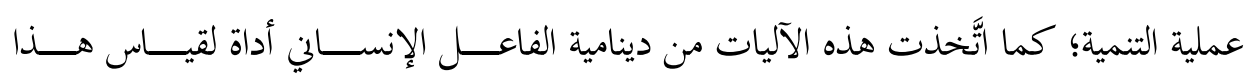

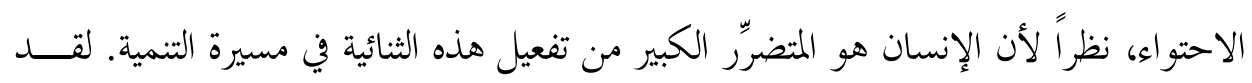

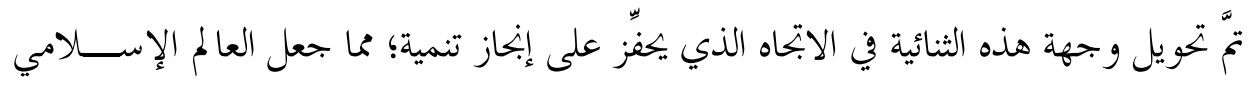
؛ُ شلق، الفضل. الدولة السياسية والدولة الاقتصادية: كيف نستفيد من بتربة دول آسيا الشرقية، مجلة الاجتهاد،

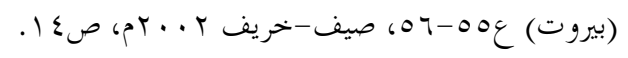


يرى في هذه التنمية الآسيوية مزيجاً من القابلية للاستعمار والديكتاتورية؛ في الوقــت الــــي

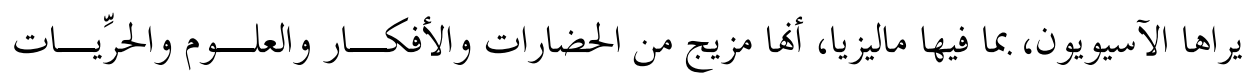

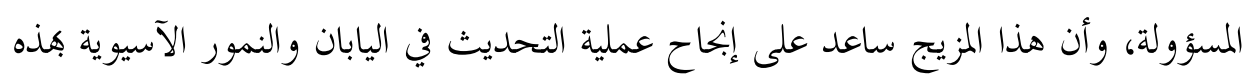
الطريقة السريعة. إن المعالجة الآسيوية لهذه الثنائية وطريقة تعاملها معها، تشكّل جــــوهر الــدروس

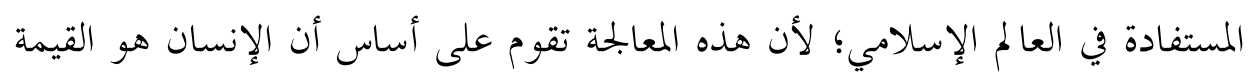

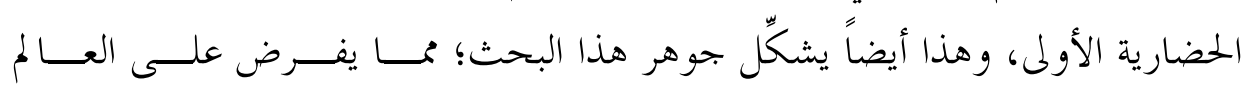

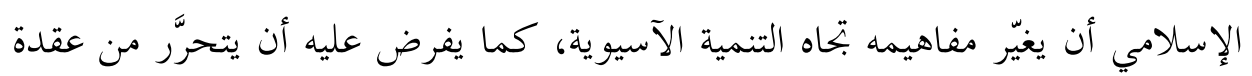

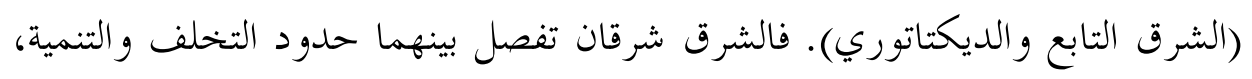
وتميّز بينهما قيمة الإنسان في كل منهما.

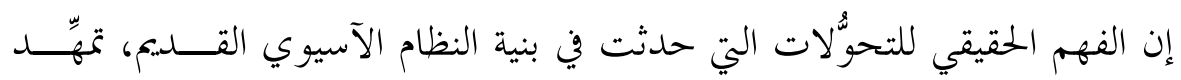

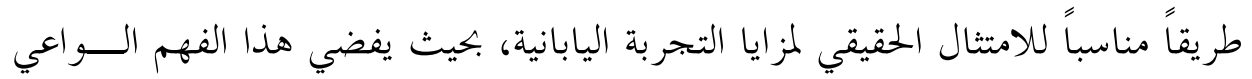

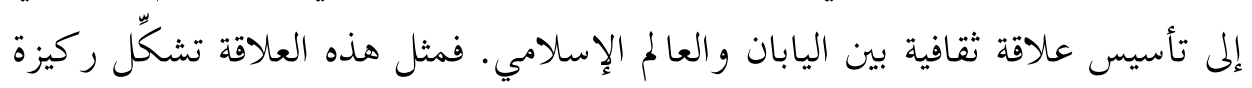

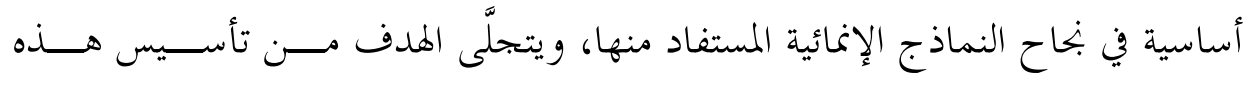
العلاقة في مدى توظيف التقارب بين الثقافتين الآسيوية والإسلامية في مسيرة التنميسـة

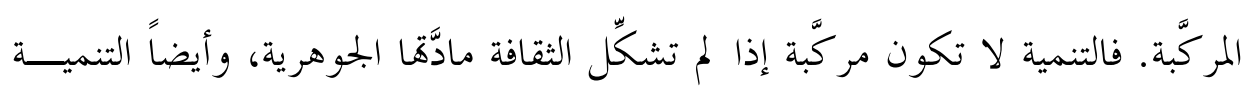

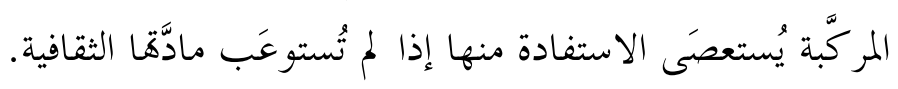

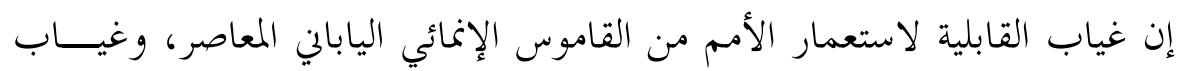

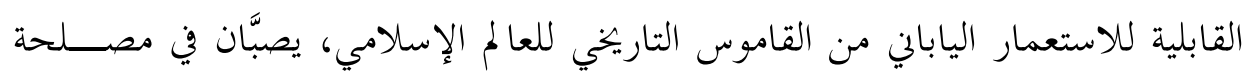

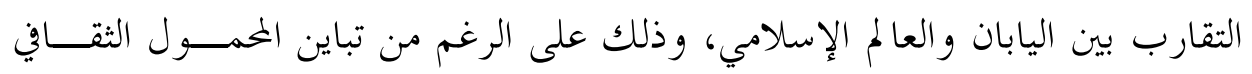

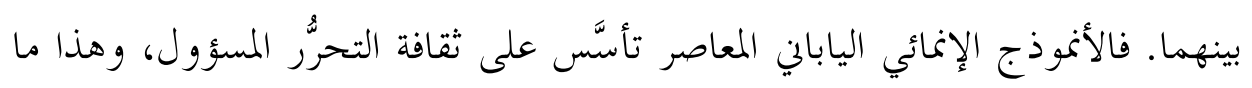

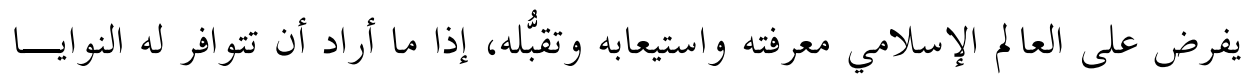

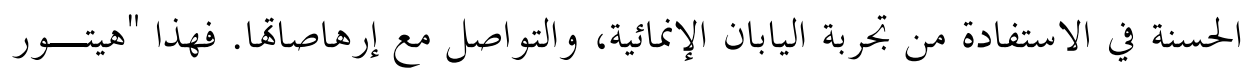




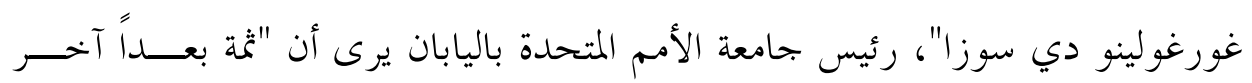

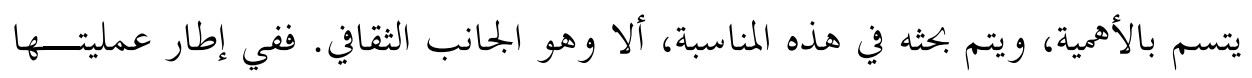

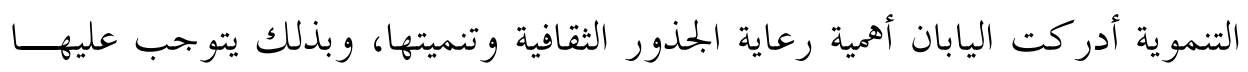

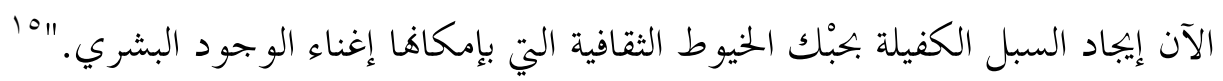

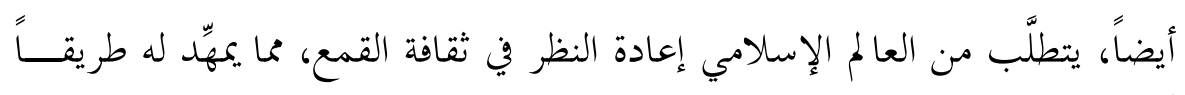

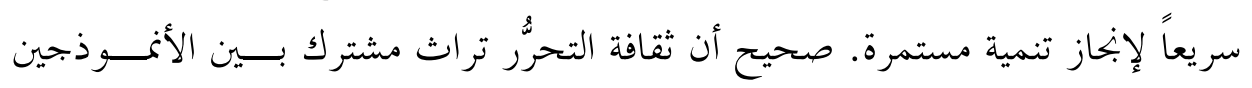

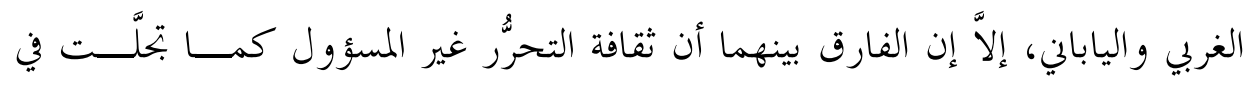

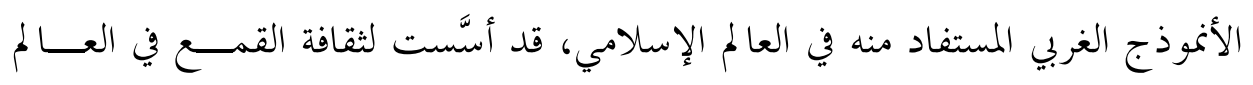

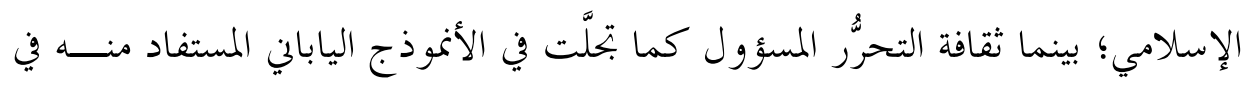

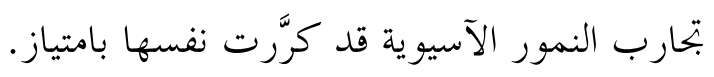

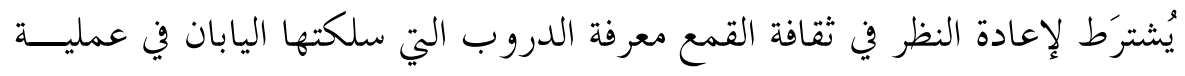

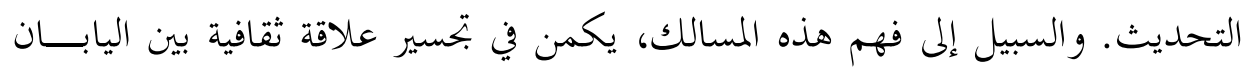

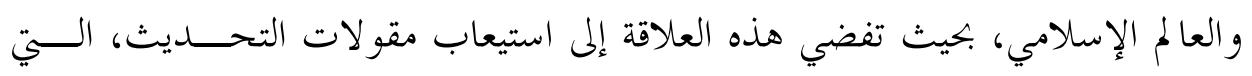

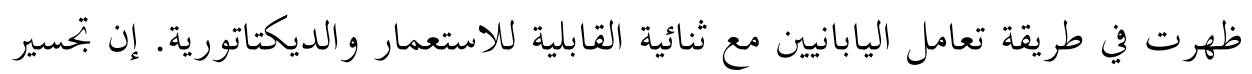

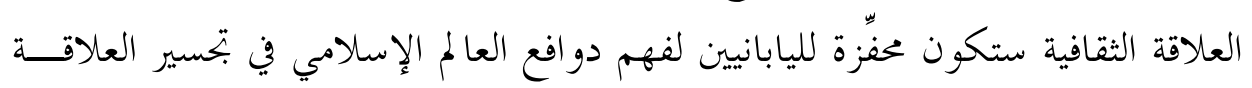

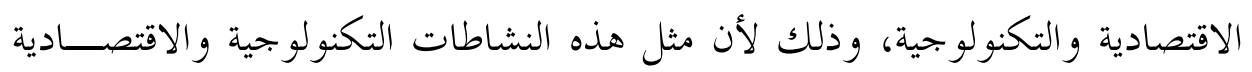

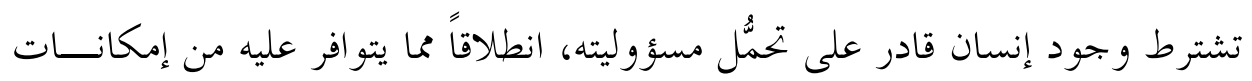

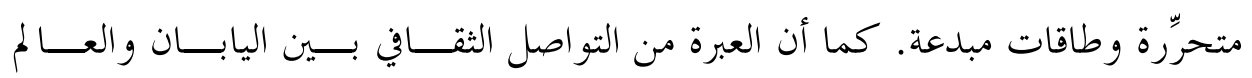

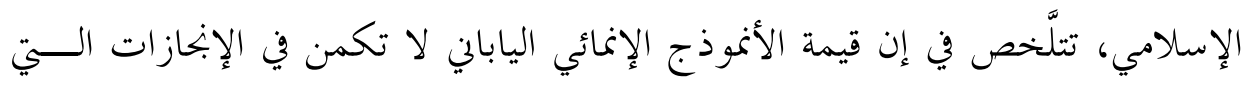

ما انظر الكلمة الترحيبية للسيد هيتور غورغولينو دي سوزا رئيس جامعة الأمم المتحدة باليابان، في:

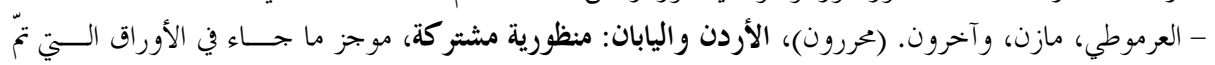

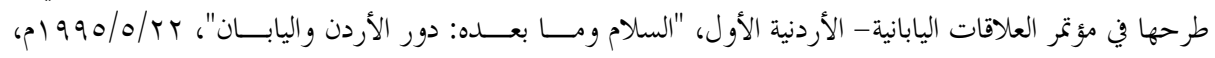

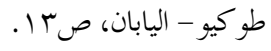


حقَّقها، بقدر ما تكمن في استمرارية هذه الإنحازات داخل شروط إقلاع متجــدِّة،

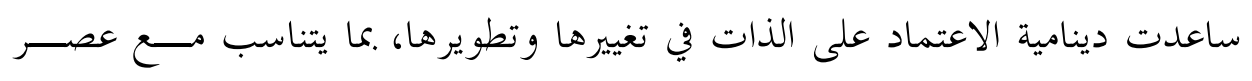
العولمة.

إن غياب ثقافة التحرُّر المسؤول في العالم الإسلامي، بإمكانه أن يعوق الاسـتفادة

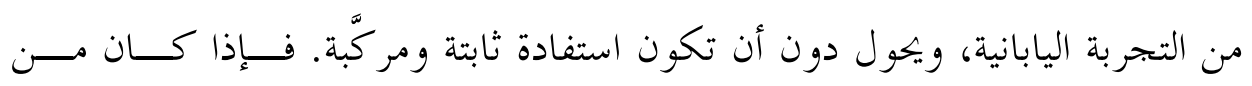

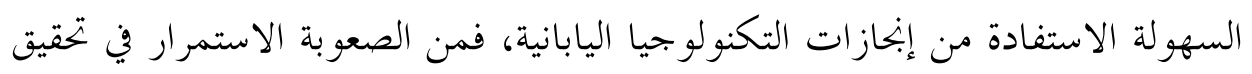

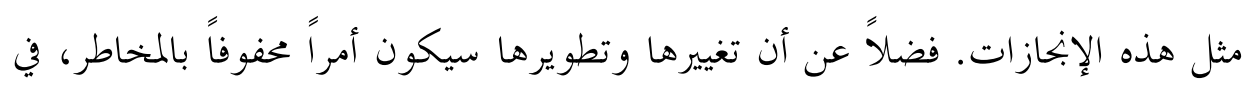

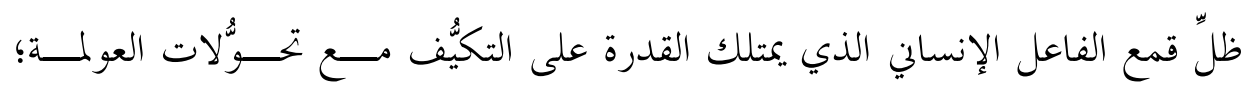

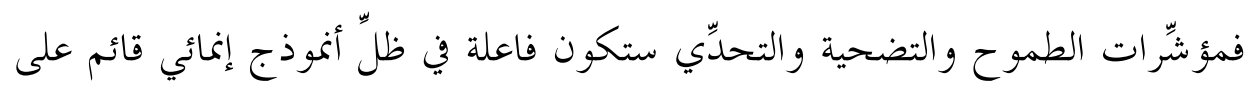

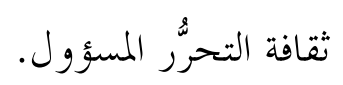

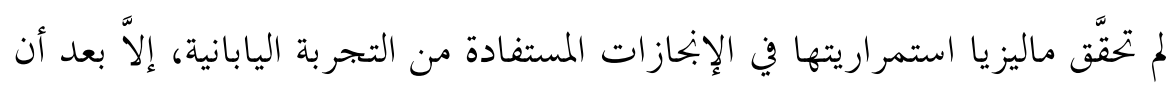

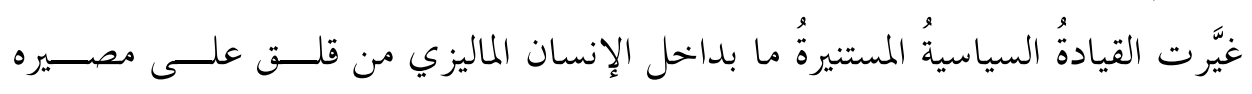

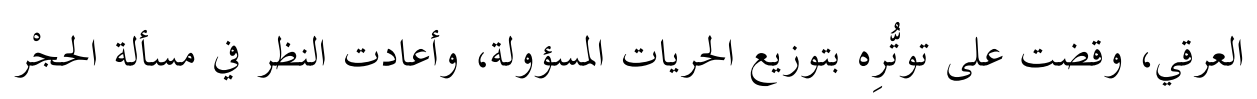

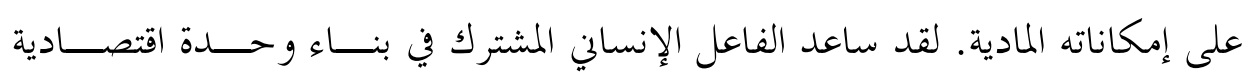

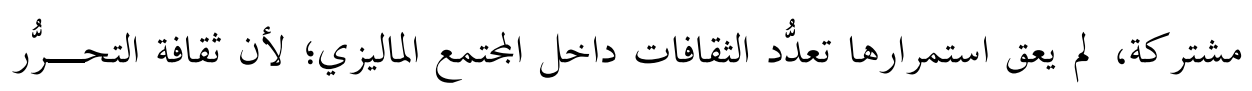

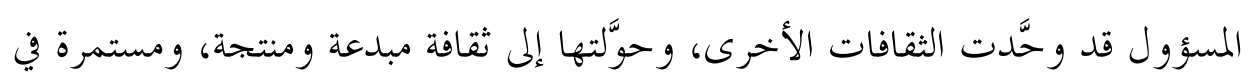
تعزيز دور الإنسان الماليزي في عملية التنمية الاقتصادية.

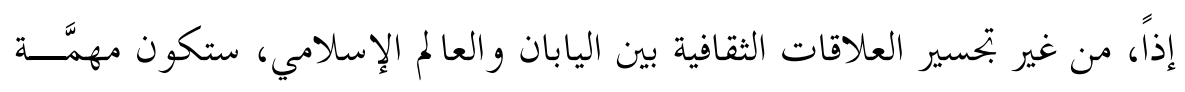

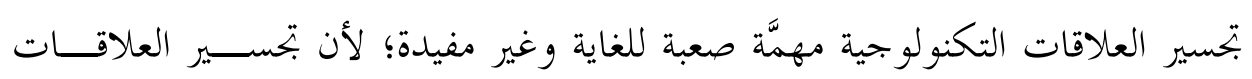

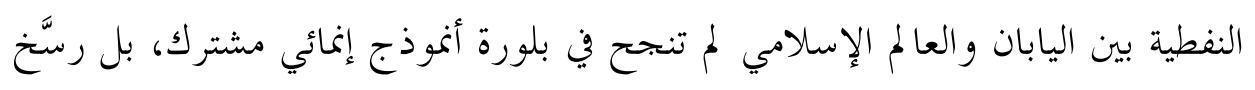

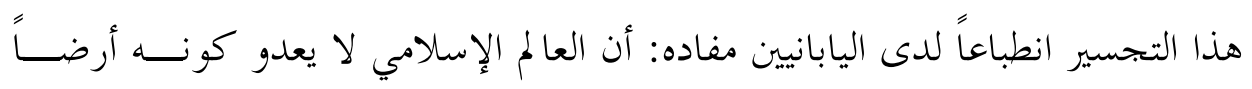




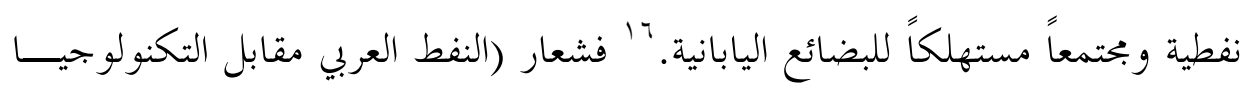

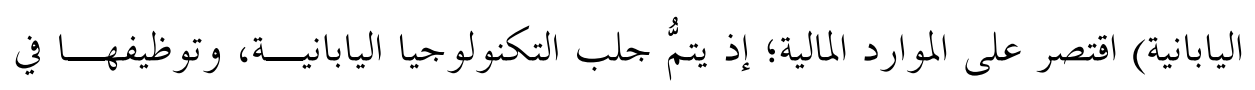

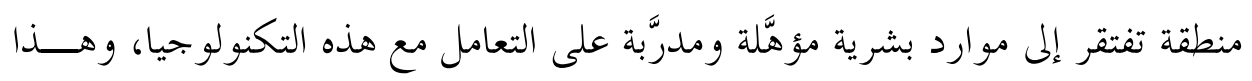

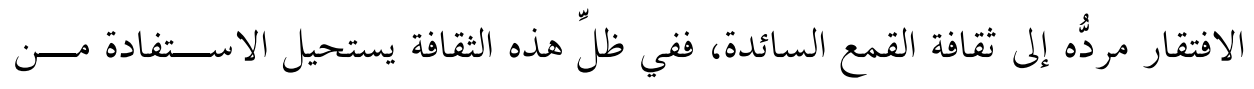

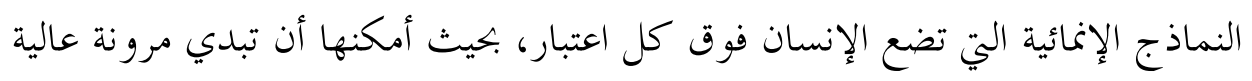

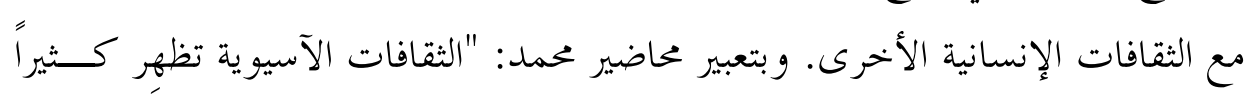

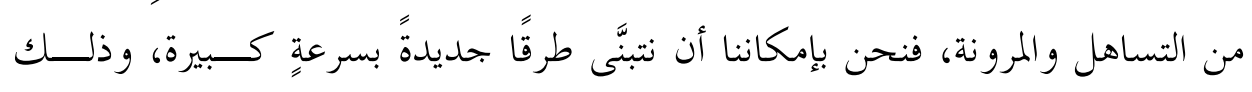

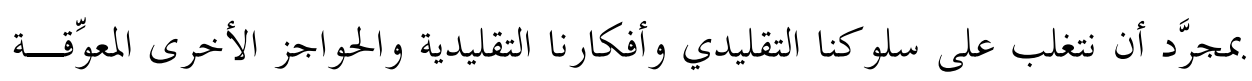

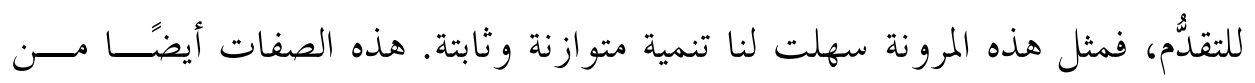

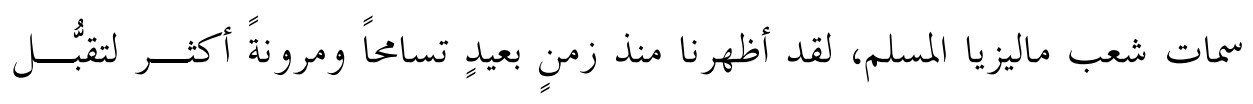
ثقافات مغايرة."

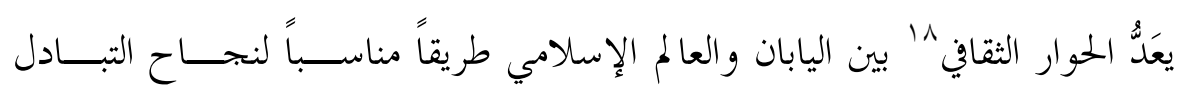

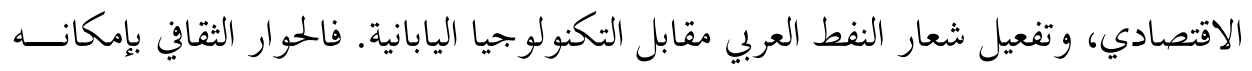

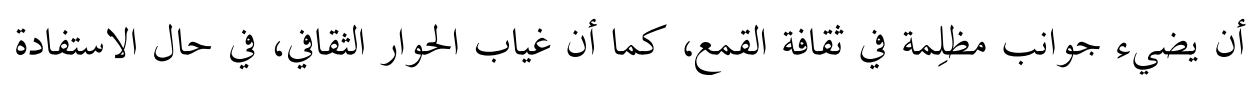

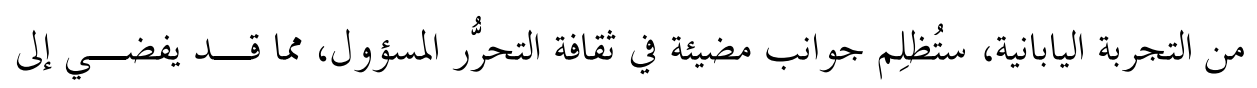
تشويه آليات الاستفادة، وتحويل مسارها في الاتحاه الخطأ.

إن انفتاح أنموذج اليابان الإنمائي على الثقافات والأفكـار و النمــاذج الإنمائيسـة

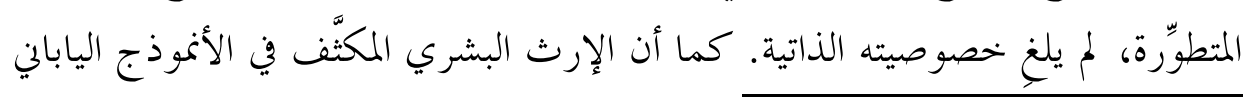

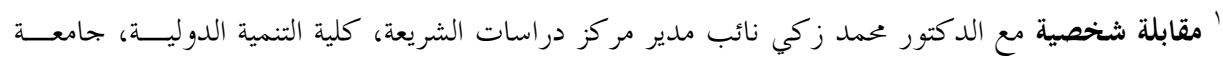

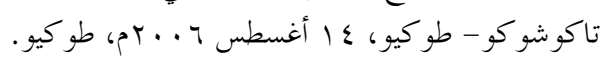

${ }^{17}$ Mohamad, Mahathir and Ishihara, Shintaro. The Voice of Asia, Tokyo: Kadansha International, Ltd, 1995, pp72-73.

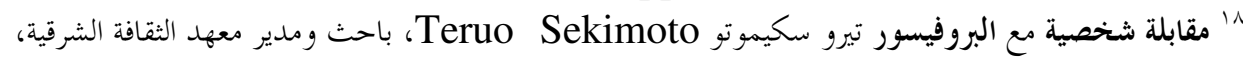

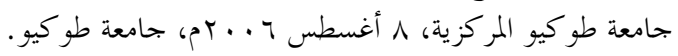




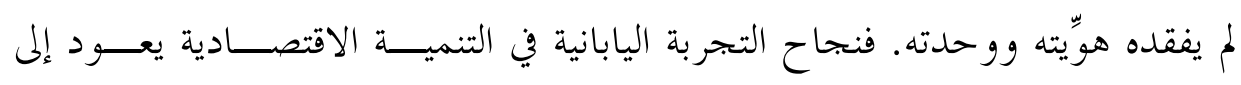

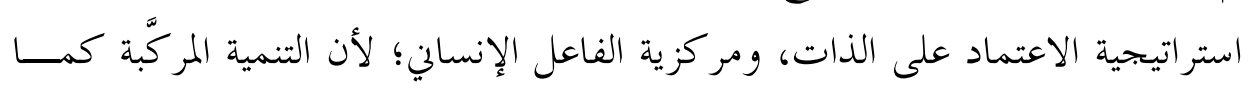

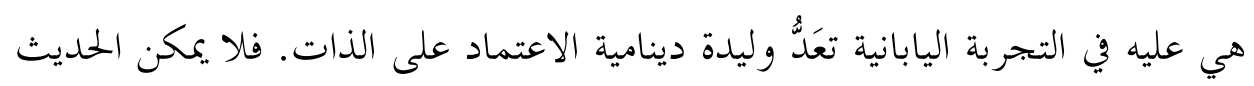

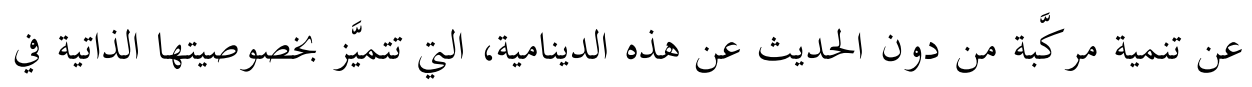
كل تخر بة إنمائية، وإلاًّ ستتعرَّ إلى المساومة على ملى مر كزيتها.

\section{r. ب. مر كزية الفاعل الإنساني: التنمية المركَّة}

تضفي مركزية الفاعل الإنساني في التجربة اليابانية بعداً مركَّاً على التنمية الاقتصـادية

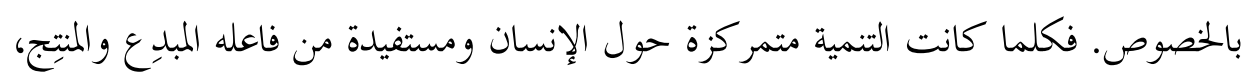

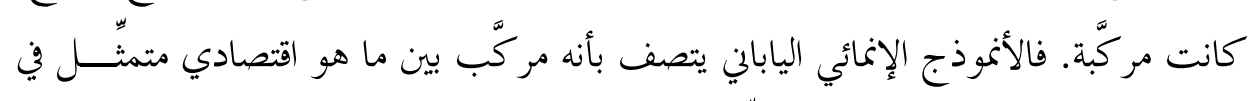

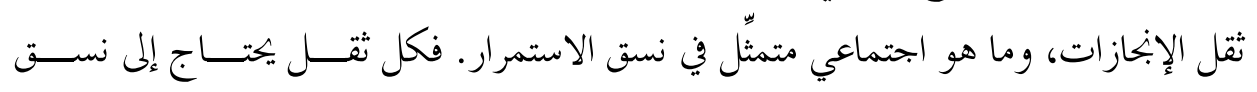

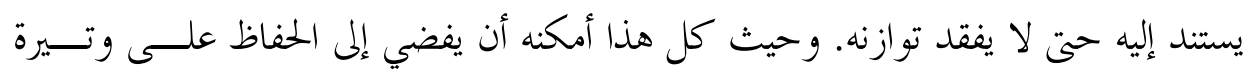

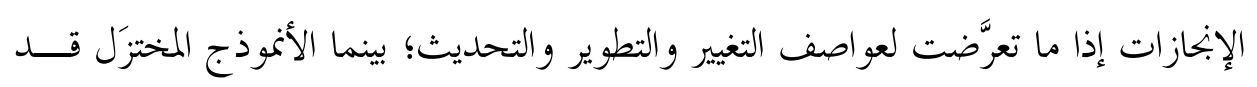

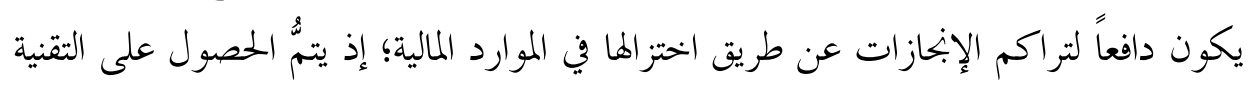

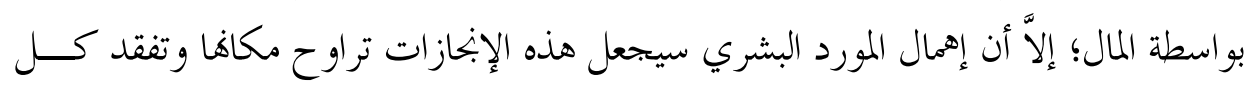

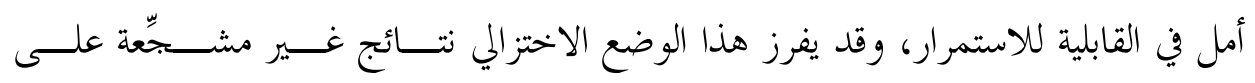

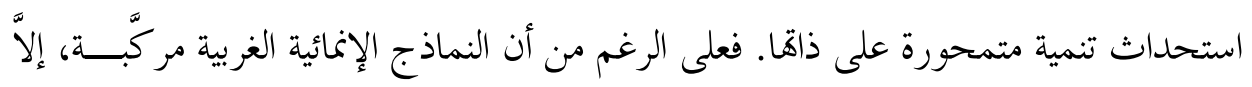

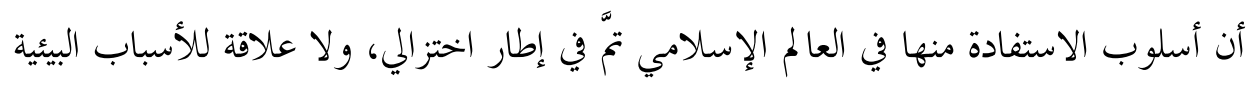

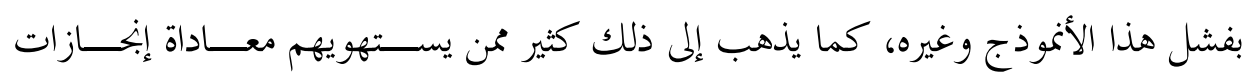
الغرب. فلم يعد عامل البيئة يشكّل عائقاً أمام بناح النماذج الإنمائية المستفاد منها.

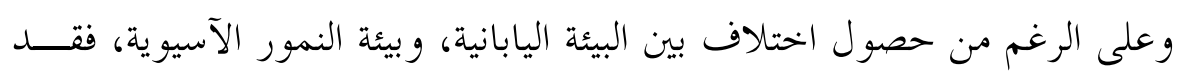

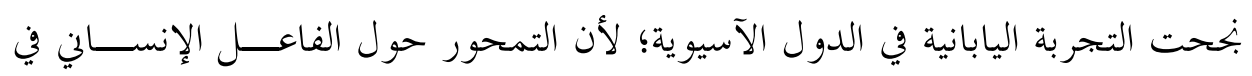

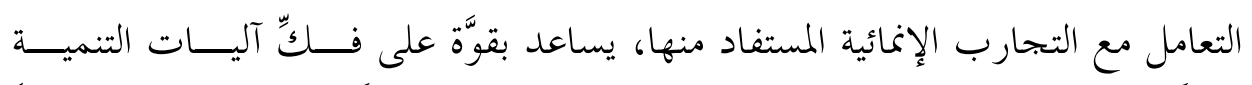

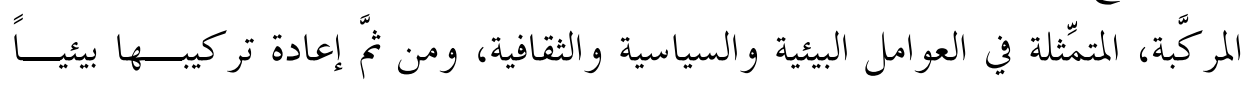


بو ساطة الفاعل الإنساني لا بغيره. إن سبب بناح النمور الآسيوية، بما فيها ماليزيا، التي

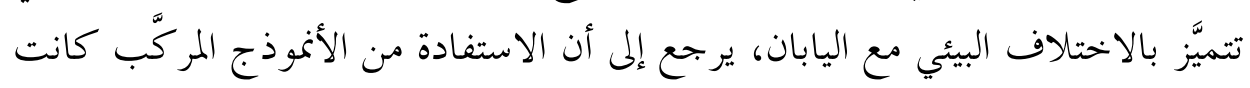

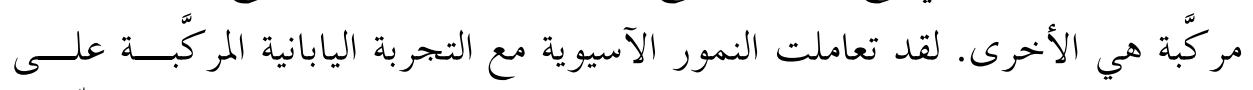

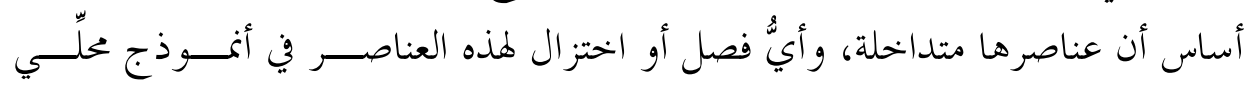
الختزالي سيؤدي إلى الإخفاق في فهم تركيبية التجربة اليابانية.

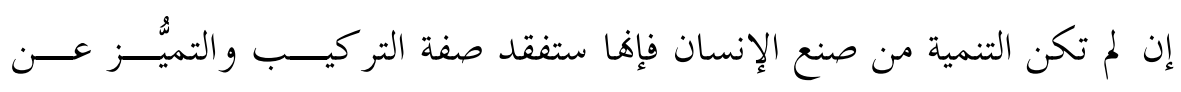

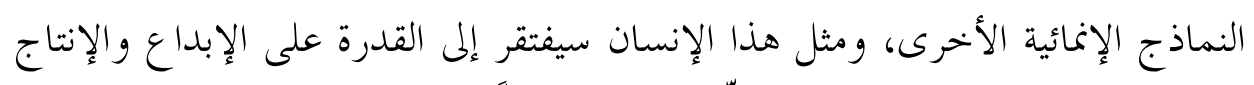

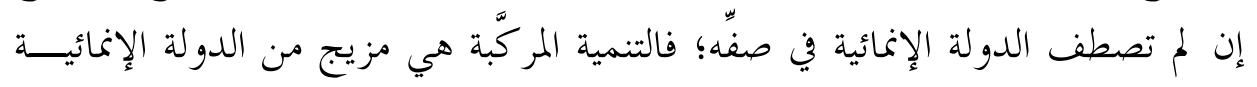

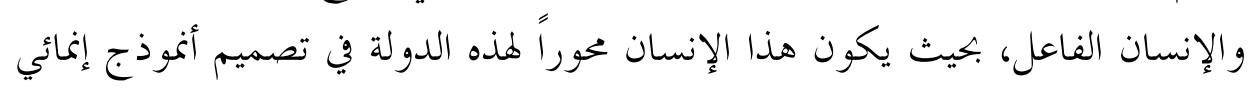
ناجح.

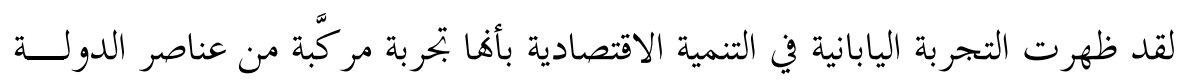

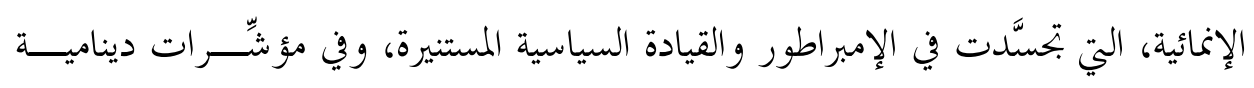

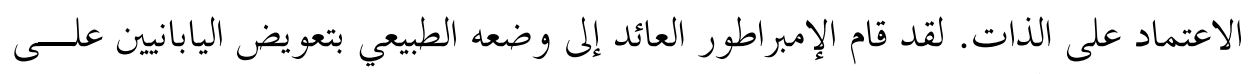

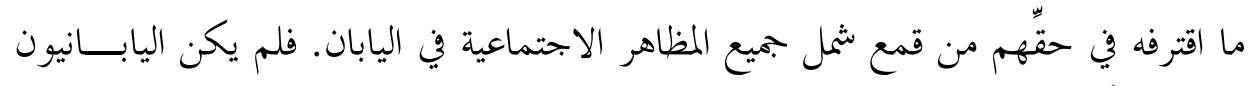

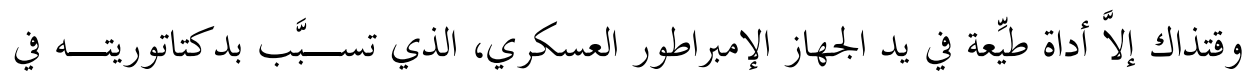

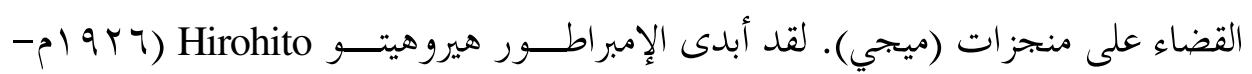

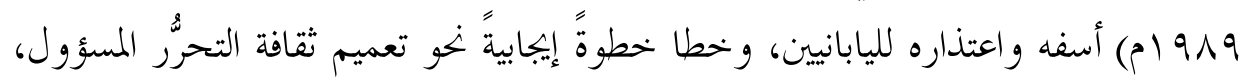
وطيّ صفحةٍ قديمةٍ في ثقافة القمع.

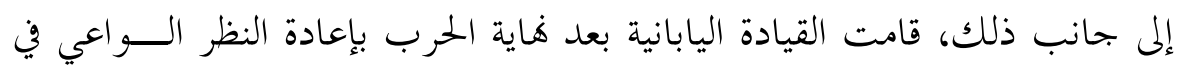

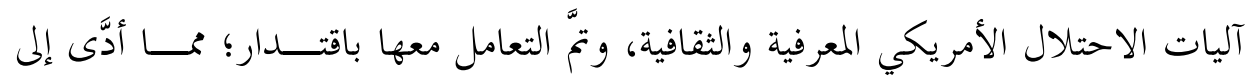

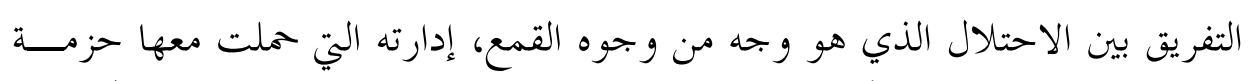

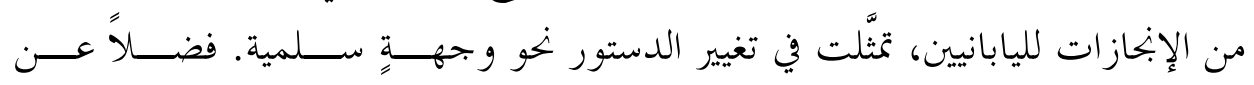

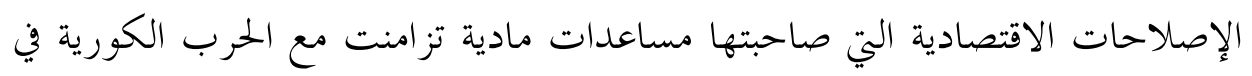




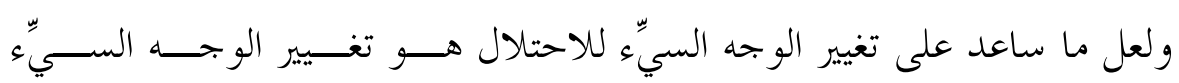

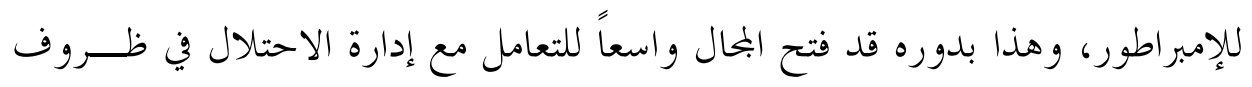

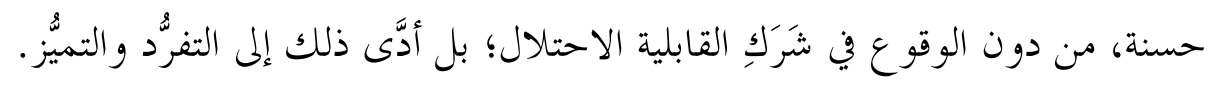
نخلص من هذه التغيُّرات البنيوية الحاصلة، إلى أن الدولة اليابانية قرَّرت أن تتحـــوَّل

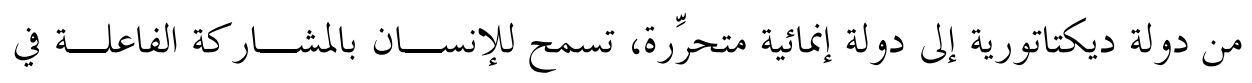

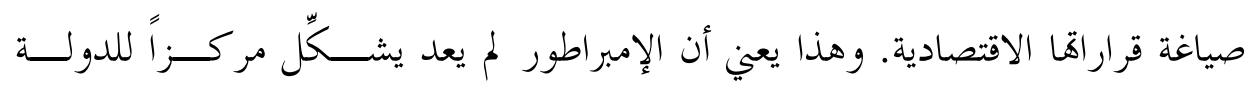

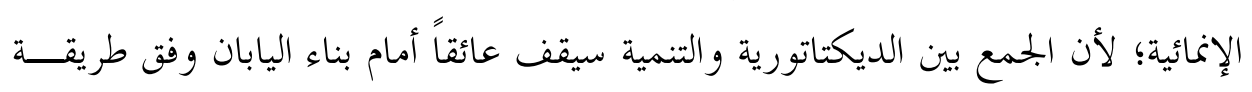

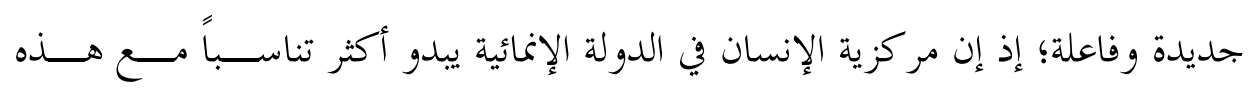

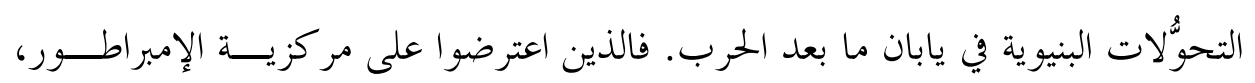
عدّوه إنساناً لا أكثر، بإمكانه أن يشارك إلى جانب اليابانيين في عملية البناء الاقتصادي، بادي،

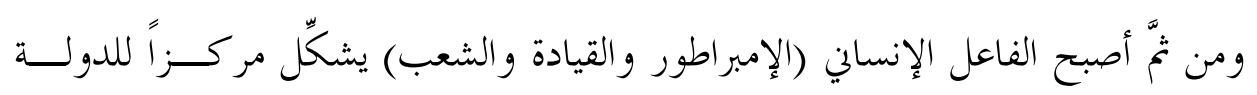

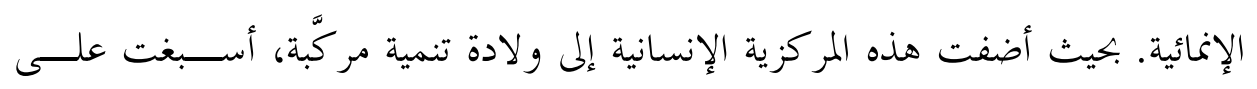
الاعتماد على الذات، دينامية فاعلة، فالاعتماد على الذات يفقد فاعليتـــه إن لم تســـبقه

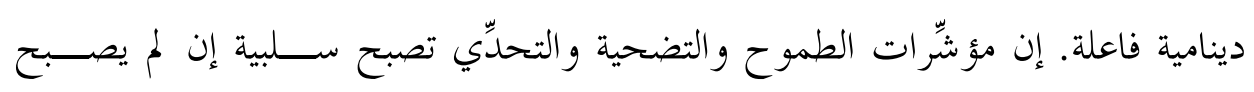

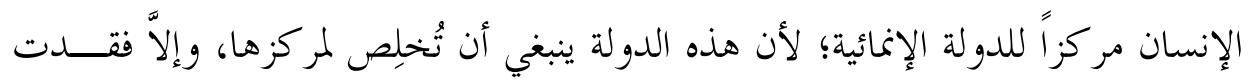
قدرة على الاستمرار.

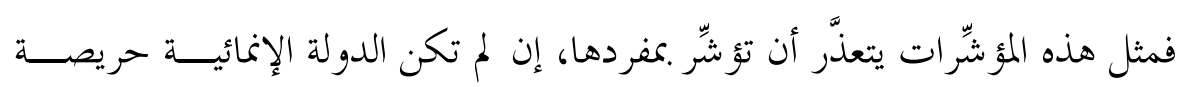

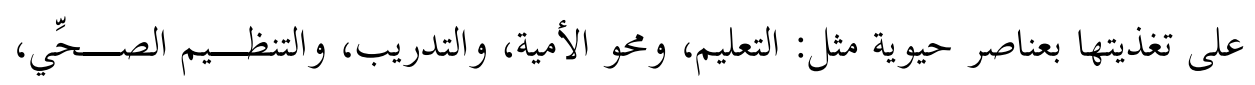
وإطلاق الحرِّيات العامة.

إن التجربة الإنمائية التي تقوم على عناصر مركَّة هي تجربة دينامية. فــإذا كـــان

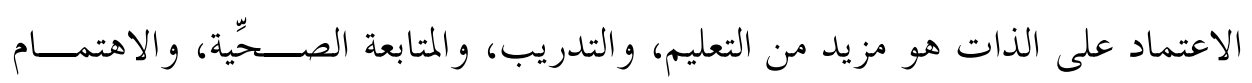

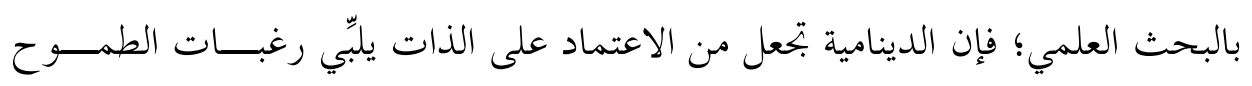




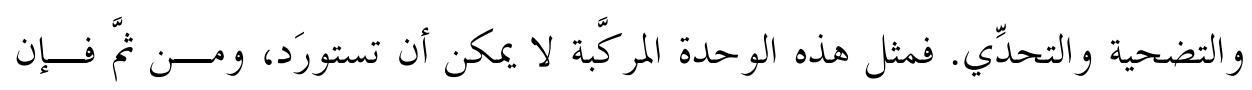

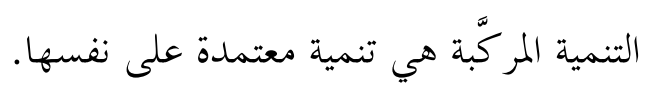

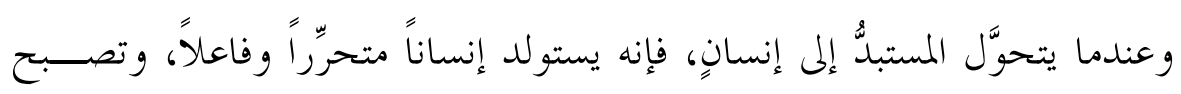

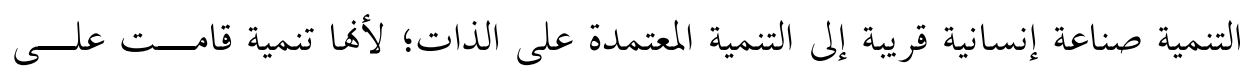
احترام الإنسان، وبالتالي هي تنمية مركَّة.

لقد قامت النمور الآسيوية، بوصفها أنموذجاً للتطوُّر باستفادة يابانية، على قاعدة

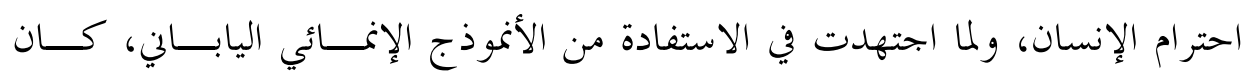

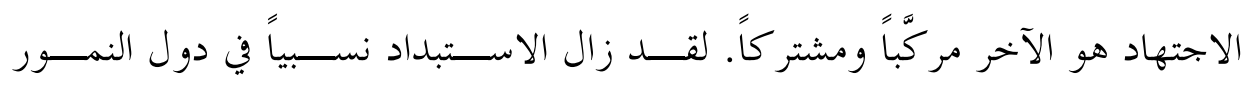

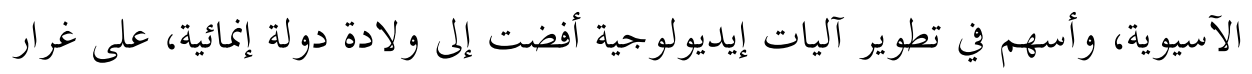

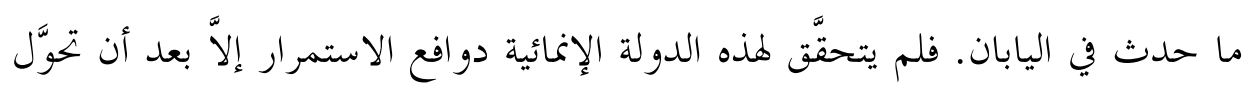

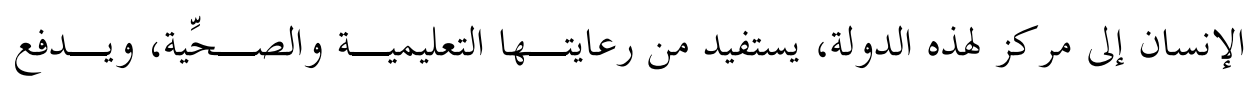

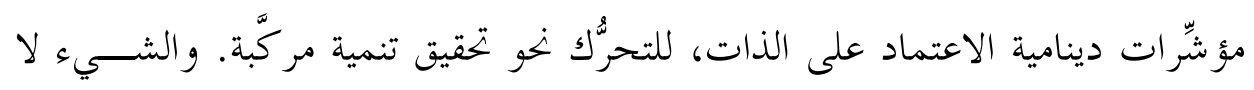

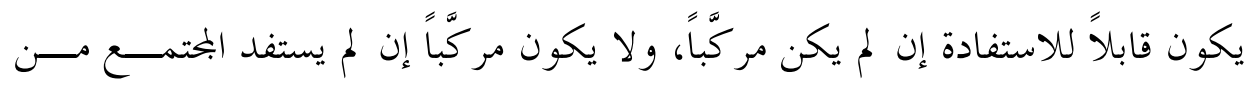
إبحاز اته.

لم يستفد الإنسان المسلم من الإنحازات التي صنعتها النماذج الإنمائية الغربية؛ لأفا

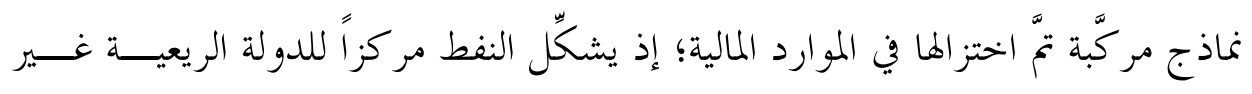

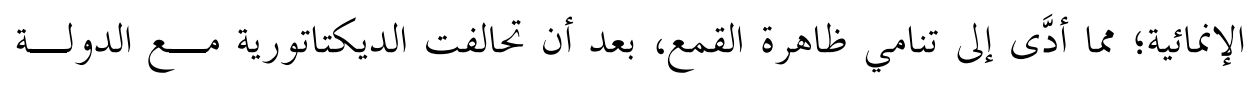
الريعية غير الإنمائية؛ لإقصاء الإنسان من المشار كة في عملية البناء الاقتصادي.

لقد قام الأنمودج الإنمائي الغربي على قاعدة احترام الإنسان، وتلبية مطالبه، وتنمية

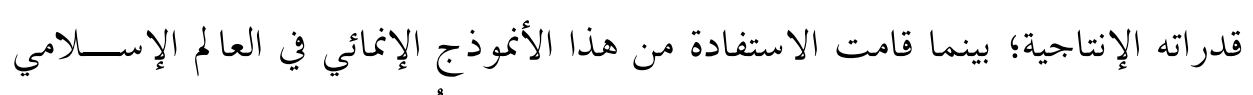

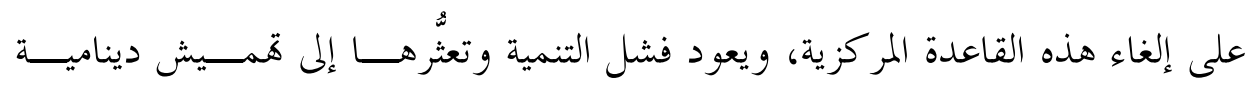




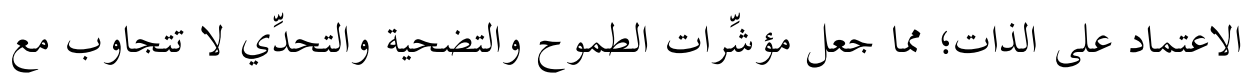

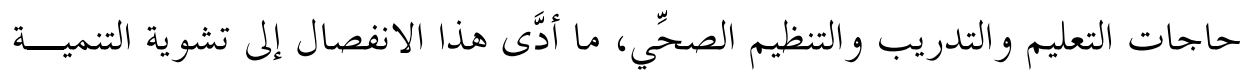

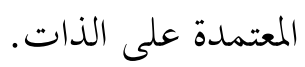

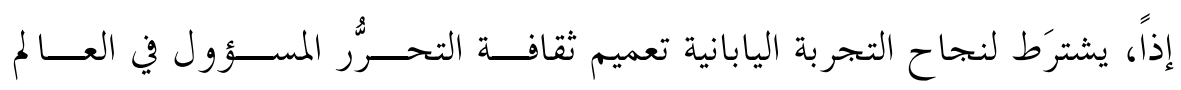

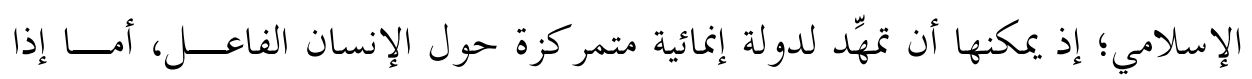

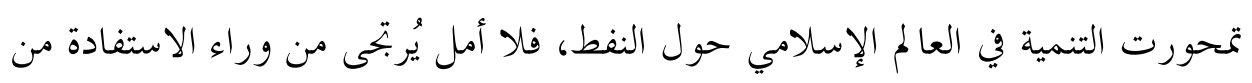

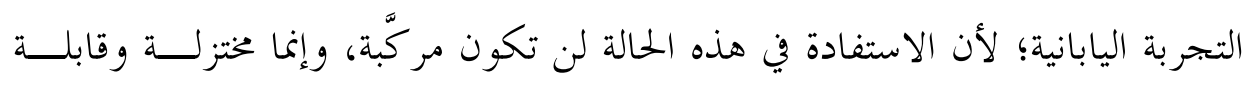

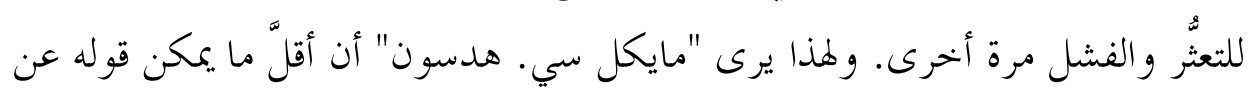

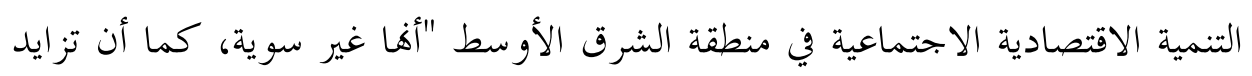

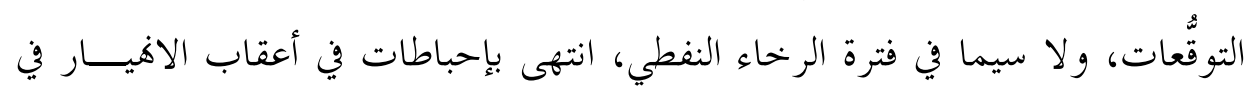

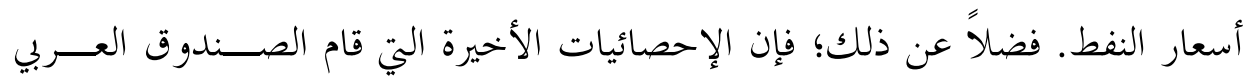

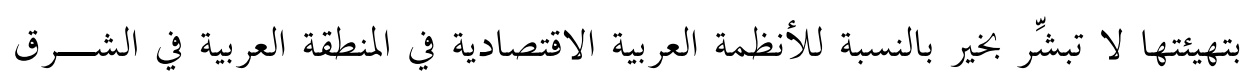

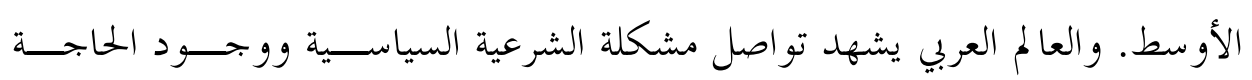

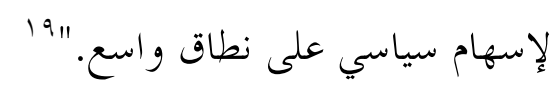

إن أهمَّ ما يمكن أن يستفيد منه العالم الإسلامي من اليابان، في ظــلِّل اســــر اتيجية

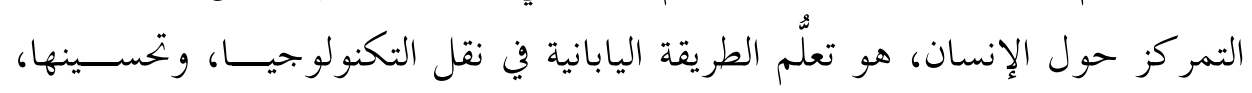
وتطو يرها، وهذه ميزة من صنع الإنسان. r.

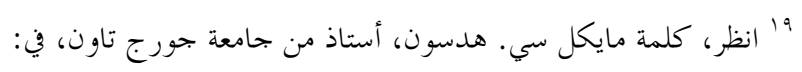

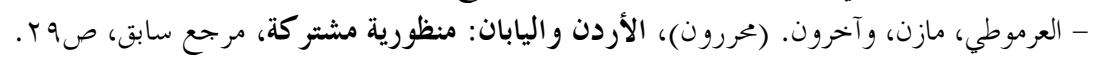

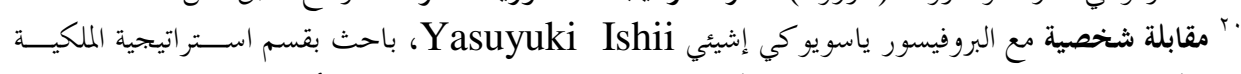

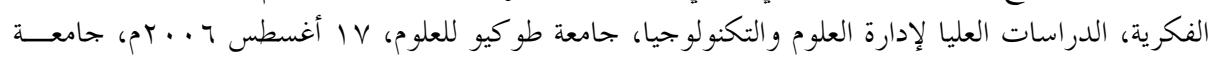

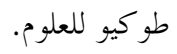




\section{ثالثاً: ملاحظات نقدية}

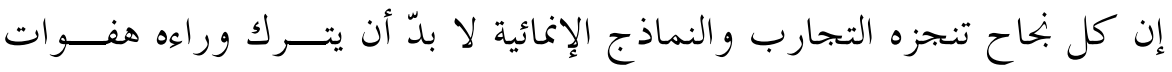

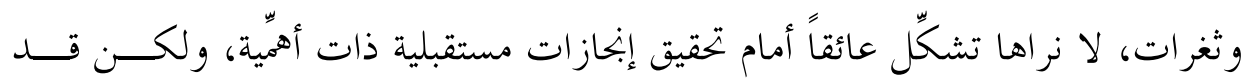

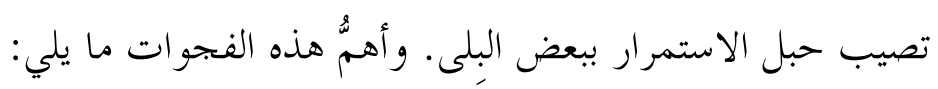
ا ـ يَّضح أن هناك وقتاً طويلاً أمام اليابان لتطوير أنموذج إنمائي بإمكانه أن يكون بديلاً

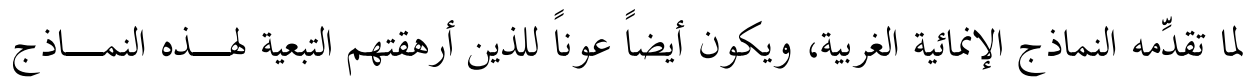

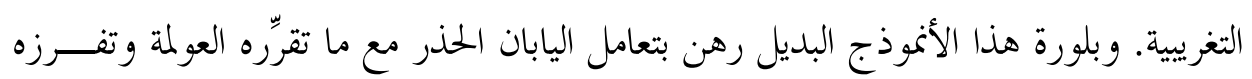

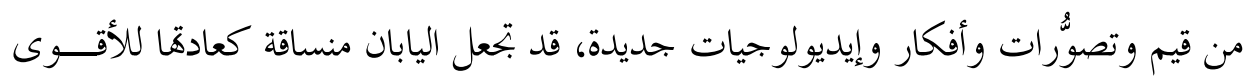

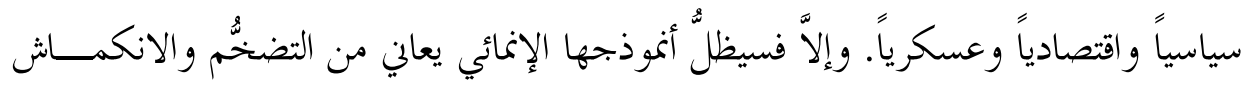
و الكساد و الإفلاس.

r. تحتاج اليابان إلى الإصلاحات الداخلية بشكل كبير، وفي هذا الصدد وضــع

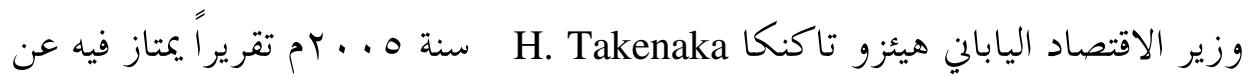

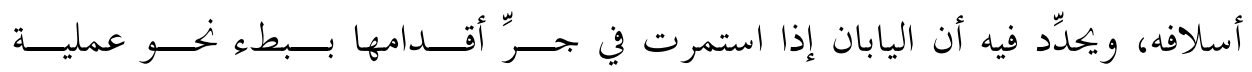

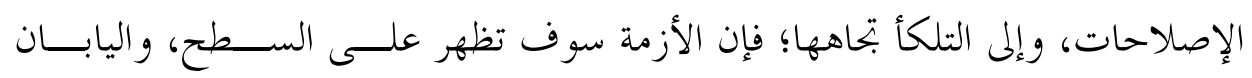

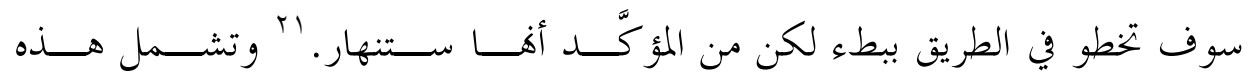
الإصلاحات: التنظيم الصناعي، و خفض الأسعار، و ونظام التعليم، وأساليب التوظيف. ب. هناك اختلاف جذري بين القيم اليابانية والقيم الإسلامية؛ مما قد يتعــَّر على العالم الإسلامي الاستفادة المركَّة من اليابان في بحال التنمية؛ لأن اليابان مقلِّدة

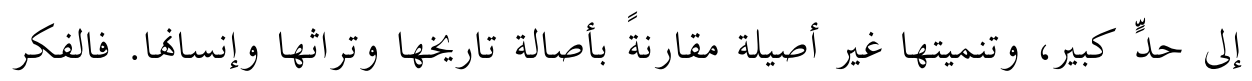

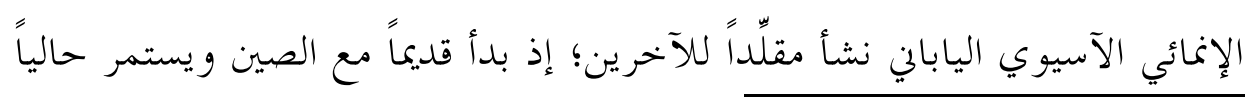

21 Cheok, Cheong Kee and Kah, Wong Choong. Asia Resurgent: Transformation Growth and Integration, Kuala Lumpur: University of Malaya Press, $1^{\text {st }}$ Ed, 2006, p288. 
مع الغرب، فهو فكر تابع يغلب عليه الحفظ والتلقين والترديد، ولا يمتلك المقـــدرة

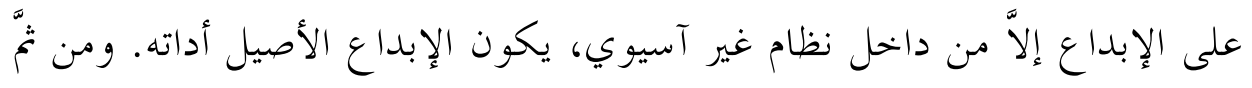

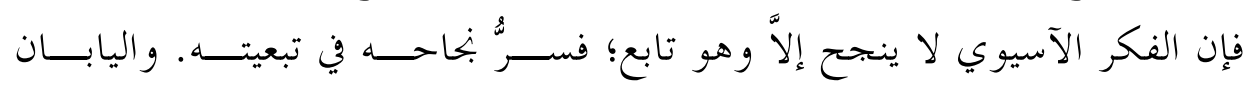

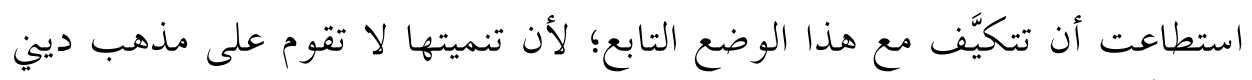

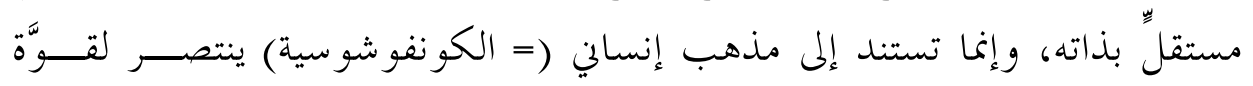

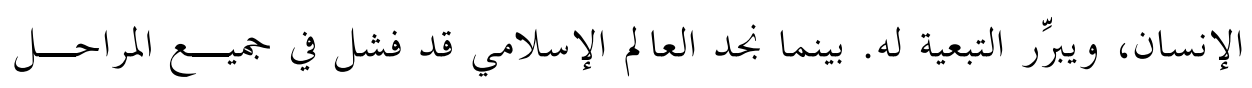

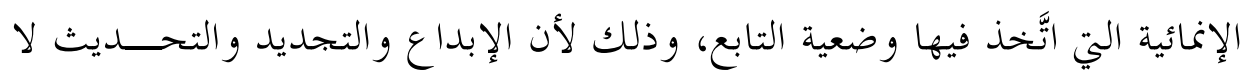

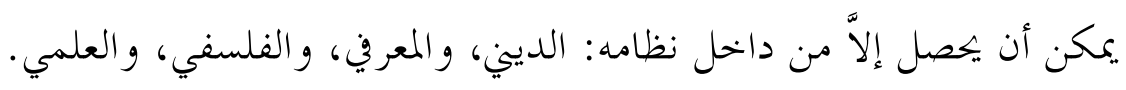

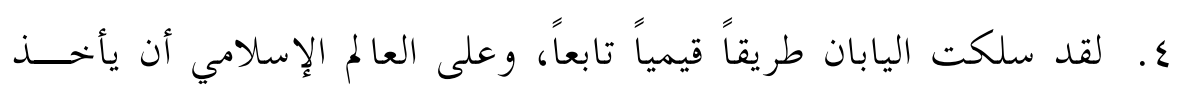

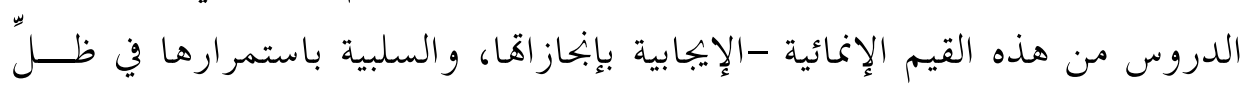

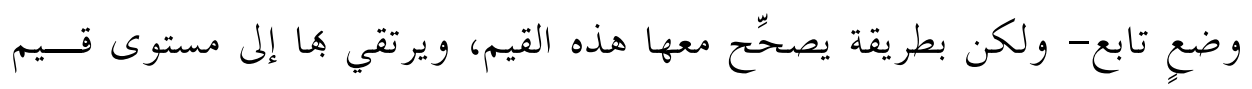

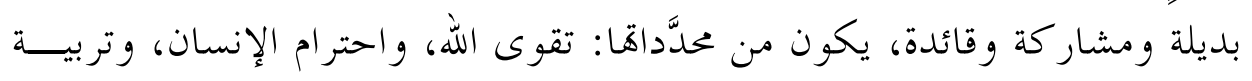

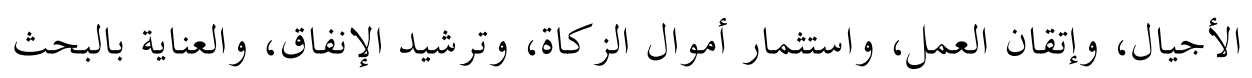
العلمي، وحيازة التكنولوجيا.

\section{رابعاً: اقتراحات إنمائية مر كَّة لعالم إسلامي مفكَّك}

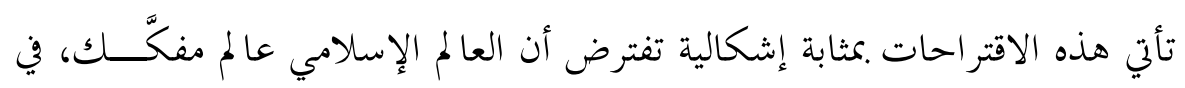

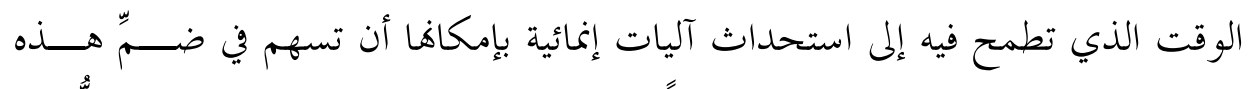

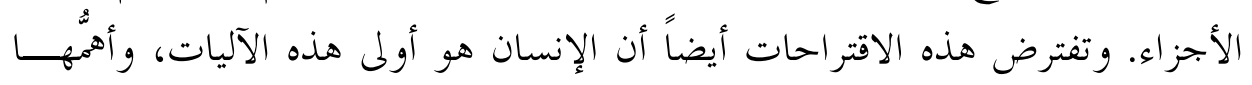

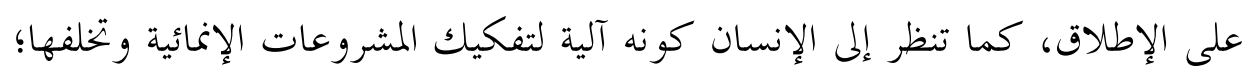

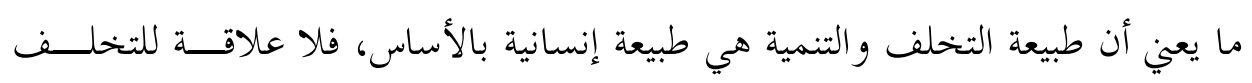

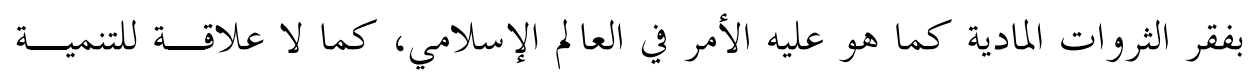

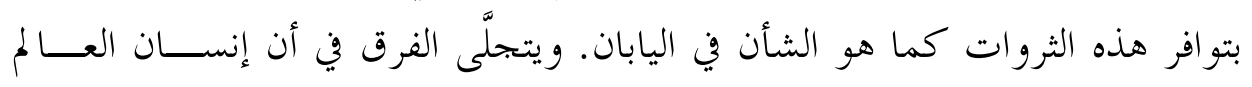


الإسلامي مفكَّك ويعمل ببطء؛ بينما إنسان اليابان مركَّب ويعمل بسرعة. ومن هنا،

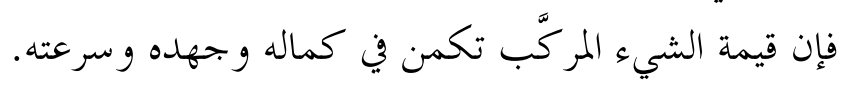

ا ـ المؤشِّرات السلبية ومأزق التنمية المركَّة في العالم الإســلامي (= التنميسـة المفصولة/ الضنك) المتكرات

تعتري الإنسان بحموعة من المؤشرات السلبية المفككة للمشروعات، والإنسان في العالم

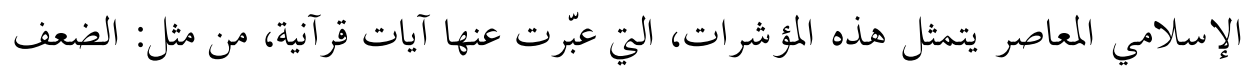

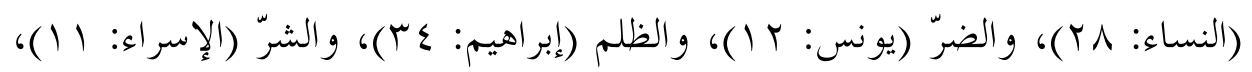

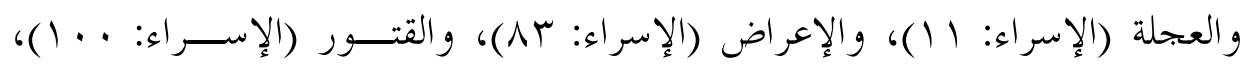

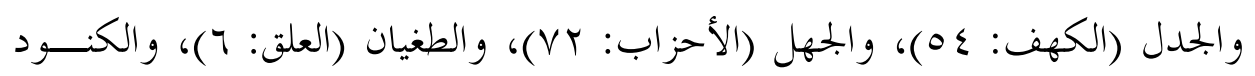

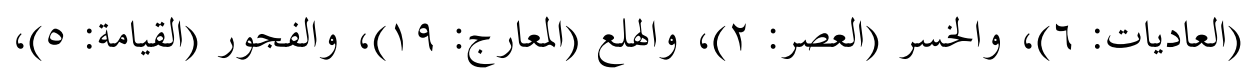
والغرور (الانفطار: (7).

ويتماهى الإنسان المسلم مع هذه المؤشِّرات السلبية، وينكسر بحاهها عندما يبلــغ ذروة

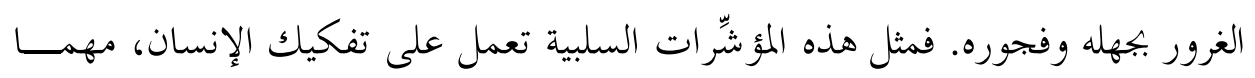

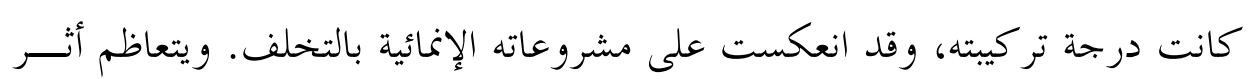

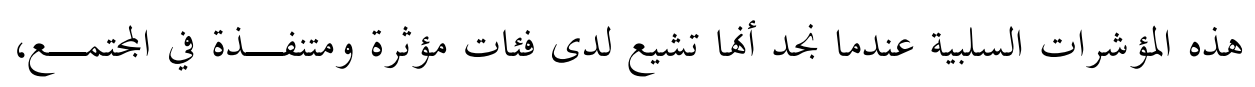

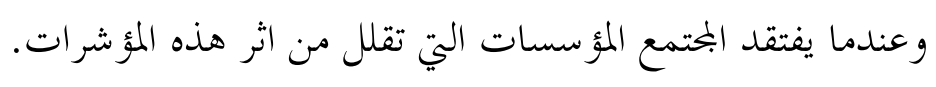

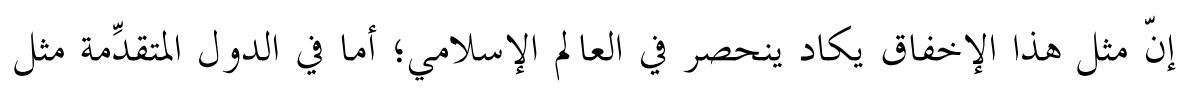

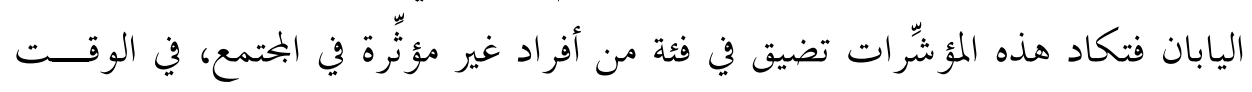

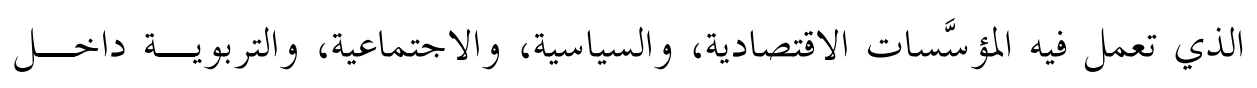
اليابان، على قطع السبل أمام التقارب بين الإنسان الياباني، وهذه المؤشِّرات التفكيكية.

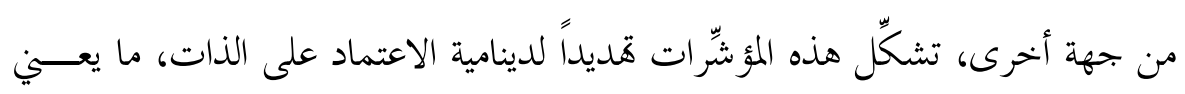

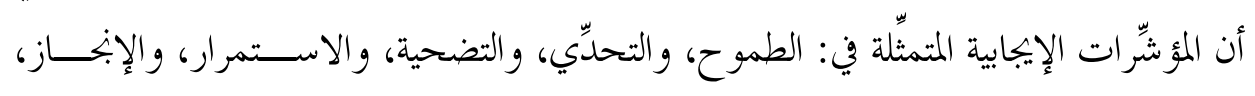


ستكون عديمة المحدوى، إذا اصطدمت هذه المؤشِّرات السلبية المخرِّبة للنسيج الإنمائي، وهــــا

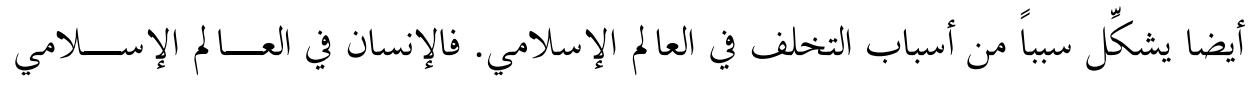

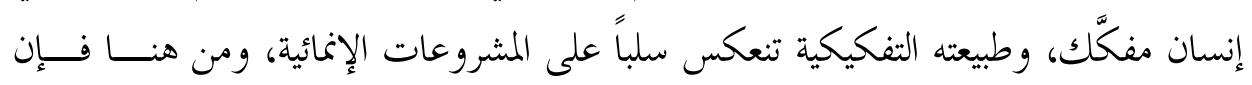

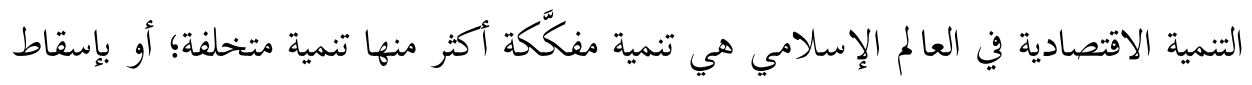

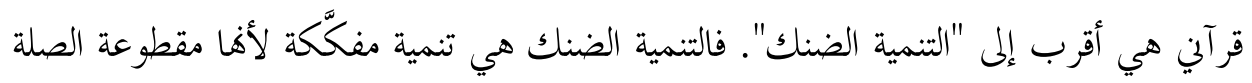

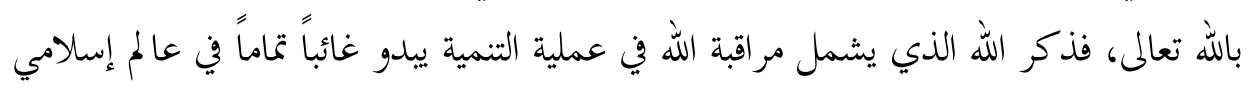

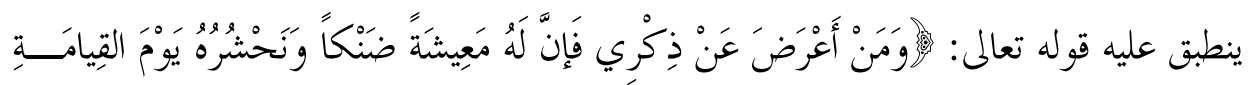

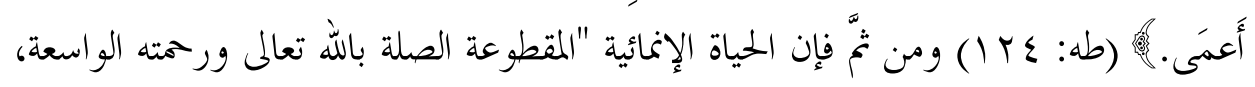

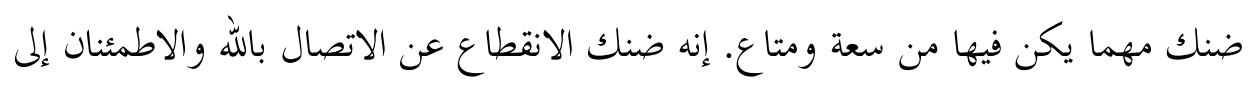

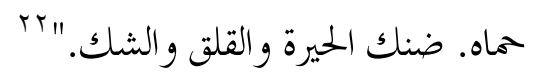

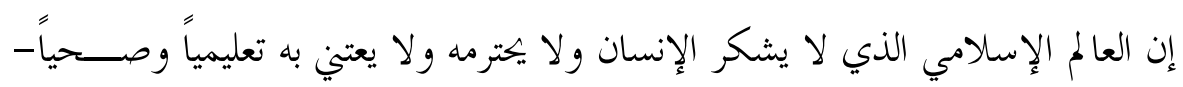

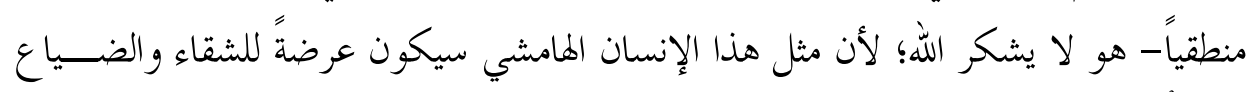

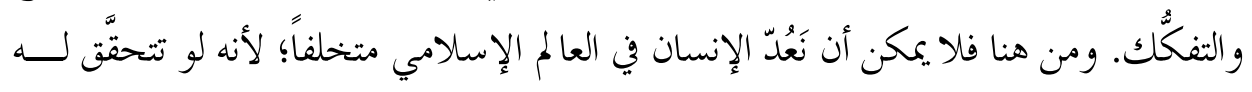

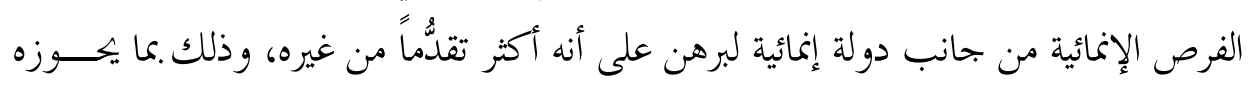
من إمكانات مادية وروحية.

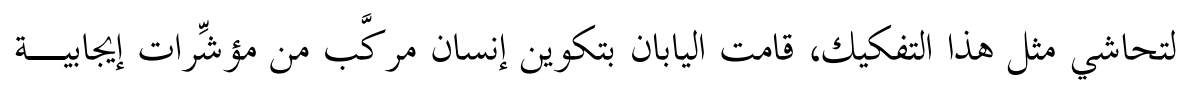

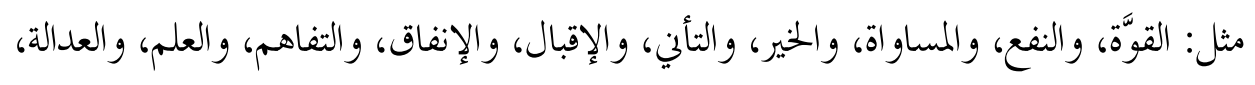

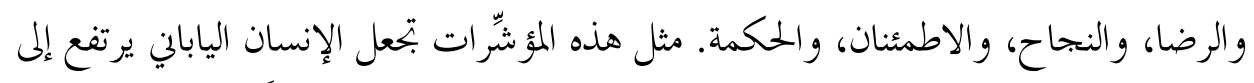

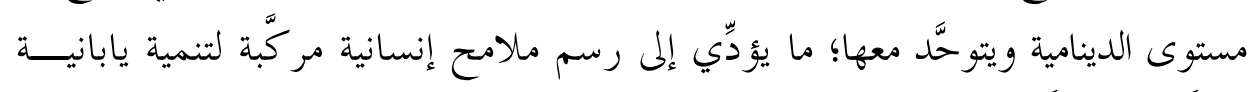

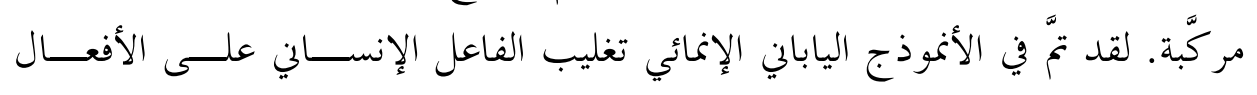

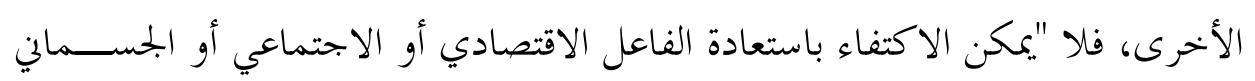

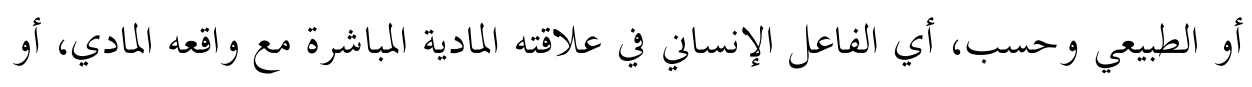




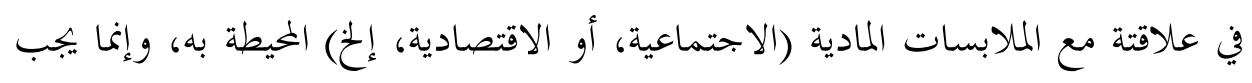

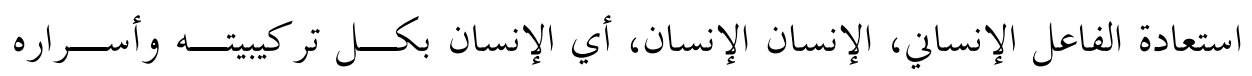
وفاعليته وإبداعه التي تجعله يتجاوز بيئته المادية الطبيعية المباشرة، وبتعل من العسير ردّه

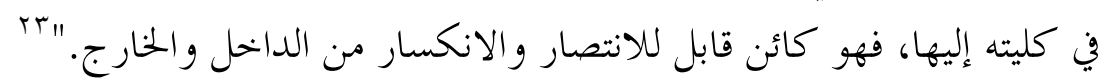

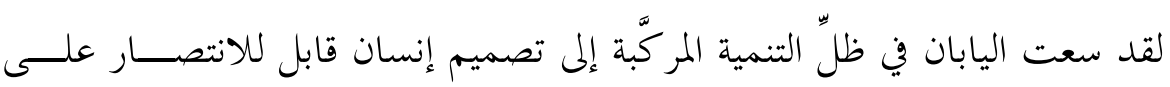

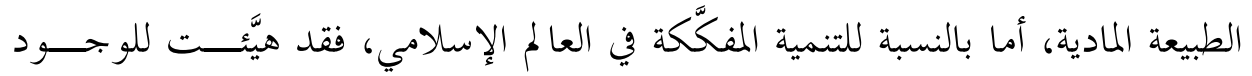

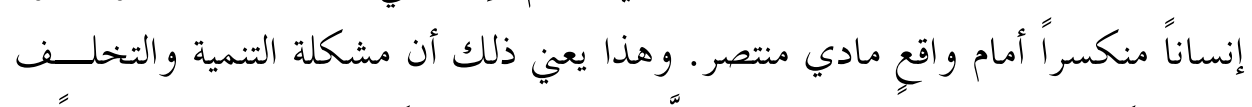

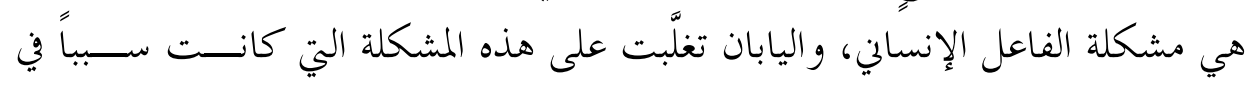
هزيمتها العسكرية.

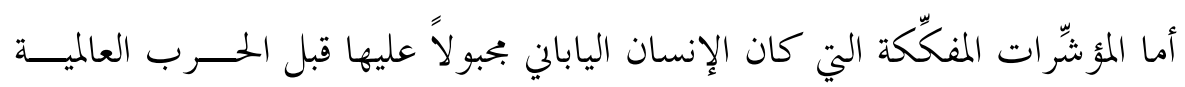

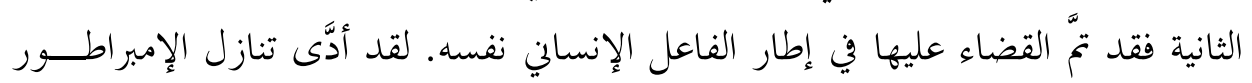

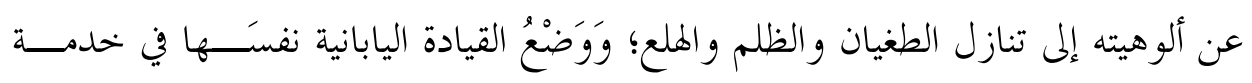

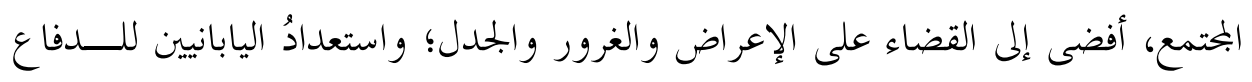

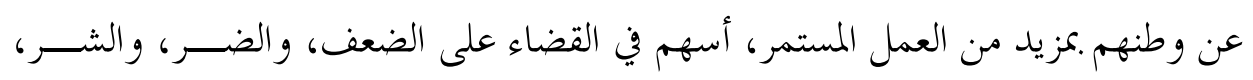

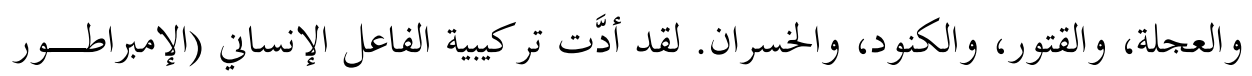

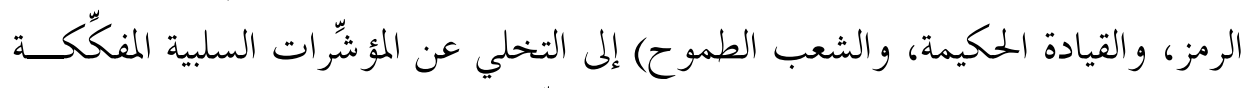

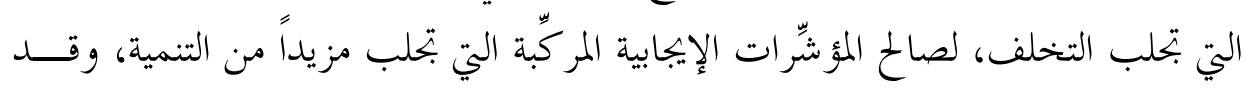

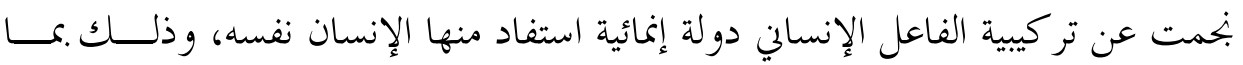

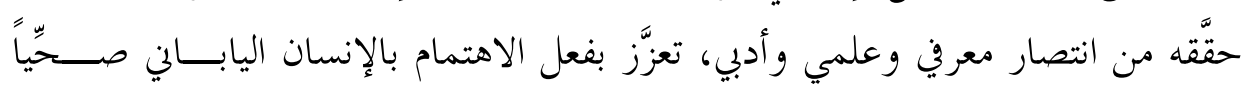
ومعنوياً ومادياً، ودفع بالتنمية إلى تحقيق مزيدٍ من وعني الإنسانية.

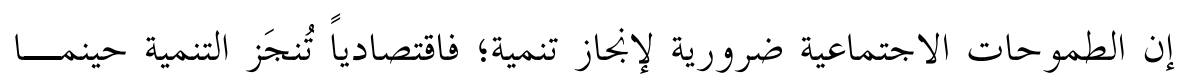

Tr المسيري، عبد الوهاب. دفاع عن الإنسان: دراسات نظرية وتطبيقية في النماذج المركَّة، القاهرة: دار الشــروق، طا،

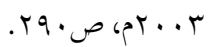


ترتفع الإنتاجية، ويكدح الناس من أجل زيادة إنتاجهم، وعندما ترتفع دخول الفــــد،

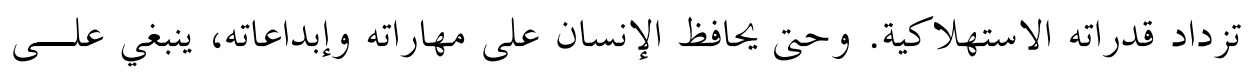

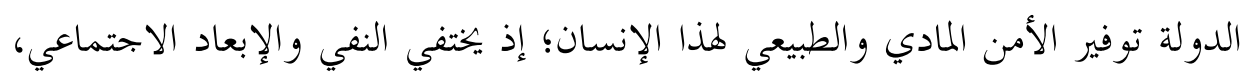

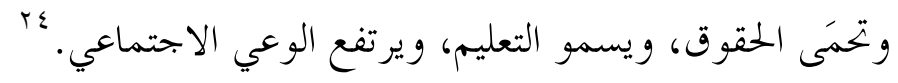

\section{Y. التنمية المركَّة فلسفة في الحياة (= التنمية الموصولة/ المنجزة)}

لقد تعامل اليابانيون مع التنمية بوصفها فلسفةً في الحياة ينبغي الدفاع عنها والقتال

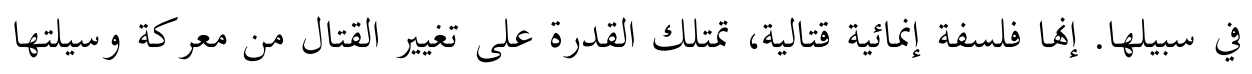

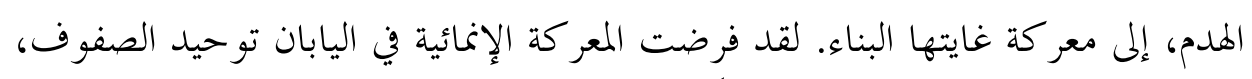

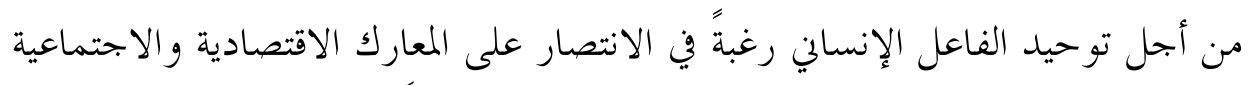

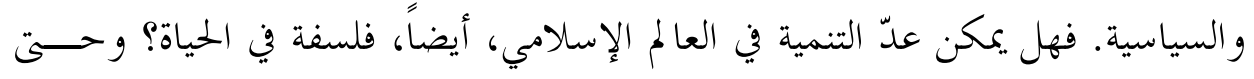

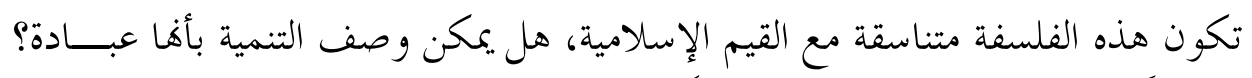

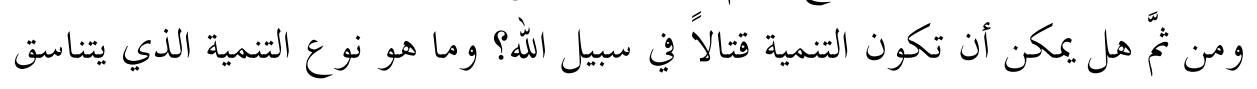

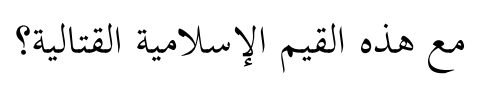

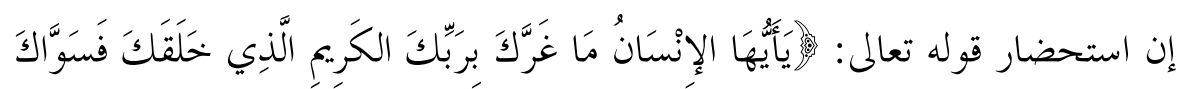

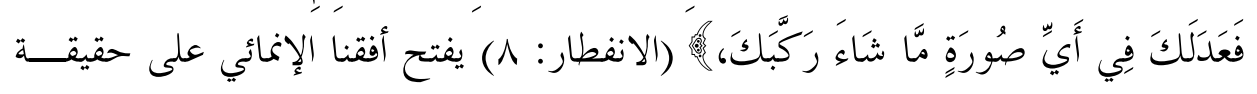

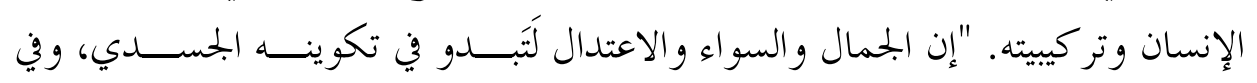

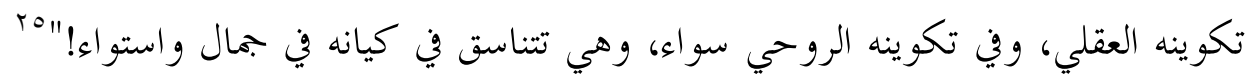

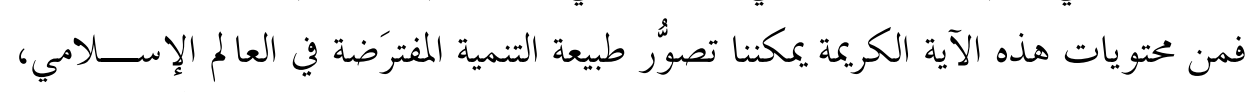

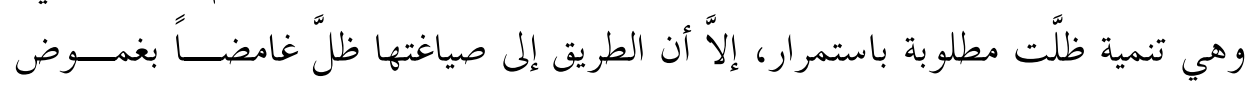
فلسفة الحياة، التي تفتقر إلى المنهاج الرباني السوي.

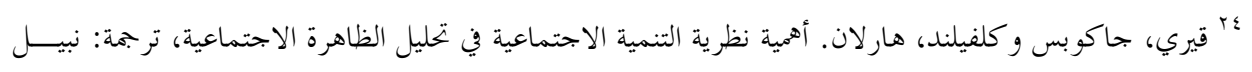

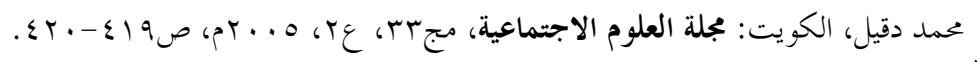

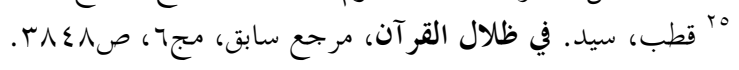


الإنسان الديكتاتوري لا يُنجز تنمية أبداً، والإنسان الذي يتعاطى مع الديكتاتوريسـة

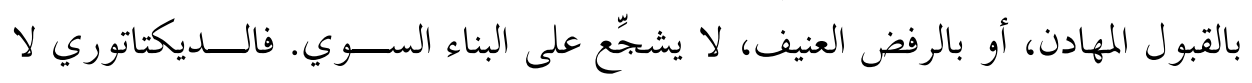

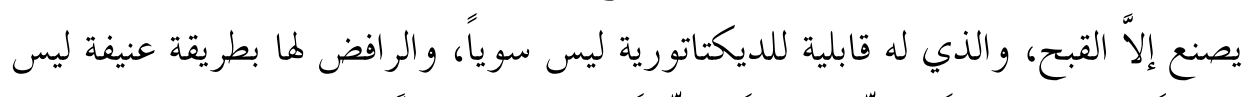

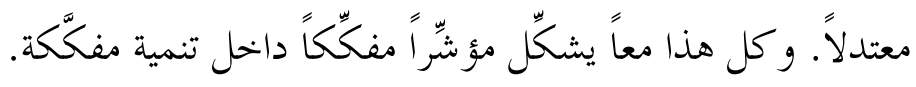

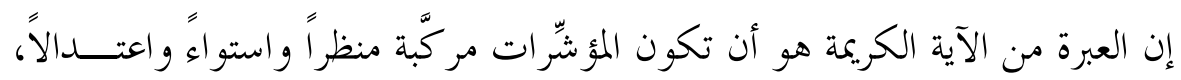

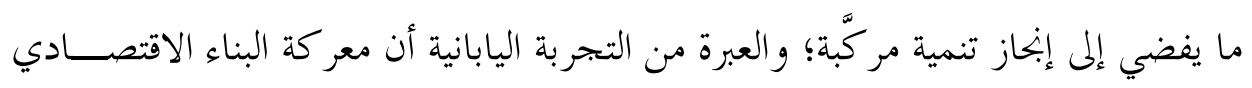

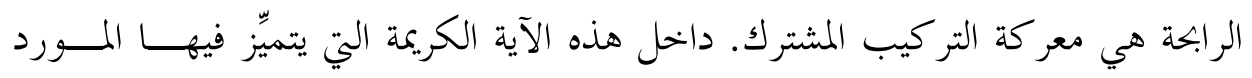

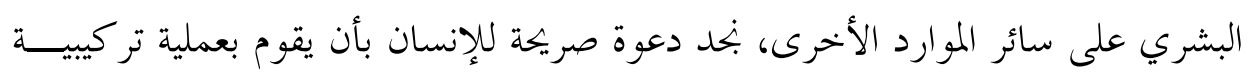

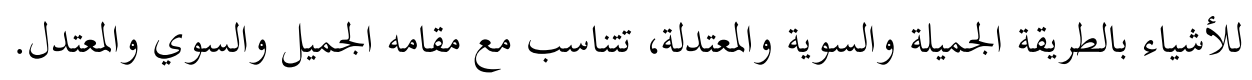

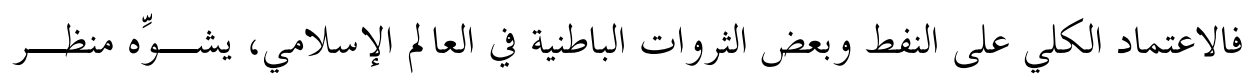
التنمية ويفكّكها؛ ما ييجعلها بعيدة عن تحقيق الإنحاز وتفعيل الاستمرار.

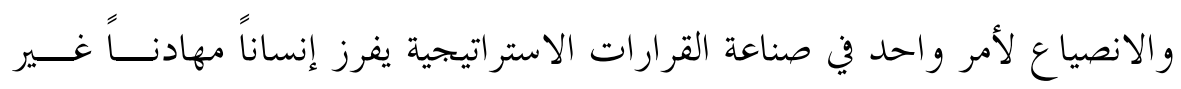

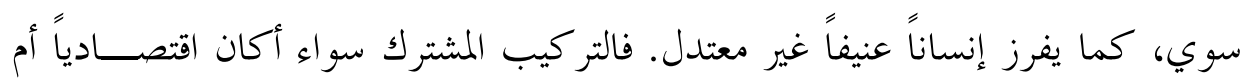

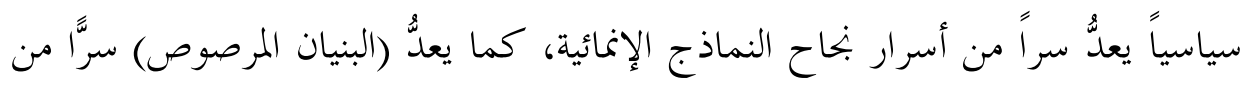

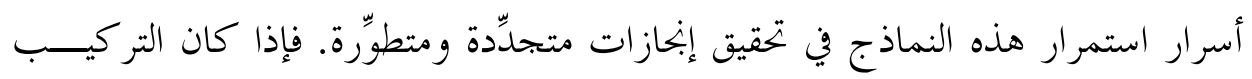

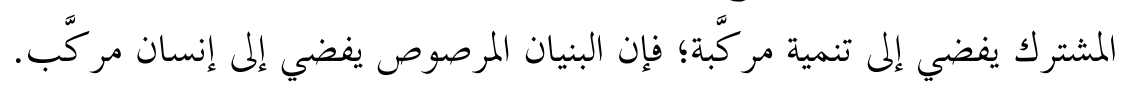

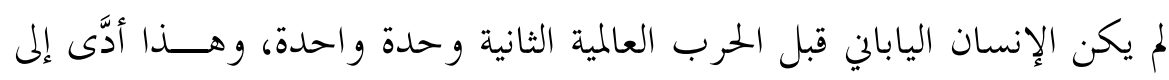

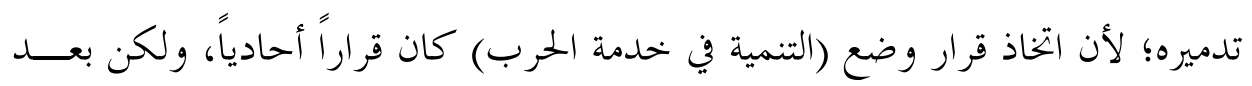

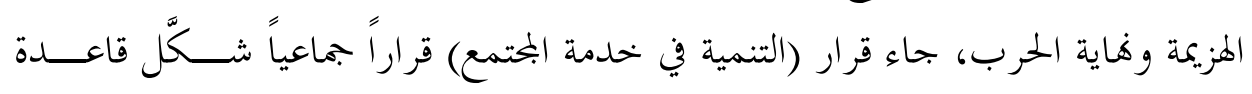

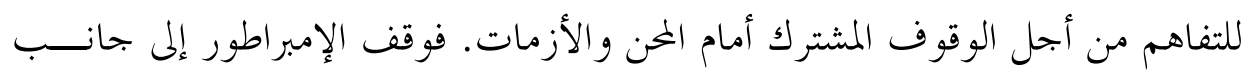

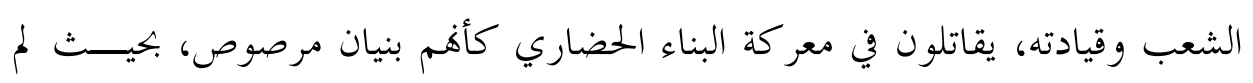

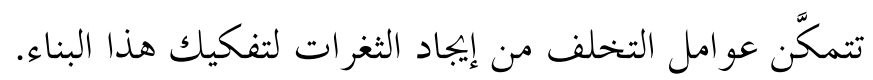




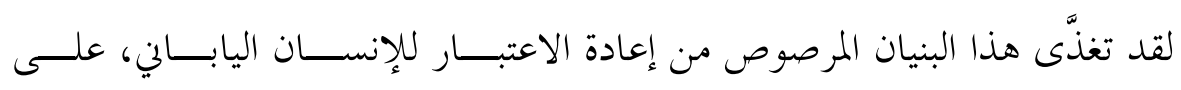

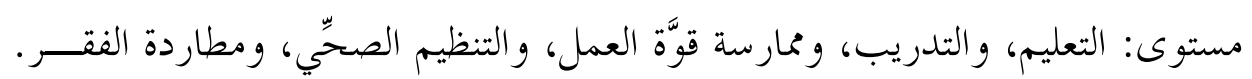

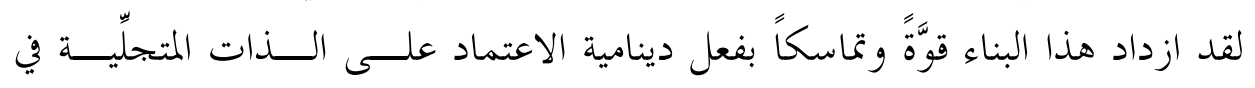

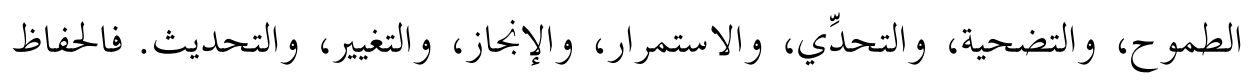

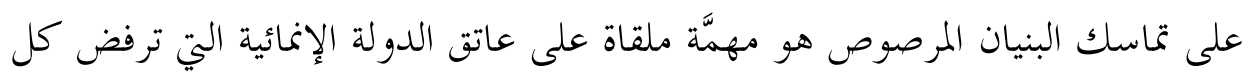

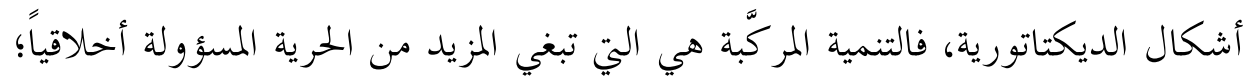

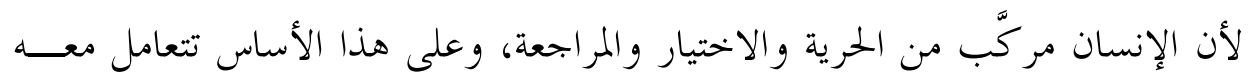

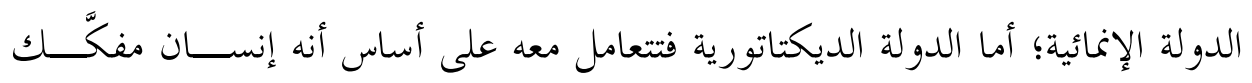

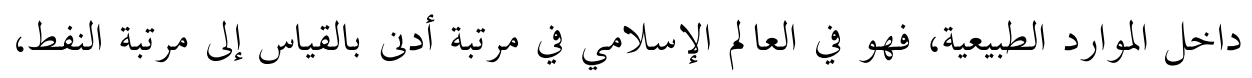

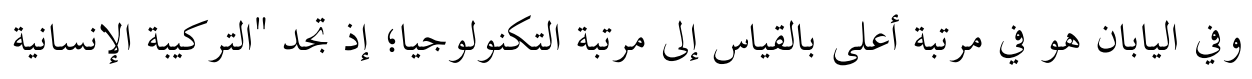

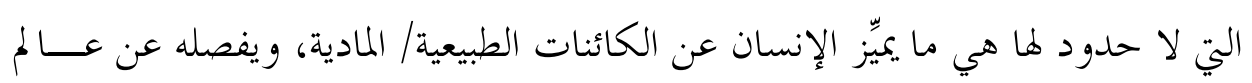

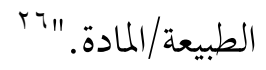

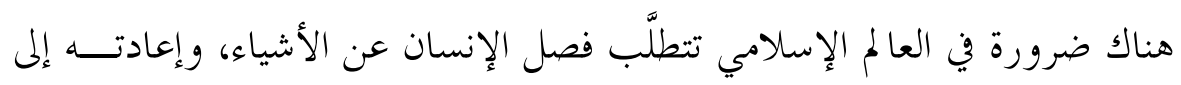

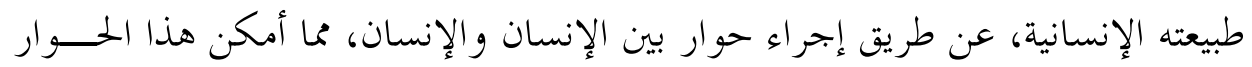

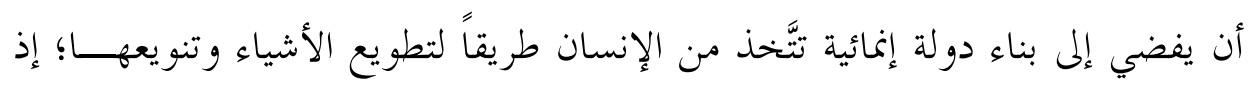
تعَدُّ التكنولو جيا -التي هي ميزة مقارنة من صنع الإنسان- أصلَ الأشياء.

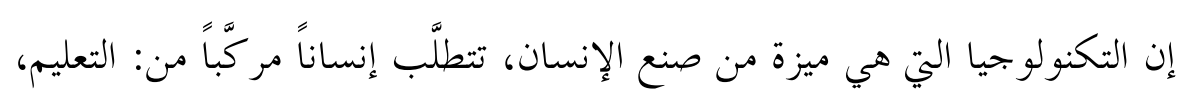

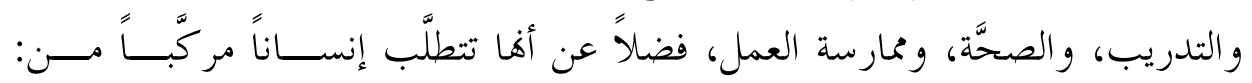

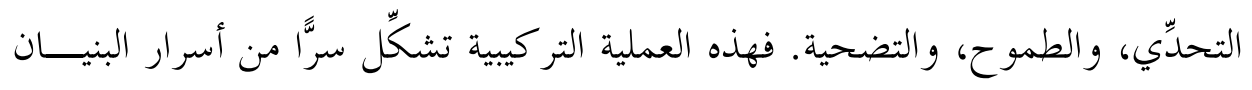

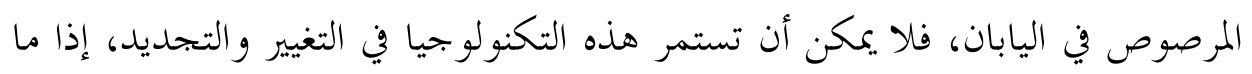

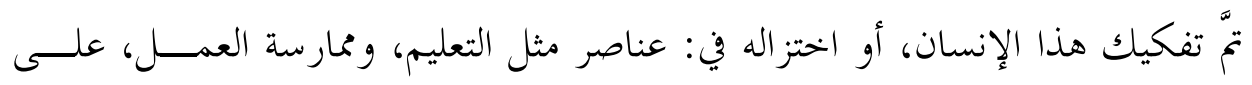


حساب الرعاية الصحِّة، ومحاربة الفقر، كما لا يمكن اختز اله في: الطموح، و التضحية، و التحدِّي، على حساب الاستمرار، والإبحاز، والتغيير.

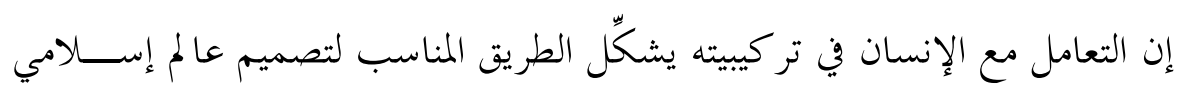

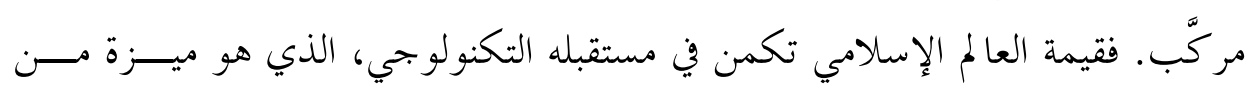

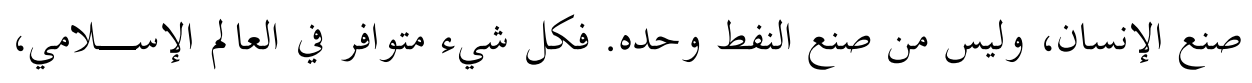

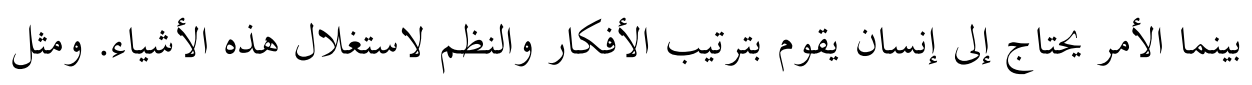

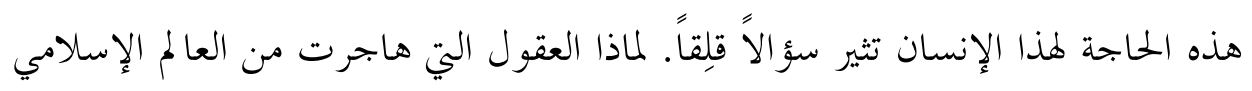

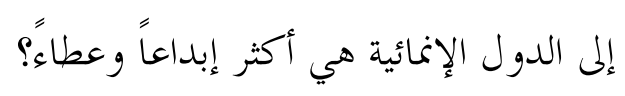

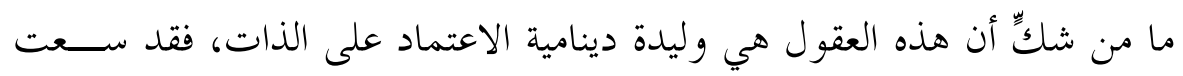

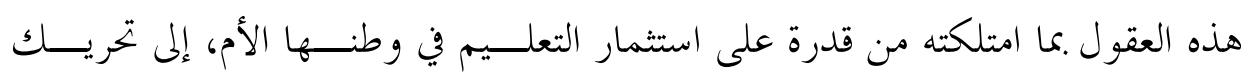

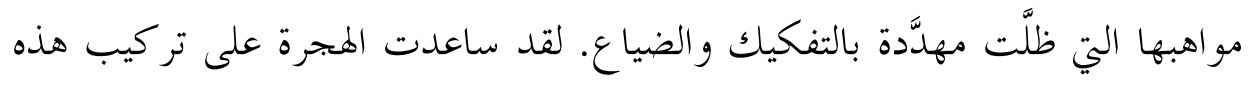

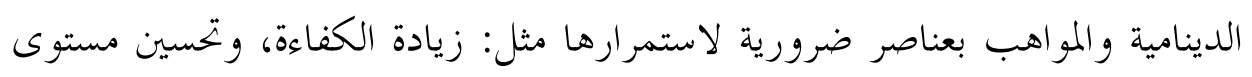

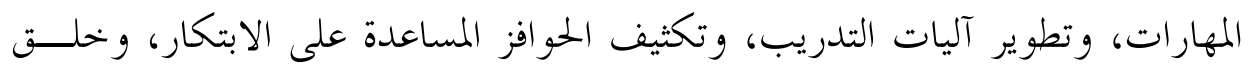
وضع صحِّي يسمح باستمرار نمو الإنتاجية.

لقد هاجرت العقول مفكَّكة وعاطلة، واستقرَّت في الدول الإنمائية مركَّة وفاعلة؛

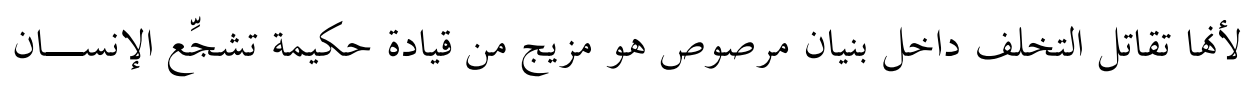

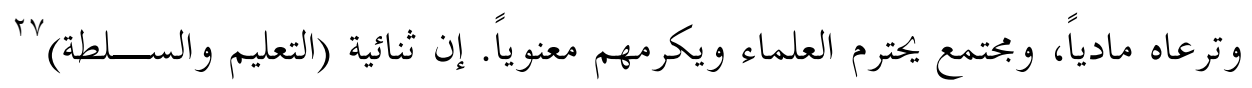

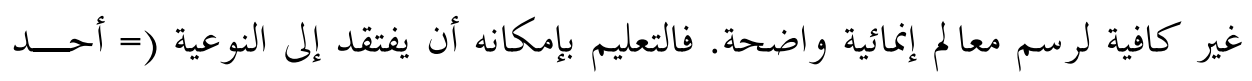

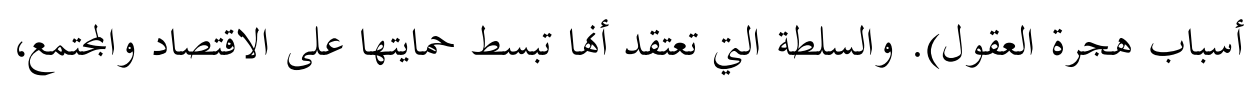

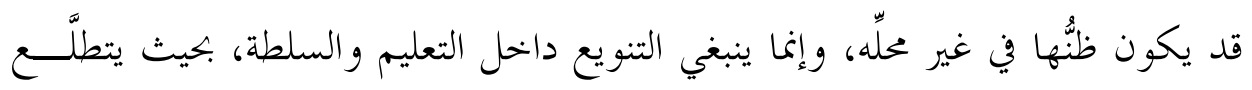

${ }^{27}$ Brainerd, William, and Peryy, George. Brookings papers on Economic Activi, (Washington, D.C: Brookings B Institution, 2005, p151 
المتعلِّم إلى صناعة الأفضل، وذلك إذا ما تصادف مع سلطة متنوِّة في عرض الحخيارات

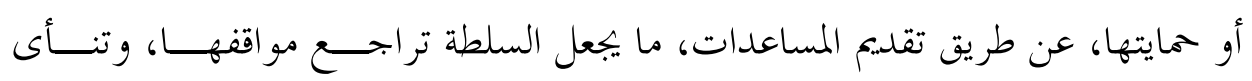
بنفسها عن الاصطدام مع إنسان متعلِّم تعليماً نوعياً.

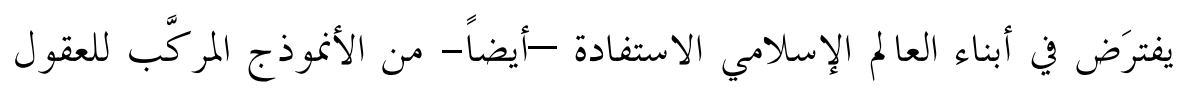

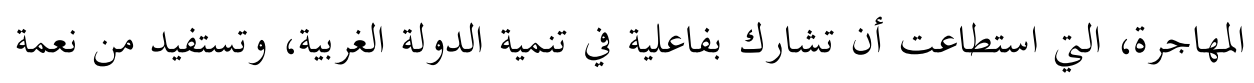

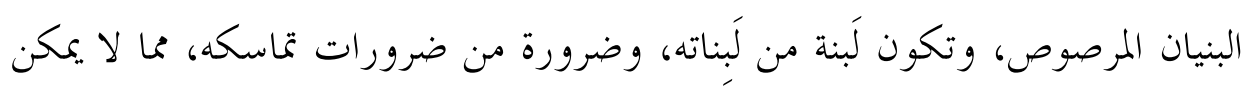

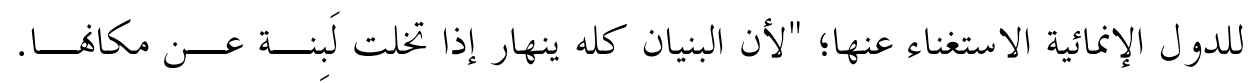

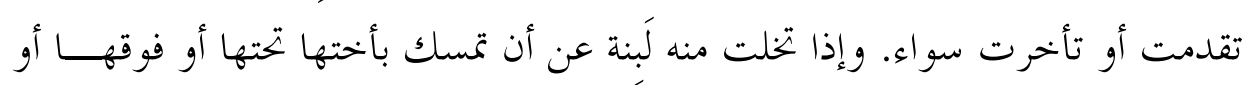

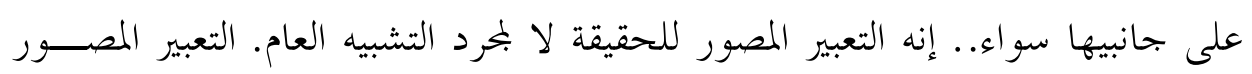

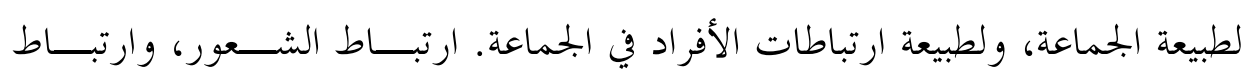

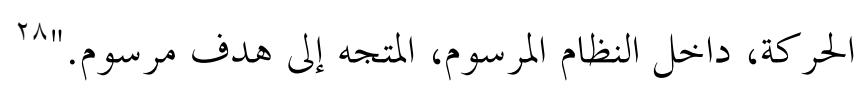

إن العبرة من هدف البنيان المرصوص هو ضرورة تأسيس دولـــة إنمائيسـة في

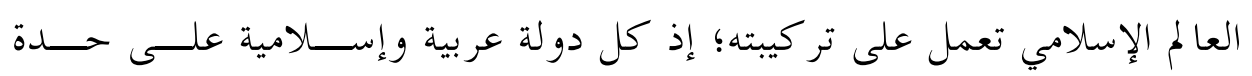

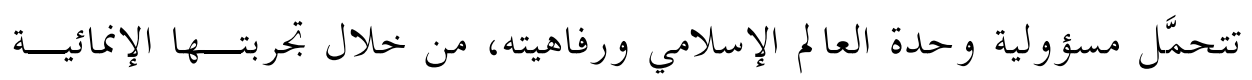

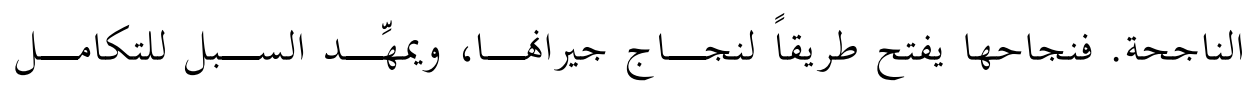

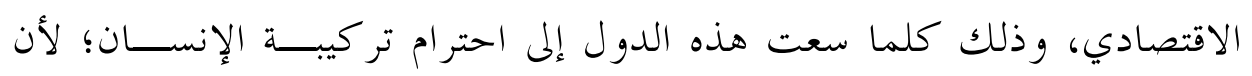

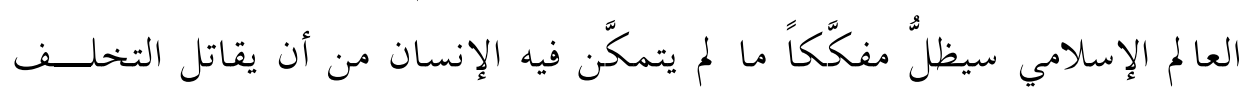

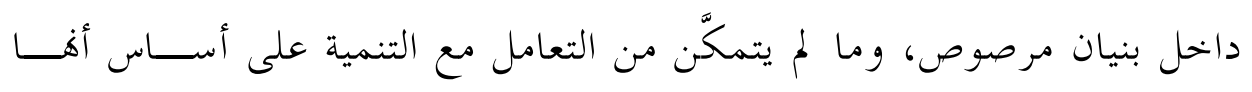

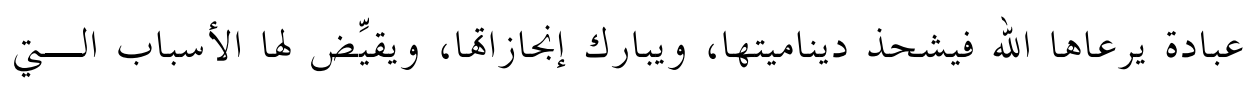

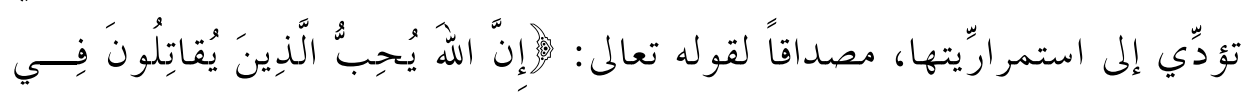




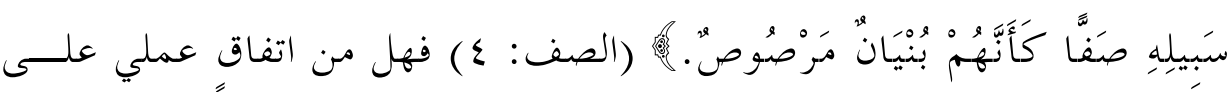

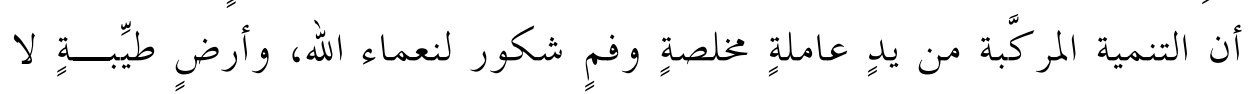

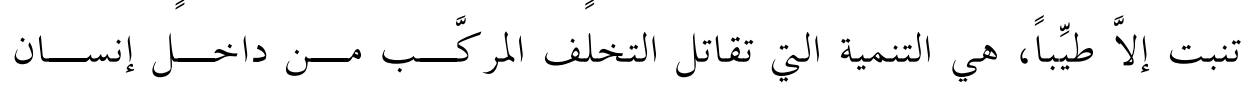

$$
\text { مرصوص؟ }
$$

\section{ب. التنمية المر كَّة بنيان مرصوص (= التنمية المرصوصة/ المستمِِّّة)}

لم تختزَل الاستفادة من عائدات التنمية اليابانية في جوانبها المادية، و وإنـــا

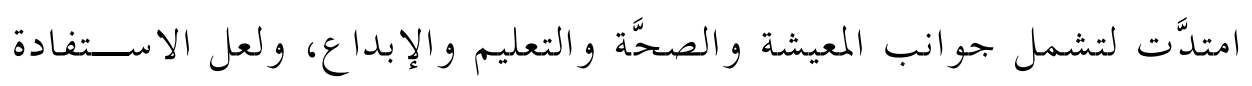

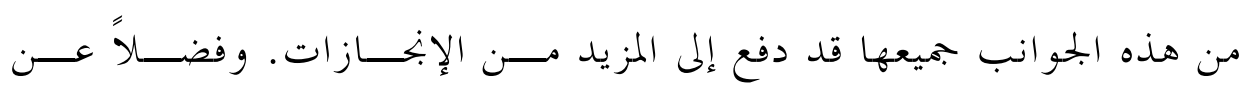

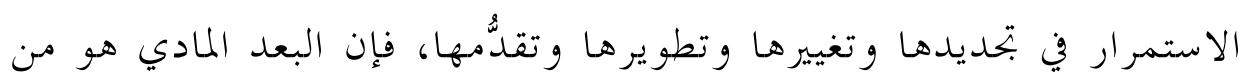

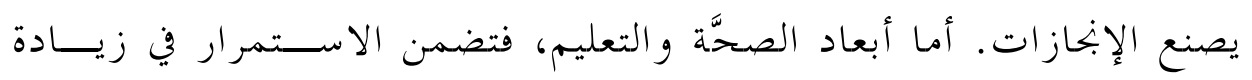

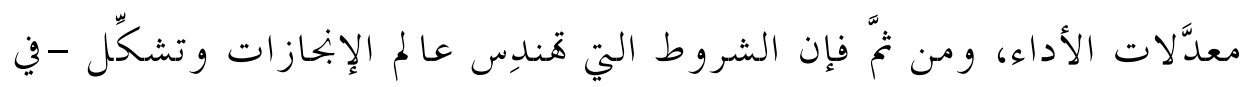
الوقت نفسه- الحافز على الاستمرارية في تحقيق الإنجازات، هي التي يفترَض الوقوف على أبعادها، قصدَ استخلاص الدروس و العبر.

لقد بذل اليابانيون بجهودات مستمرة في ممارسة العمل، و كانت القناعــة

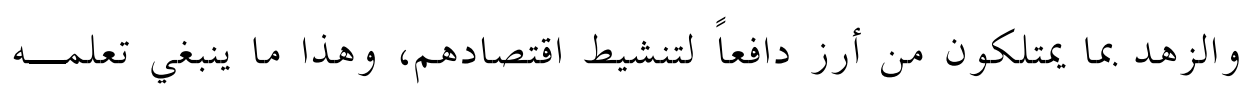

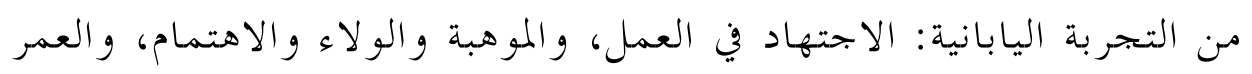

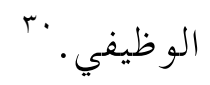

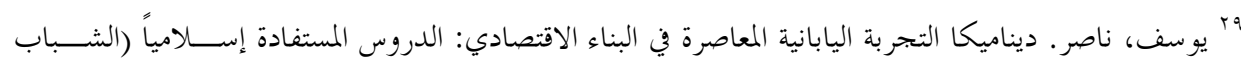

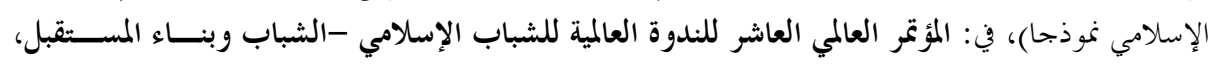

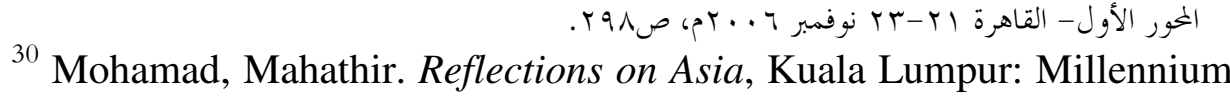
Books, p122. 


\section{أ. القدوة الخرِّة (= تو جيه فعل الرمز):}

كان للرمز في اليابان دور سيميائي استراتيجي في عملية بناء المســتقبل الاقتصــادي.

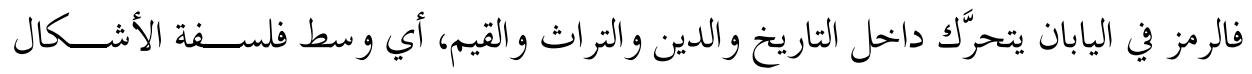

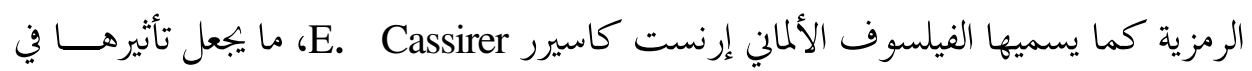

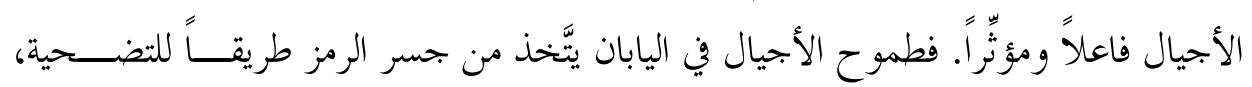

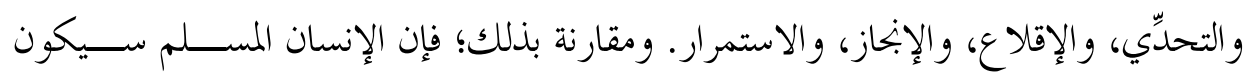

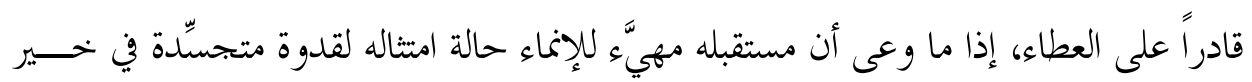

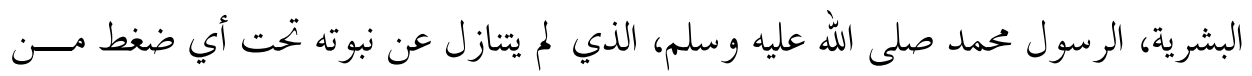
الضغوط.

إن اتخاذ الرسول صلى الله عليه وسلم قدوة لإنسان يفترَض أن يتحقَّق عملياً، علــى مستوى البناء المركَّب، فلا يمكن اختز ال الاقتداء به صلى الله عليه وسلم في جانب إنمائي

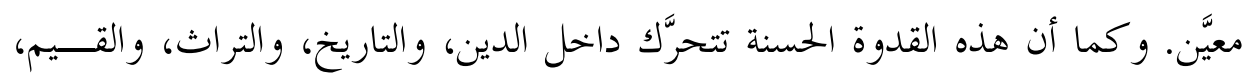

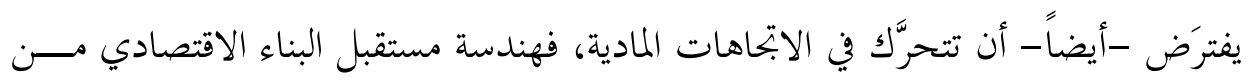

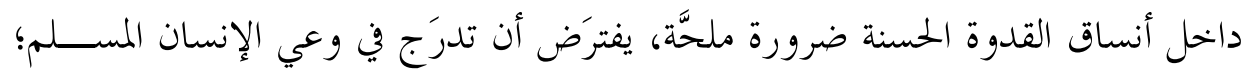

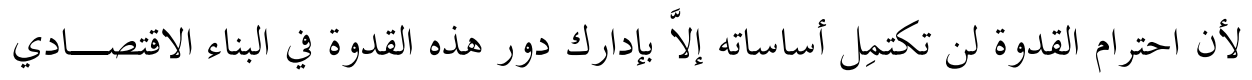
والاجتماعي، ويكتمل هذا الوعي كلما شعر الإنسان المسلم أن هذه القدوة قد أصبحت له بمثابة المحفّز الكبير لطاقاته الفردية والجماعية؛ بينما اختزالها في أمور دينية بحتة سيؤدِّي

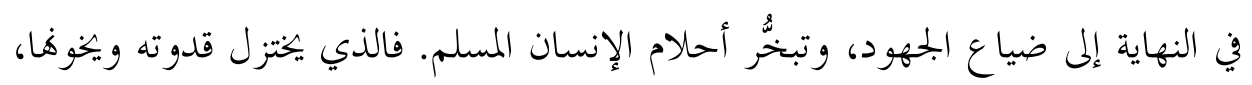

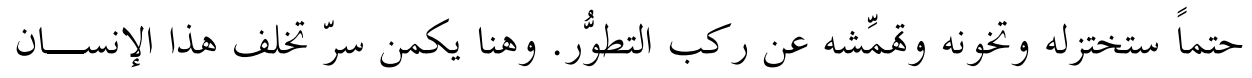
عن قطار التنمية و البناء الحضاري.

L'Empire des بعد عودة رولان بارت من زيارة لليابان كتب كتاباً بعنوان: إمبراطوريسـة العلامــات 


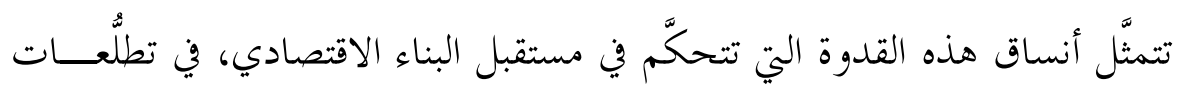

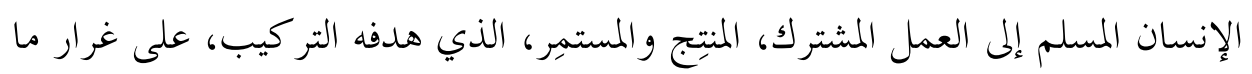

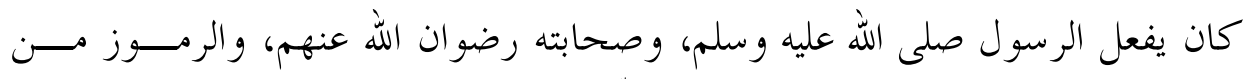

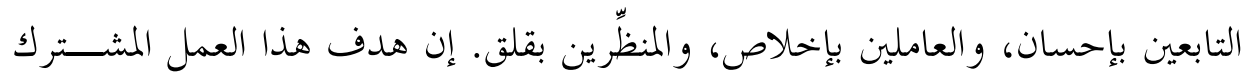

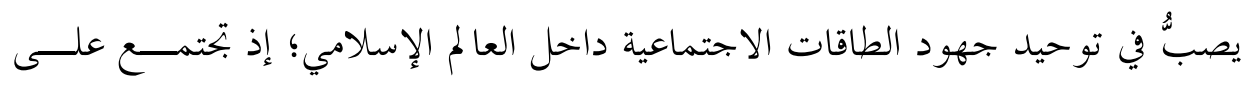

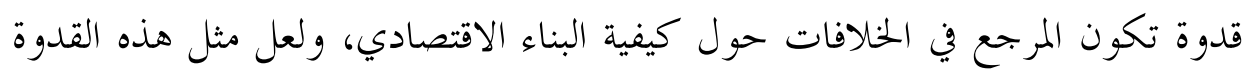

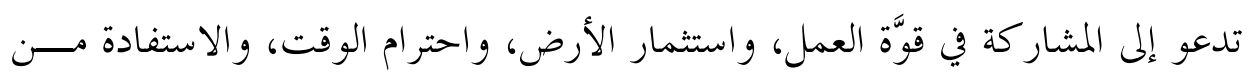

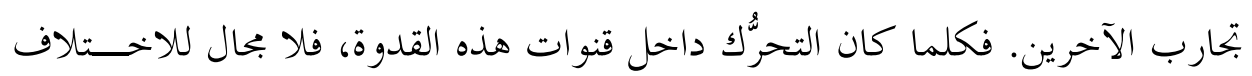

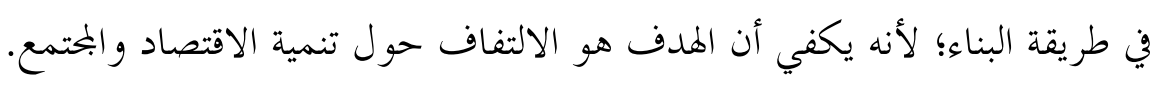

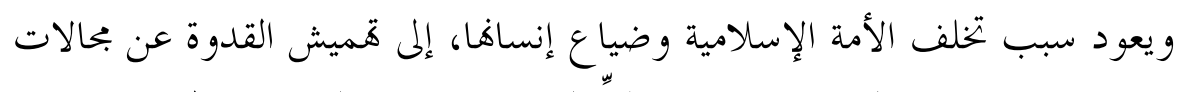

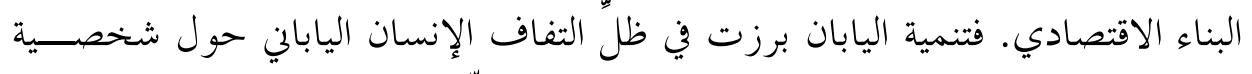

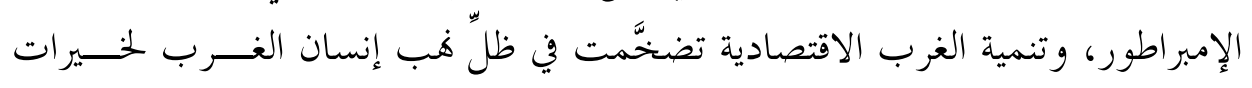

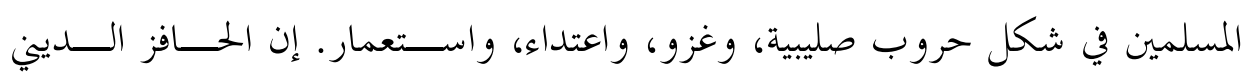

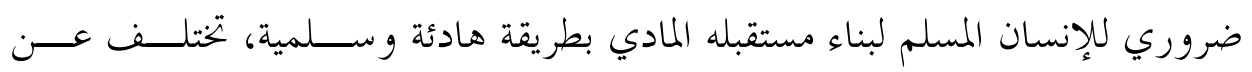

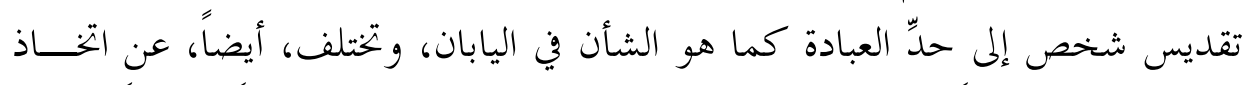

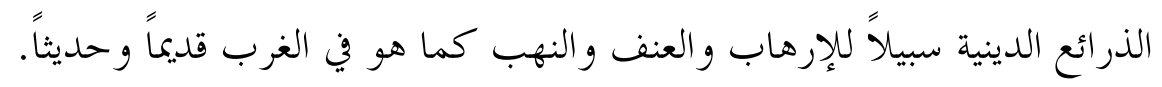

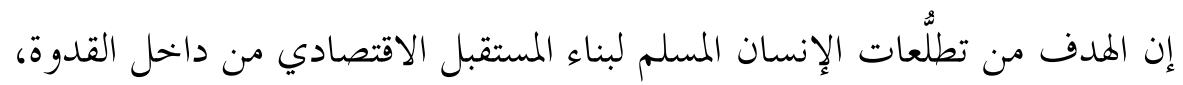

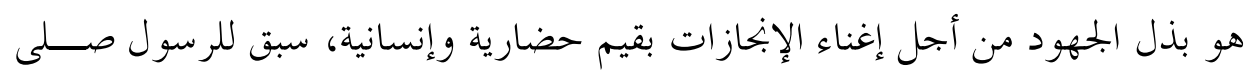

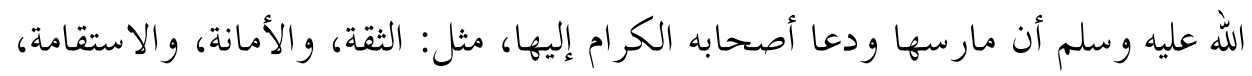

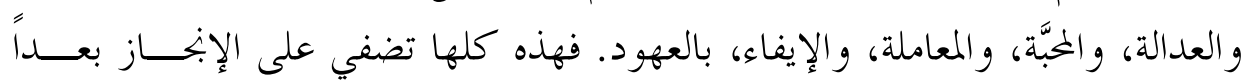

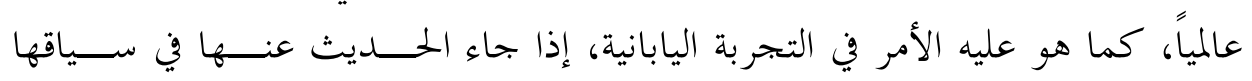

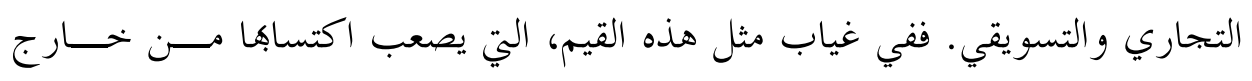

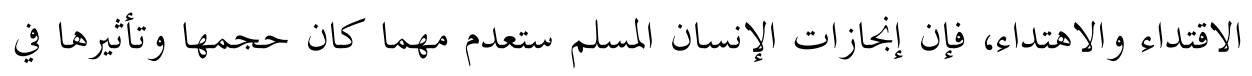

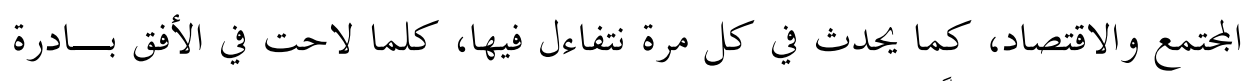
للبناء الاقتصادي المنظمّم و الممنهَج. 
وإذا كان الإنسان المسلم يتَّخذ من الرسول صلى الله عليه وسلم قدوتسهـ لإنخــاز

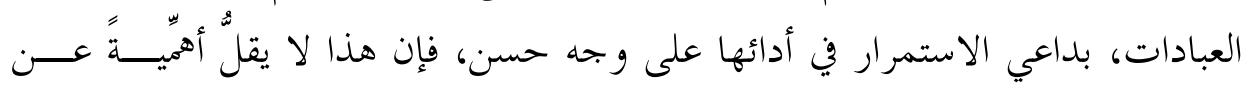

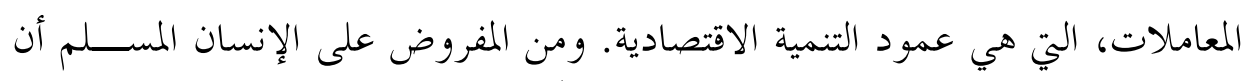

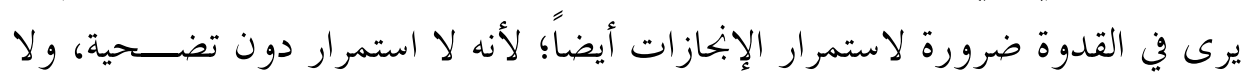

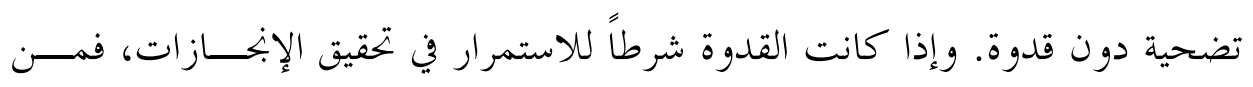

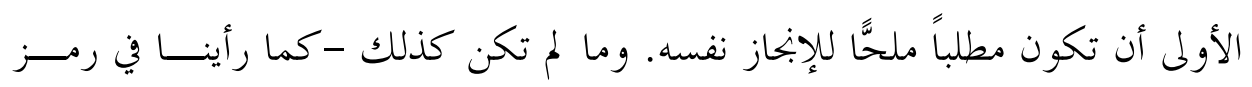

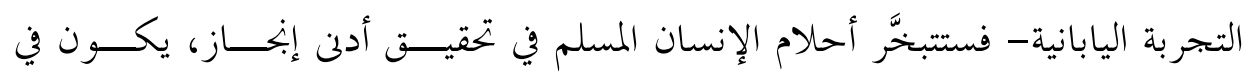

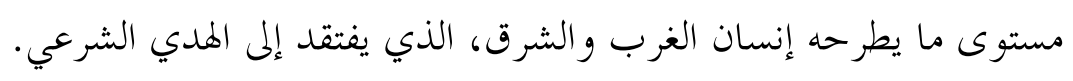

\section{ب. القيادة الحكيمة (= ترشيد فِعْل السلطة):}

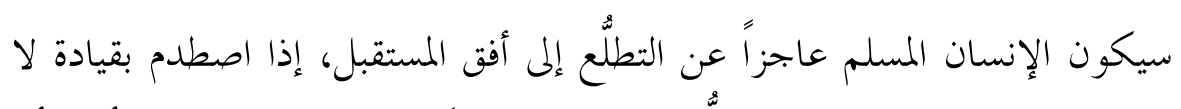

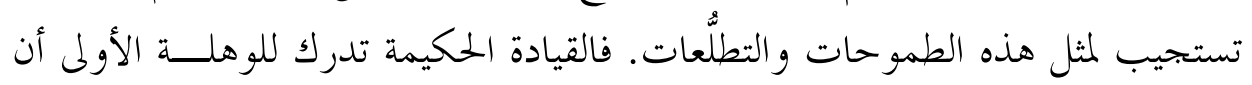

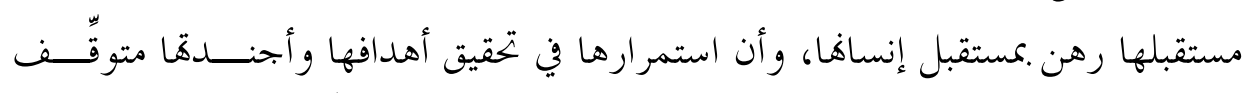

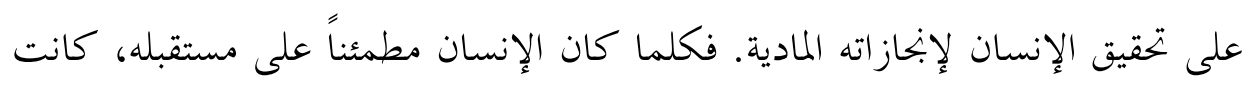

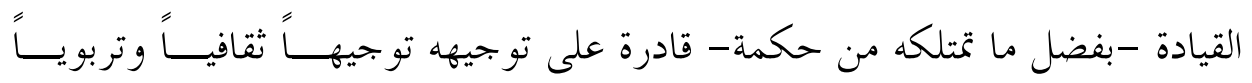

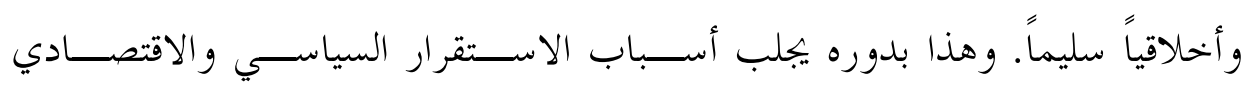

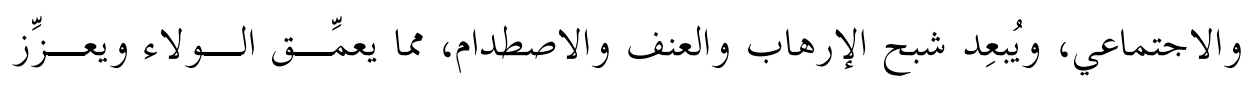
الانتماء.

إن مستقبل الولاء والانتماء متعلّق بحاضر الإنجازات، ومدى تدريب إنسان الأمسـة

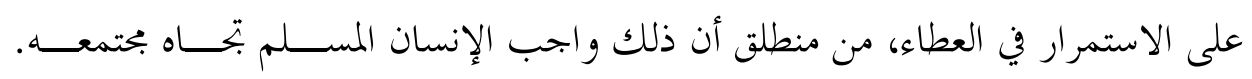

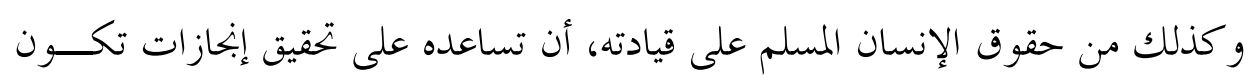

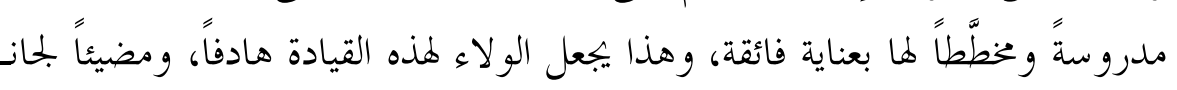

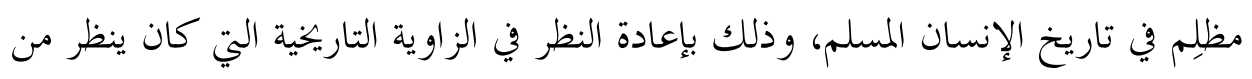

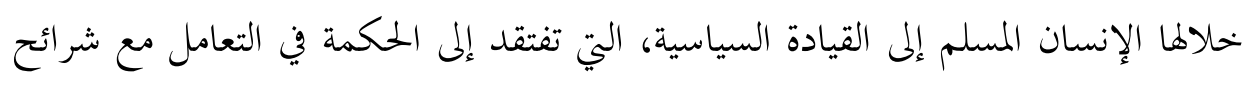


البجتمع. فقليل من الحكمة فيه من الكفاية ما يهوّل وجهة الإنسان المسلم من البراء، الذي

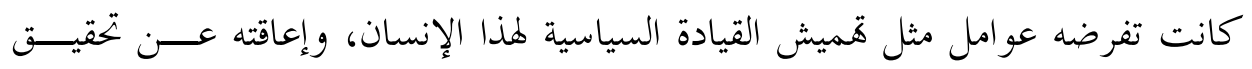

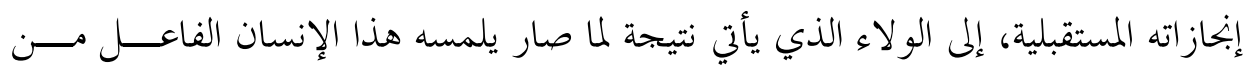

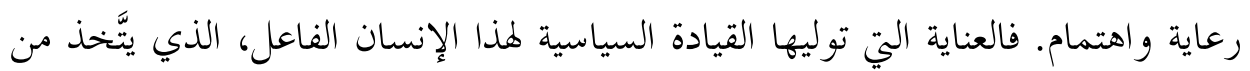

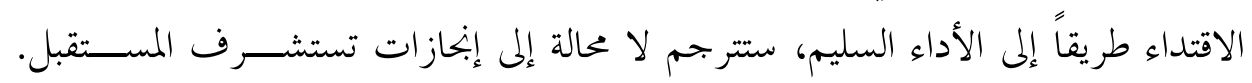

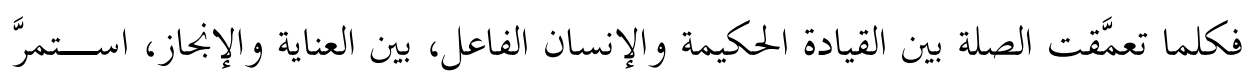
الانتماء في حصاد ثمار الولاء.

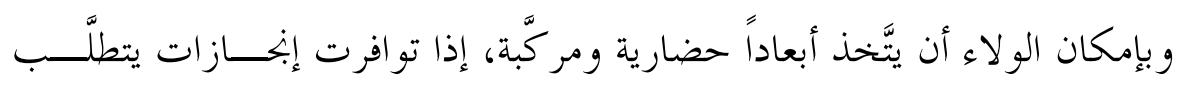

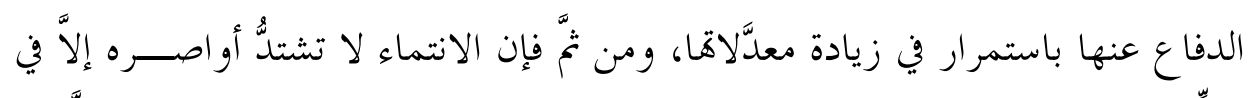

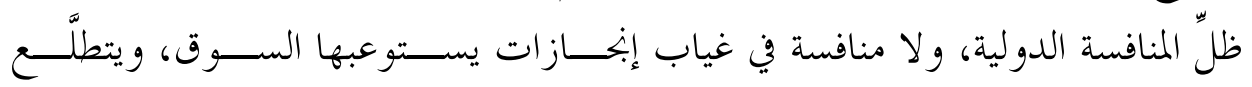

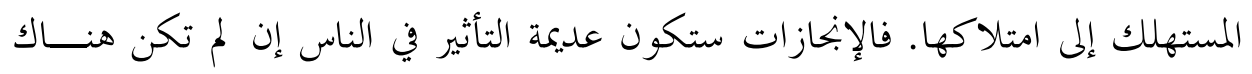

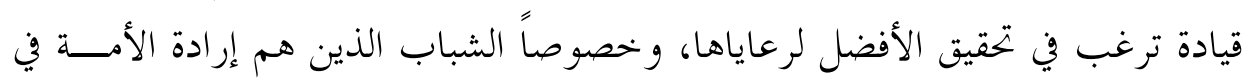

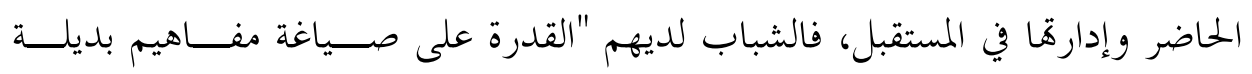

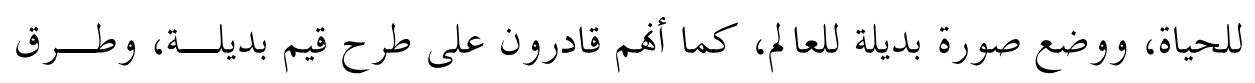

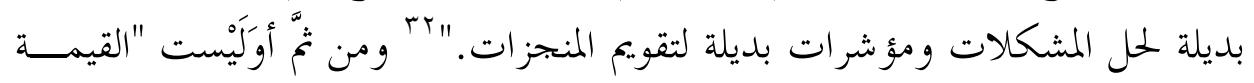

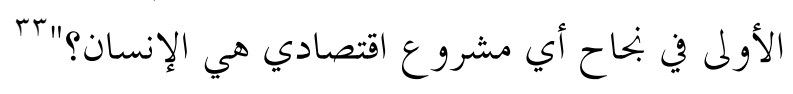

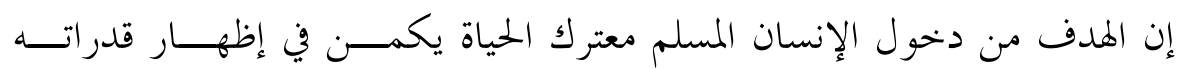

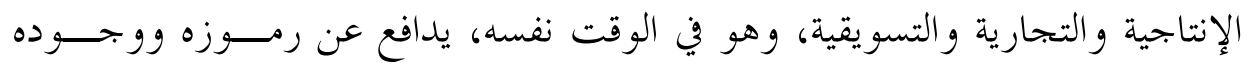

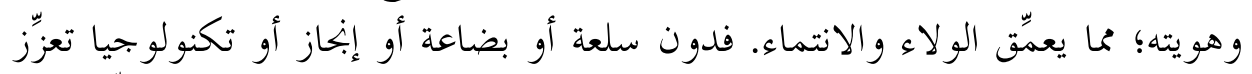

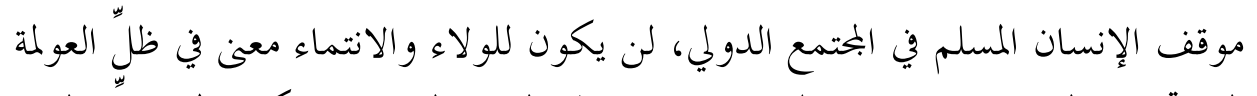

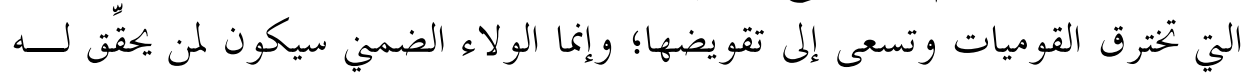

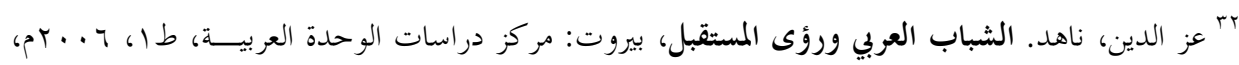
صهr. "r ابن نب، مالك. المسلم في عالم الاقتصاد، بيروت: دار الفكر المعاصر - طبعة جديدة، . ․ rم، صمه. 
إبحازاته. وهنا يأتي دور القيادة السياسية، التي يتطلَّب منها الحكمة في صياغة القرارات

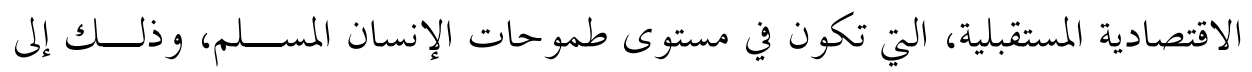

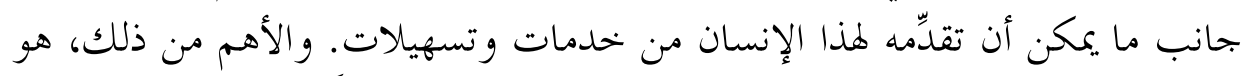

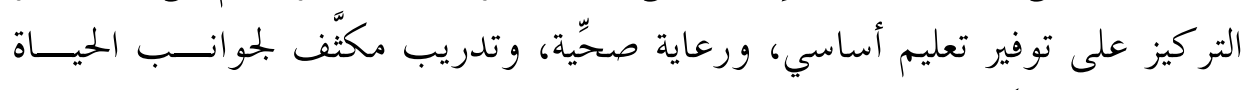

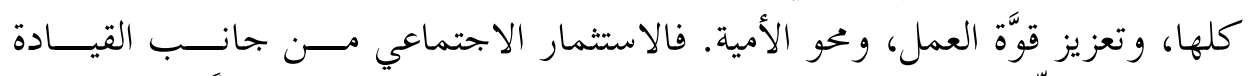

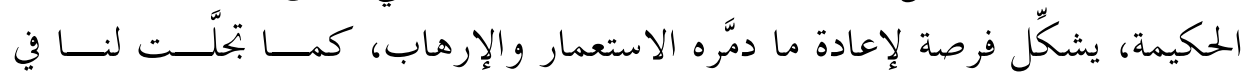

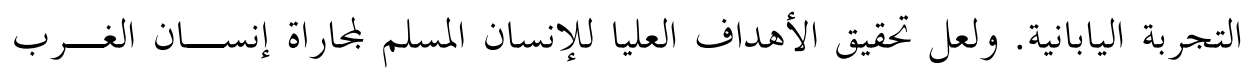

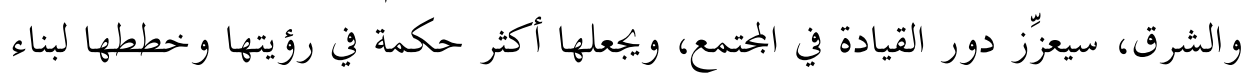
مستقبل الإنسان المسلم.

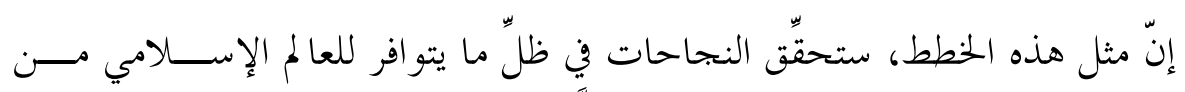

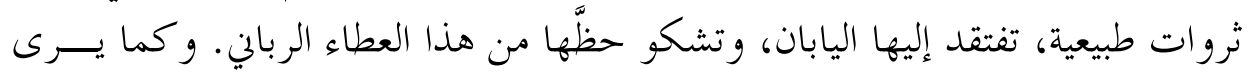

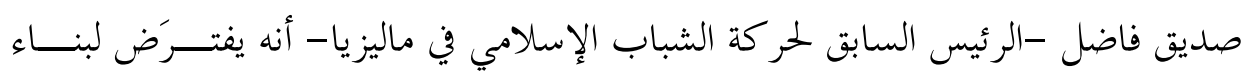

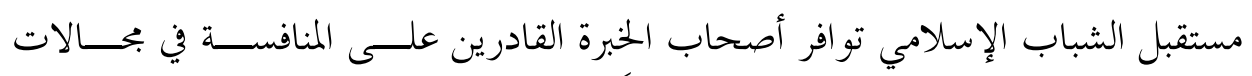

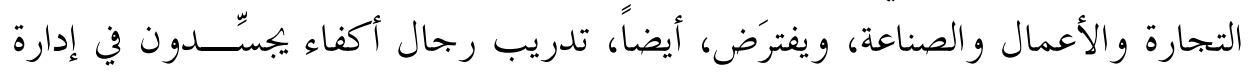

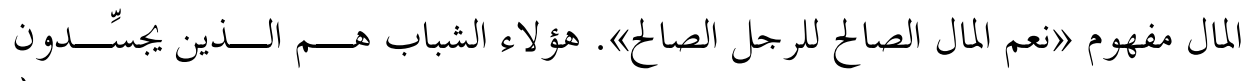

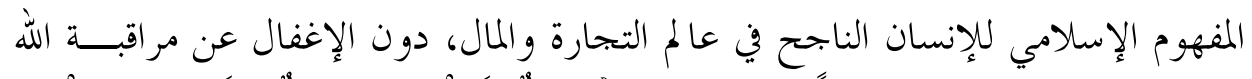

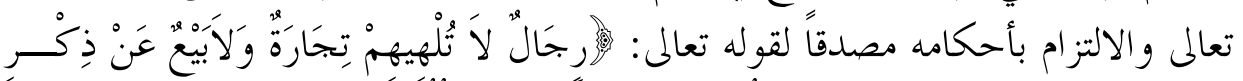

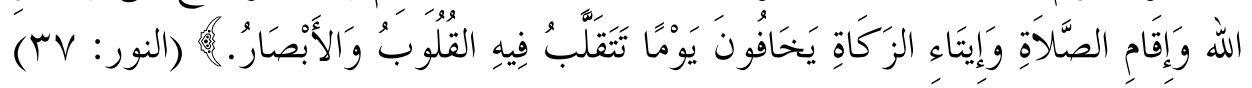

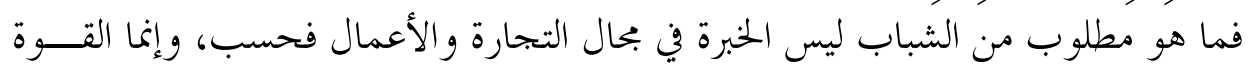

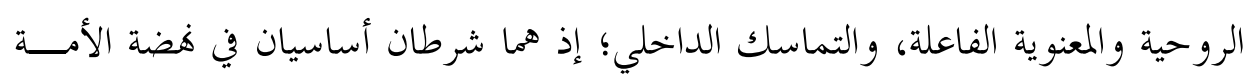
و تقدُّمهـا.

إن بناء قاعدة صلبة يقف عليها مشروع الاستثمار الاجتماعي، بإمكاها أن تفرز

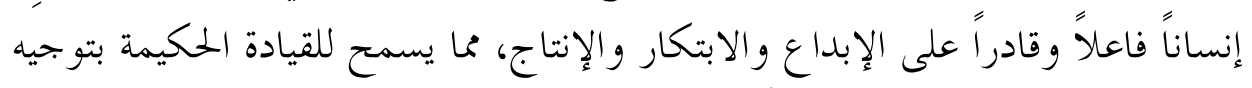

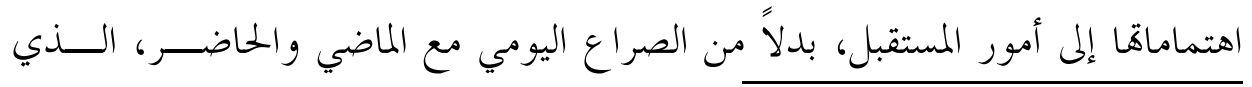

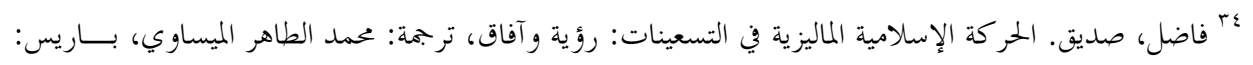

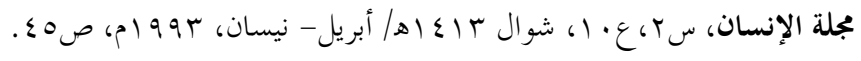


تسهم عو امل الإرهاب و العنف في تضخيمه. و كل هذا ناجم عن قمسـيش الإنســان

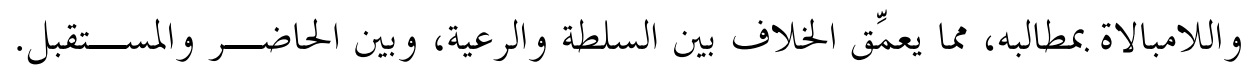

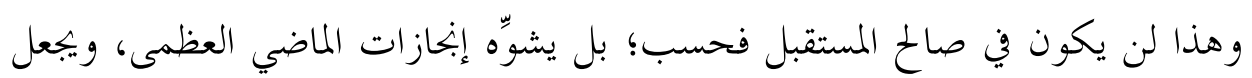

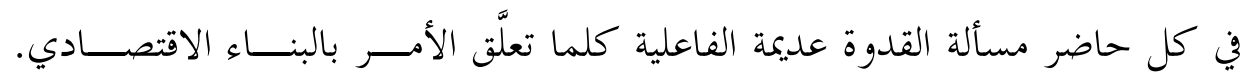

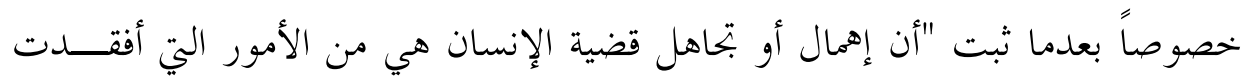

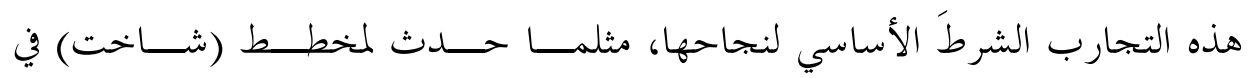

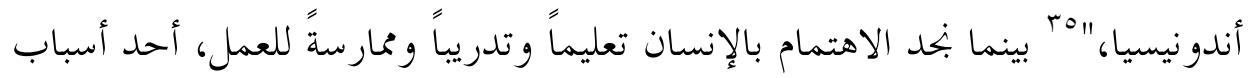
بناح التجارب الاقتصادية في ماليزيا.

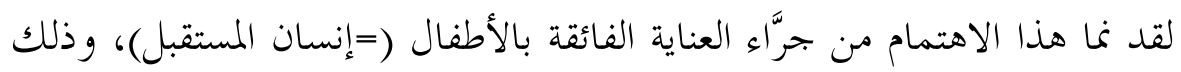

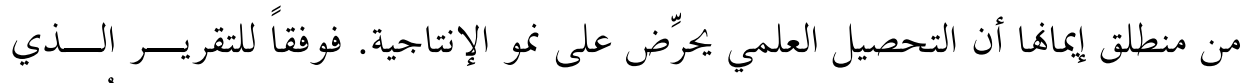

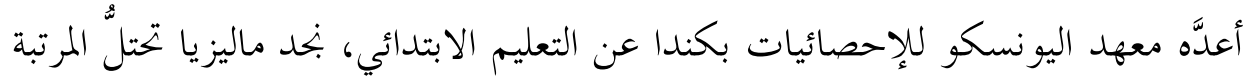

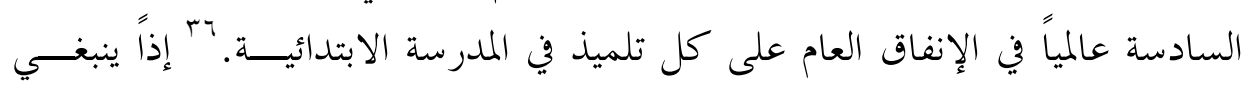

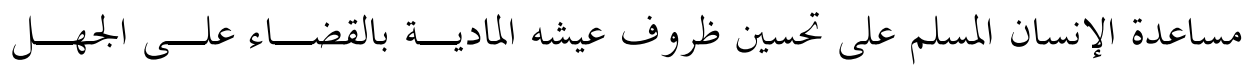

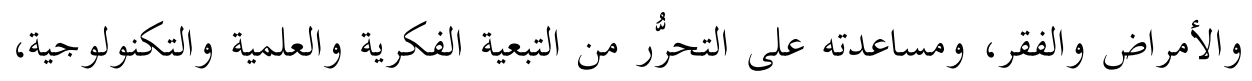

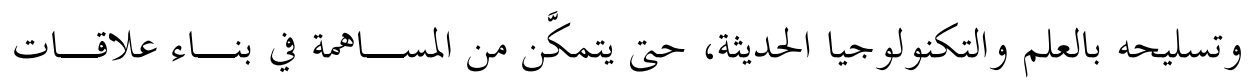

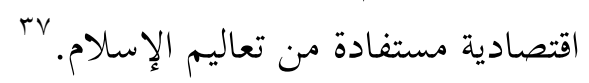

\section{ج. الإنسان الفاعل (=تدويل فعل القيم ):}

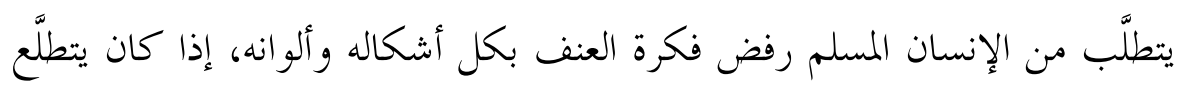

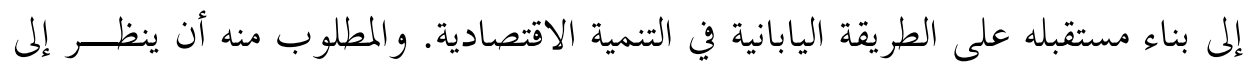

${ }^{36}$ Report Card on Primary Education. Washington: International Fund Monetary, Finance and Development, June 2005, pp24- 25.

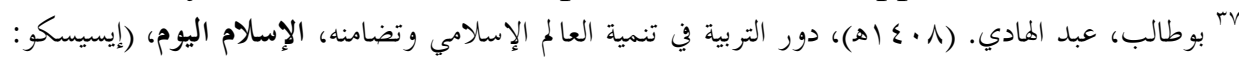

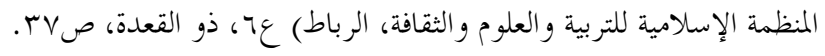




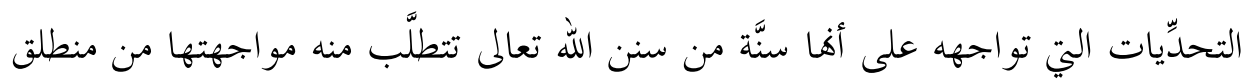

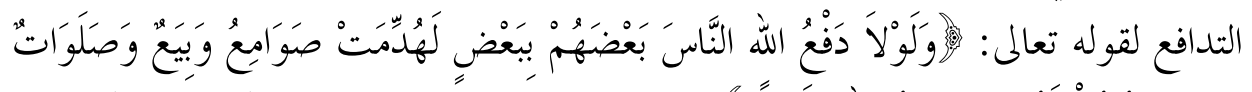

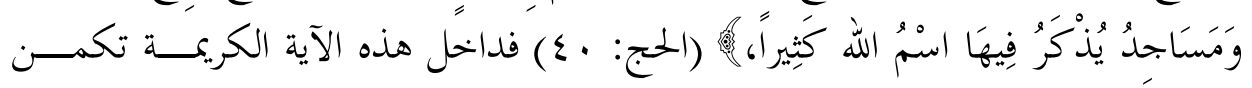

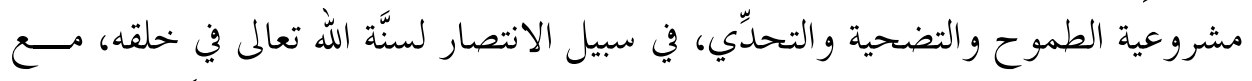

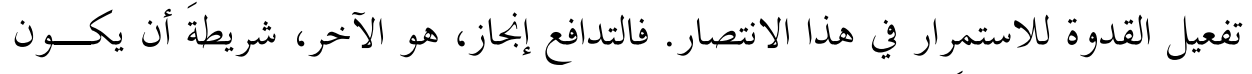

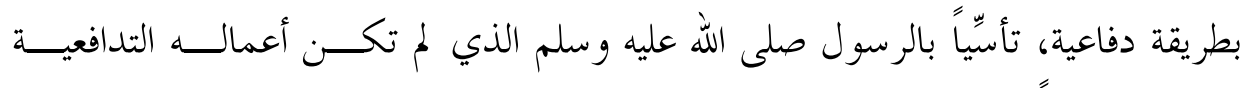
هجومية إطلاقًا.

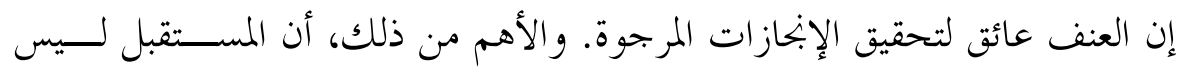

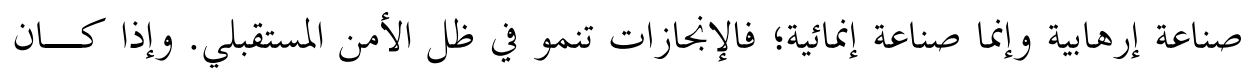

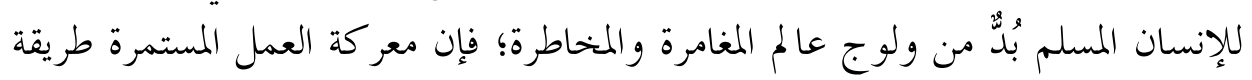

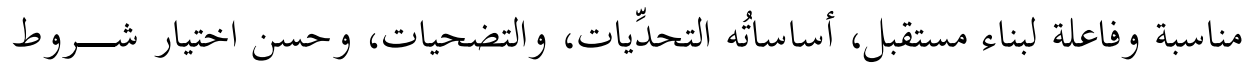

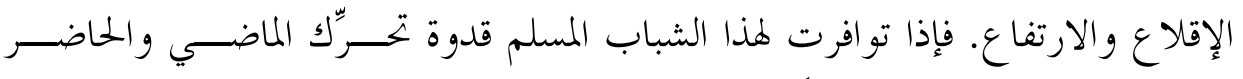

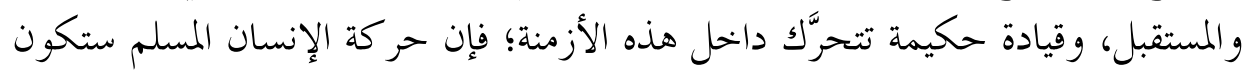

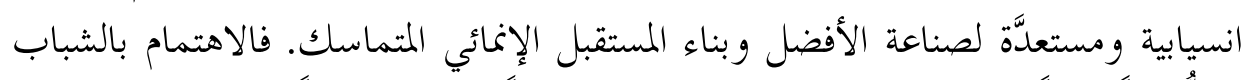

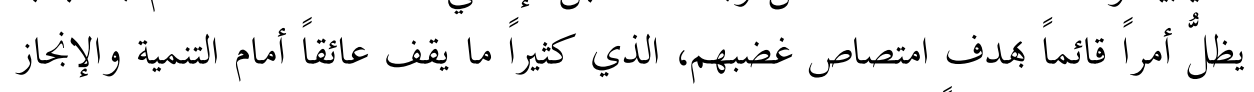

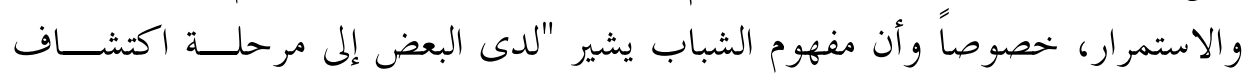

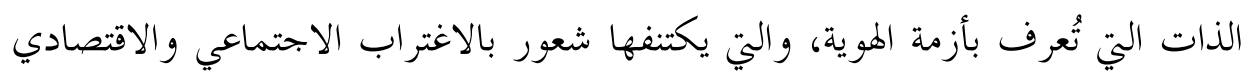

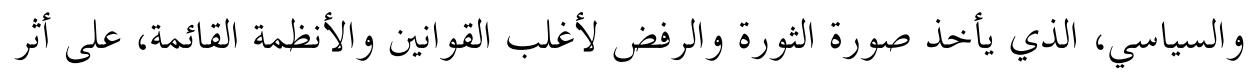

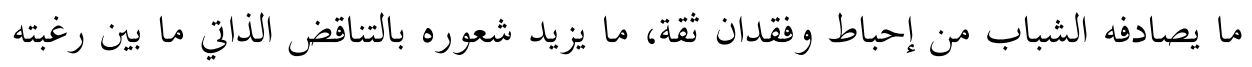

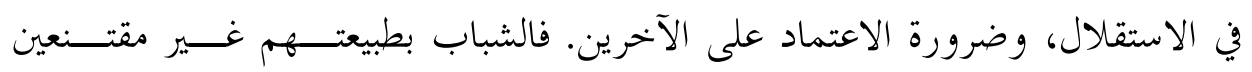

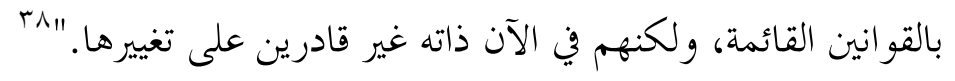

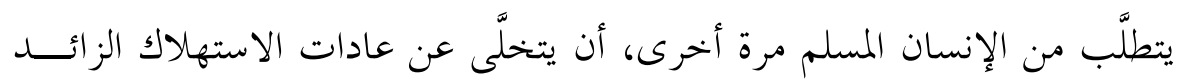

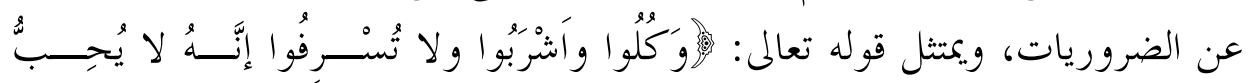

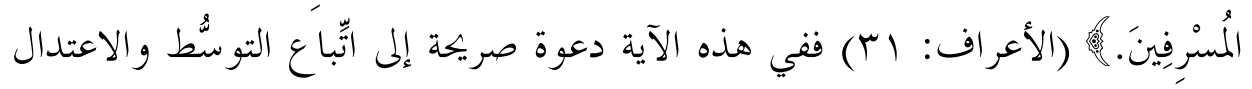




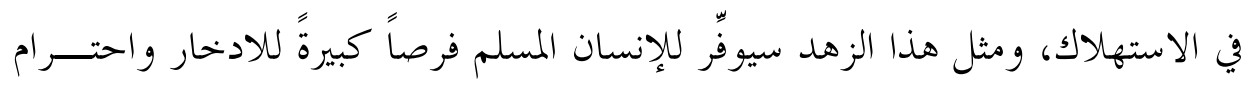

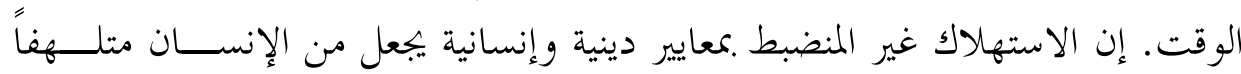

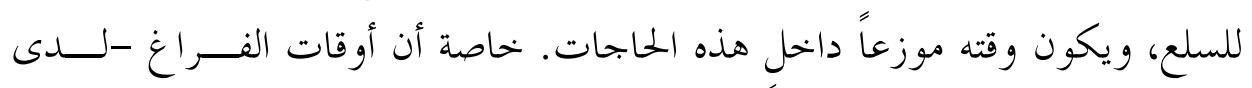

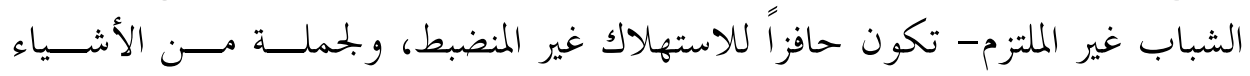

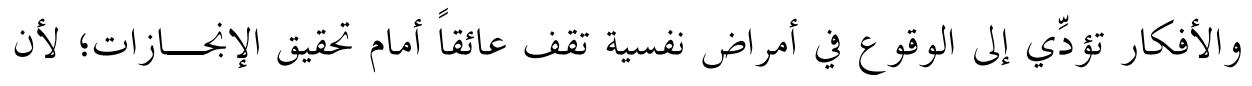

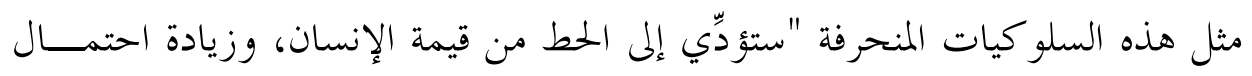

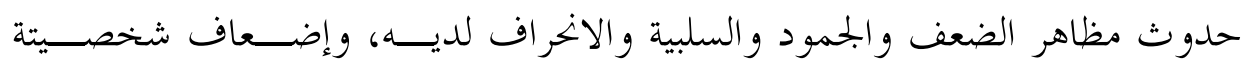

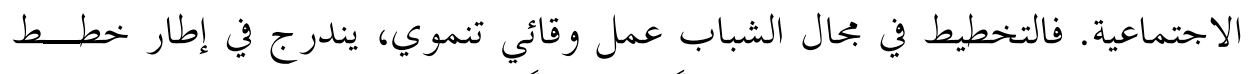

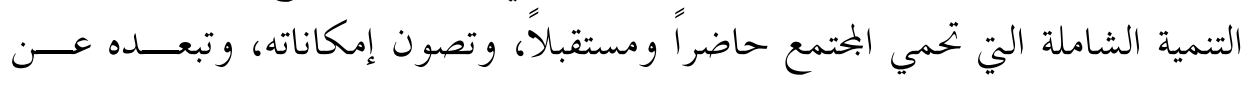

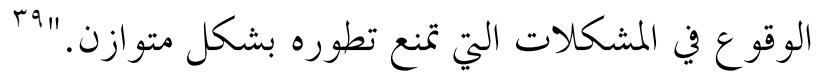

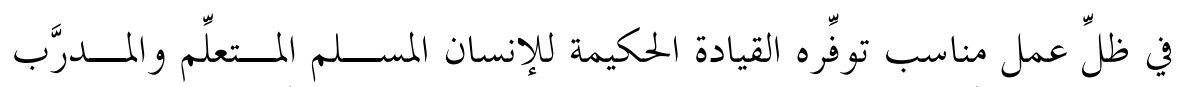

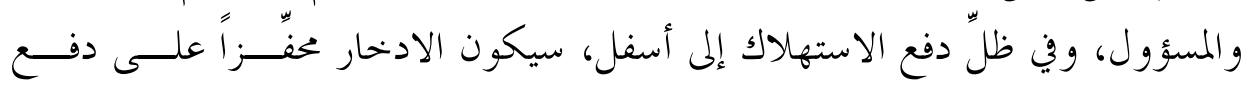

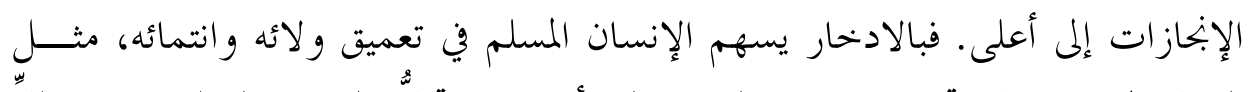

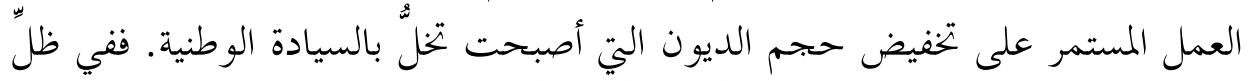

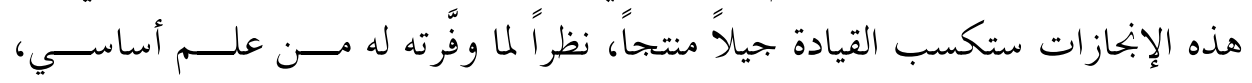

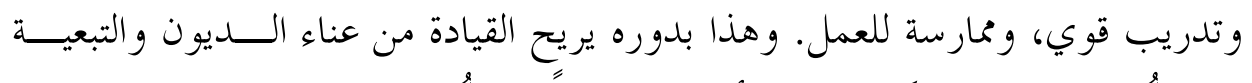

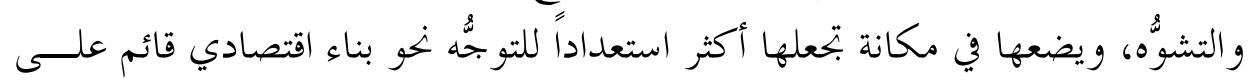

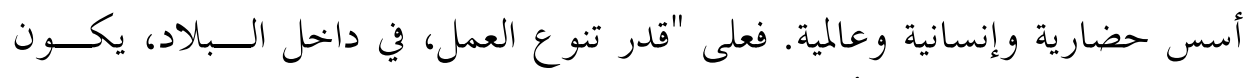

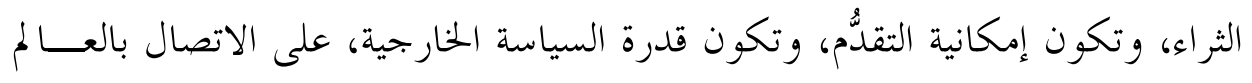

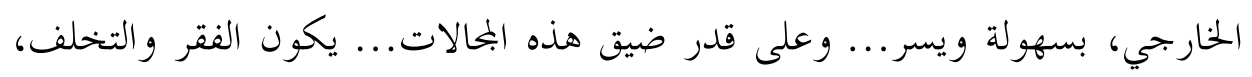

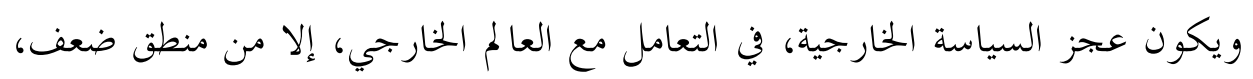

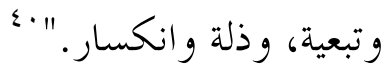

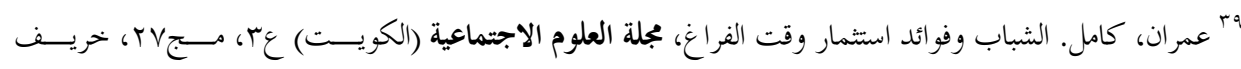

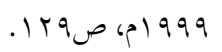

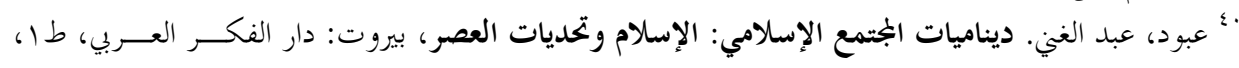




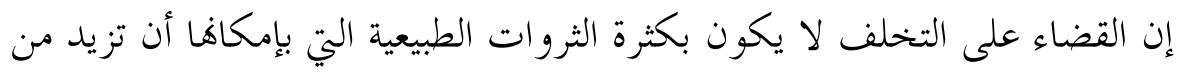

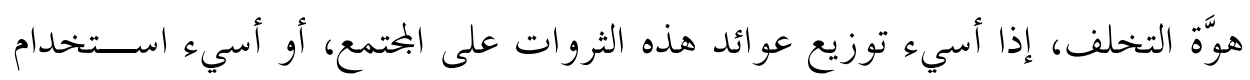

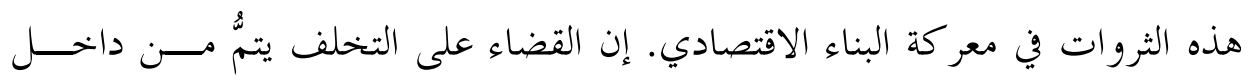

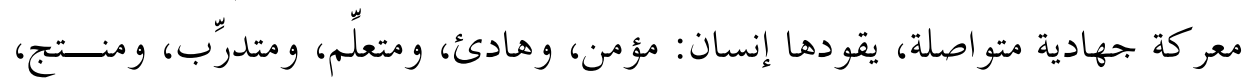

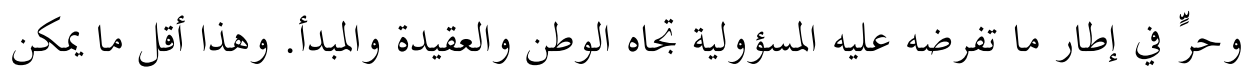

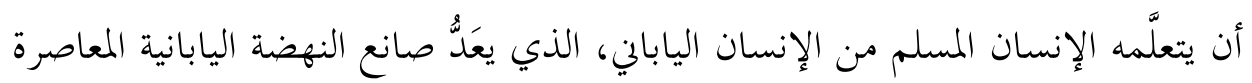
ومهندسها.

\section{خاتمة:}

إن التجربة اليابانية في التنمية الاقتصادية بالخصوص هي تخربة مركَّة في بعسديها

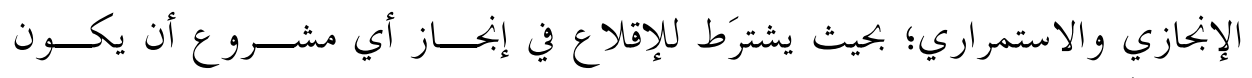

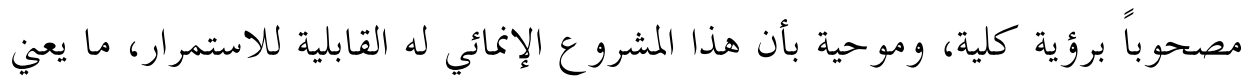

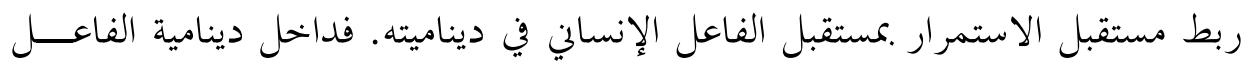

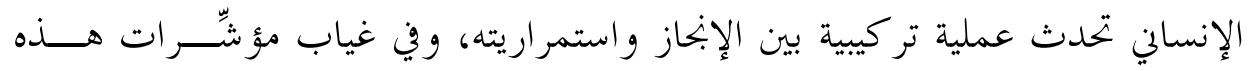

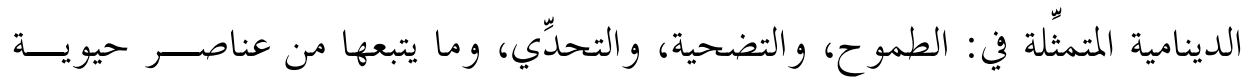

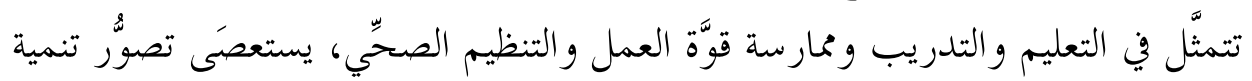

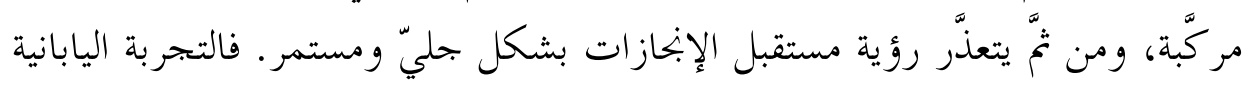

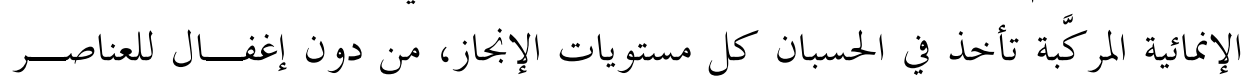

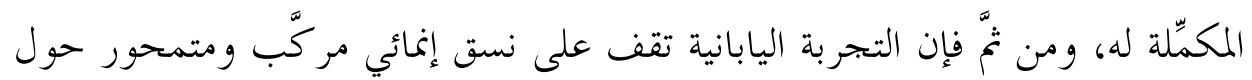

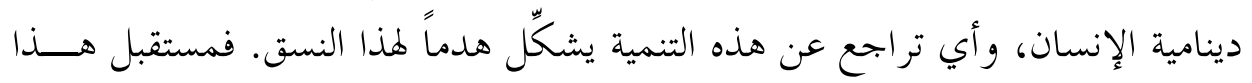

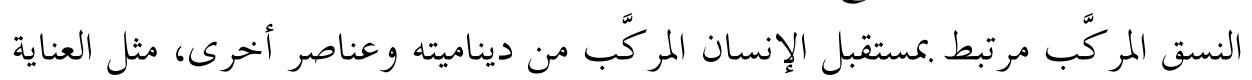

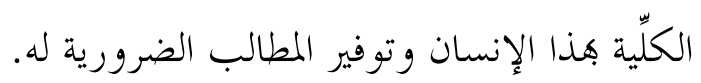

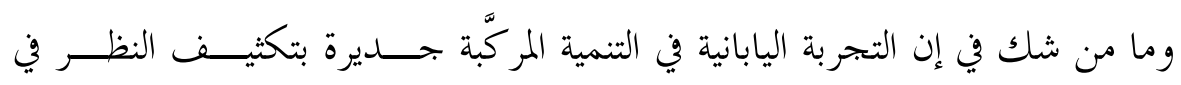

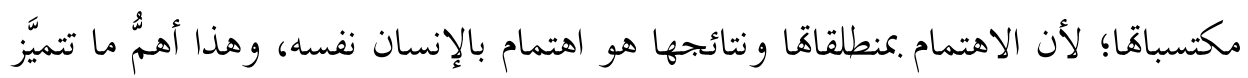




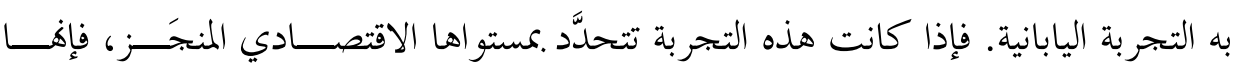
تتجدَّد بمحتواها الإنساني المستمِر. فقد تفوَّقت اليابان في بحال التكنولوجيا والمهارات؛ لأهنا

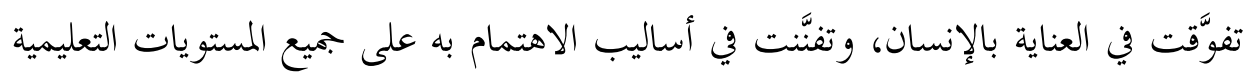
و العلمية و الصحيِّة و المعيشية والترفيهية.

ولا ريب في أن تشكّل دينامية الاعتماد على الذات في التجربة اليابانيـــة ظـــاهرة

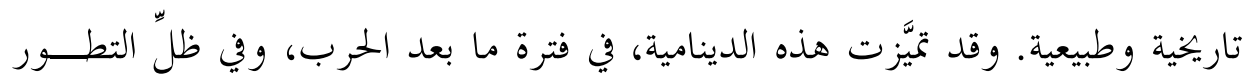

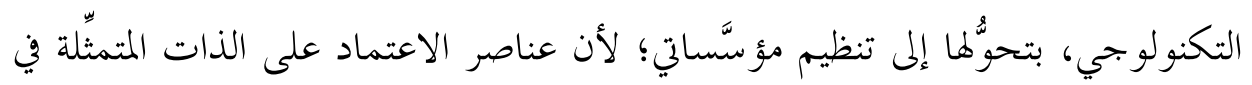

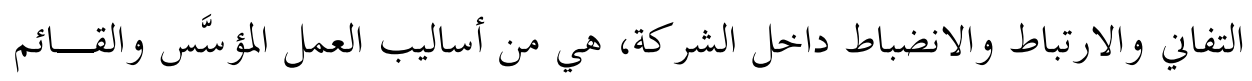
على مبادىء ومعايير وقيم، و بالتالي فإن الاعتماد على الذات داخل المؤسَّة اليابانية لم

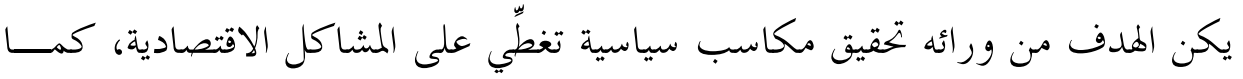
كان عليه الأمر في الدول الاشتراكية؛ وإنما استهدف الاعتماد على الذات في اليابـــان

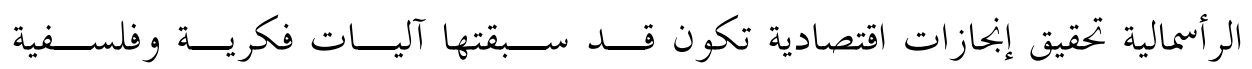

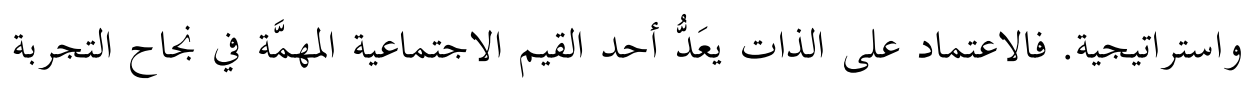

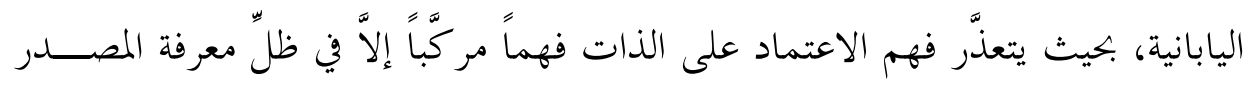

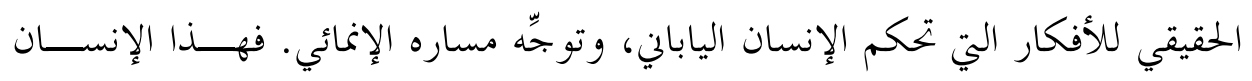

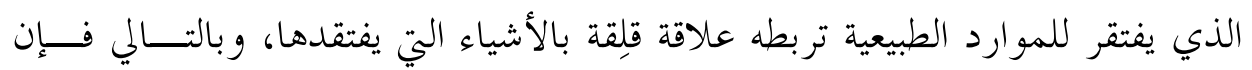

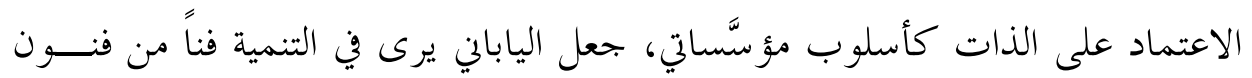

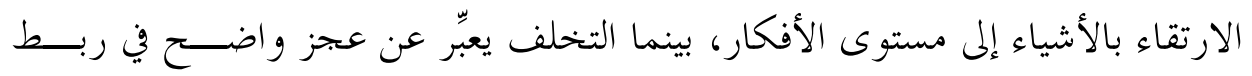
الأشياء بالأفكار.

و التجربة اليابانية في التنمية المركبّة، حصيلة عملية تاريخية مثمِرة، ومتوَّجة بإبــداع

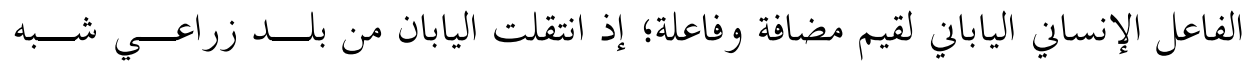
متخلف إلى عملاق صناعي وتكنولوجي، كما انتقلت من بحتمع الإقطاع إلى فوضسىى

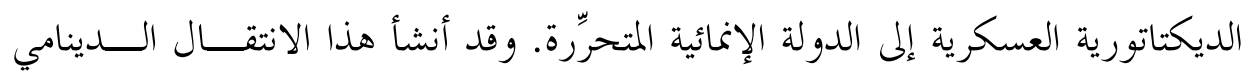


أنموذجاً إنمائياً متطورًِا. وفضلاً عن ذلك، أضاف الفاعل الإنساني الياباني قيمـــاً جديــــة

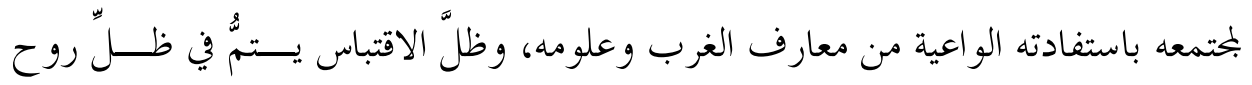

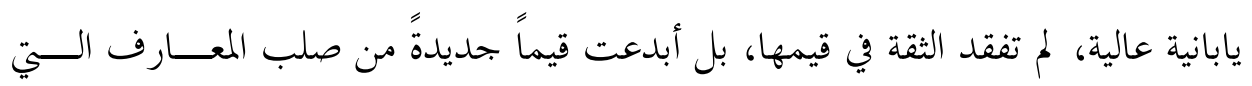
اقتبستها، في بحال الإدارة و التنظيم والتسويق والمنافسة، فقد أصبحت هذه القيم الجديدة

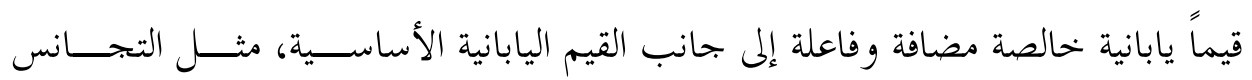
الاجتماعي، والانفتاح على الأفكار الجحديدة، واحترام الأمة والدولة، ومحاسبة المسؤولين. إنّ استفادة ماليزيا -التي تنتمي إلى العالم الإسلامي- من التجربة اليابانية، لا يعود

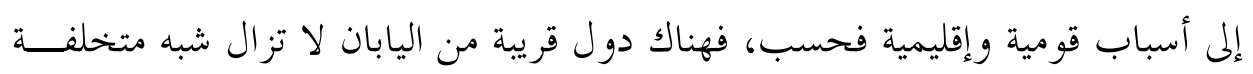

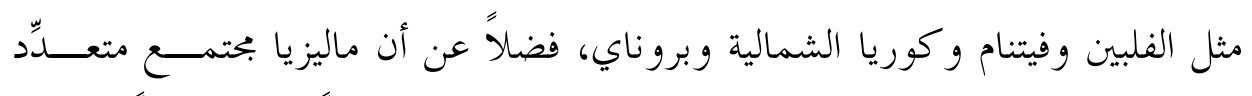

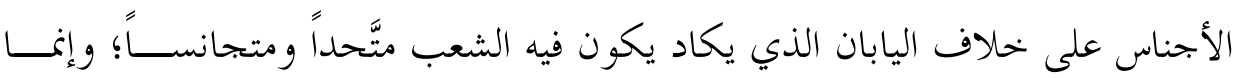
يرجع بحاح ماليزيا إلى إها استطاعت أن تُكسبب شعبها غير المتجانس ثقافة اقتصــادية

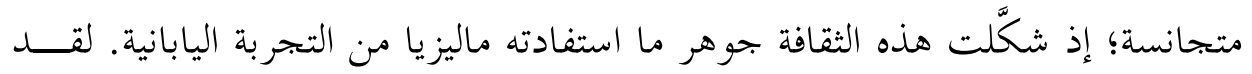

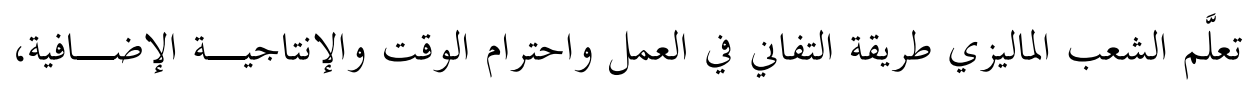

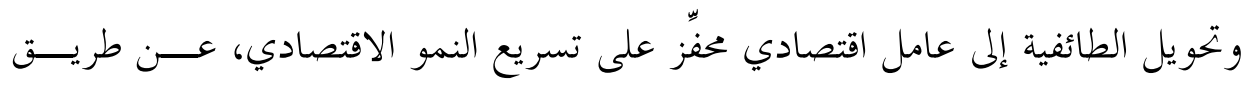

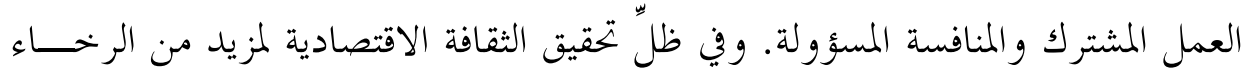

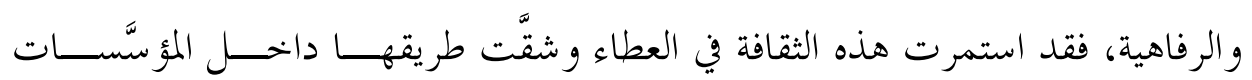
السياسية والاقتصادية، التي ارتبط مستقبلها الإنمائي .كستقبل هذه الثقافة، فباتت تشكلِّل

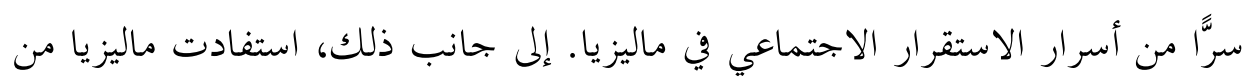

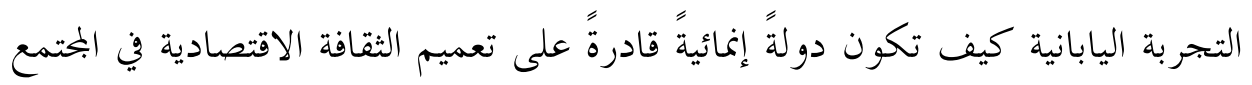

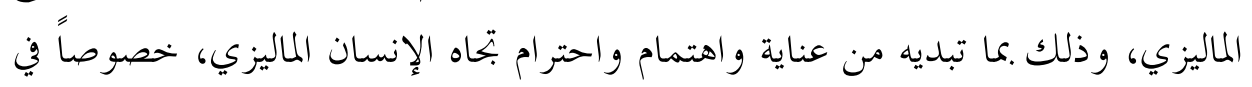

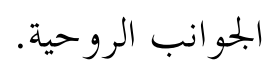

إنّ العالم الإسلامي عامة، والوطن العربي خحاصة، يفتقد إلى الثقافـــة الاقتصــادية،

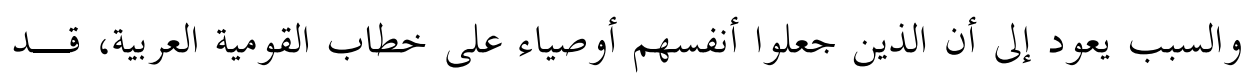




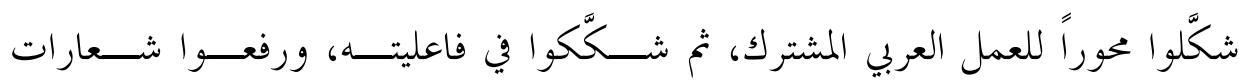

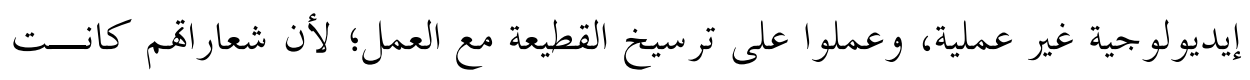

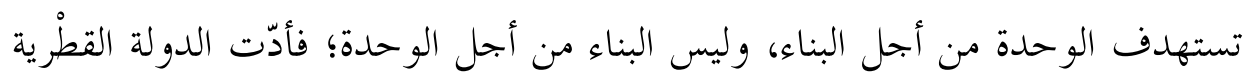

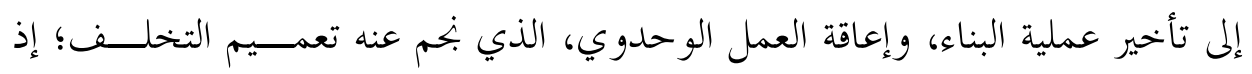

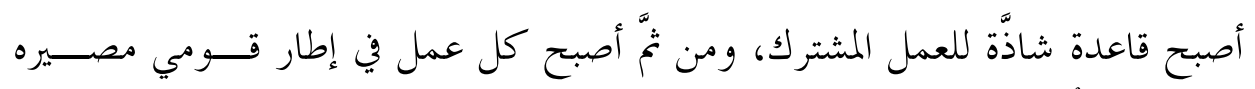
الفشل و التعثُ.

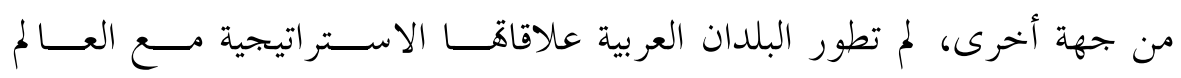

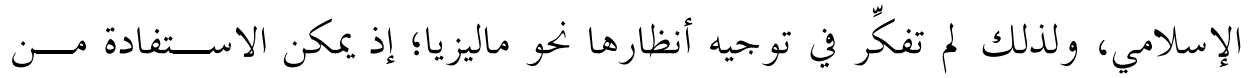

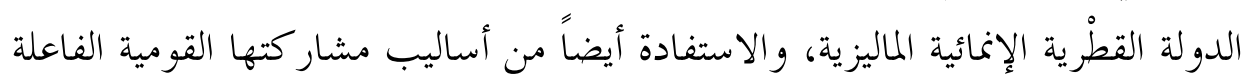

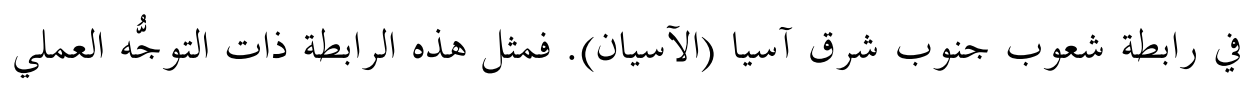

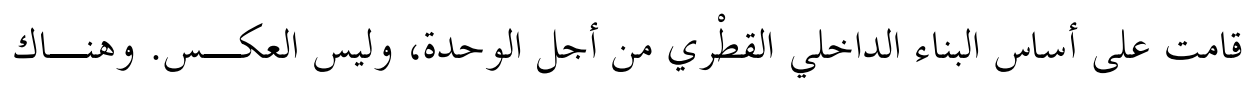

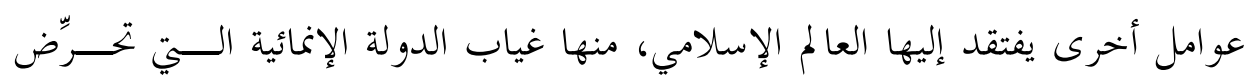

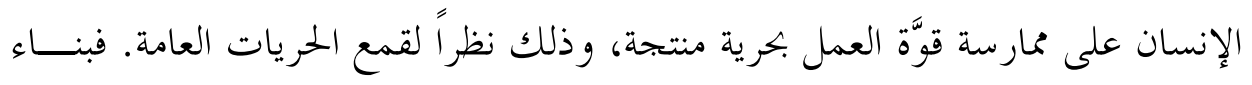

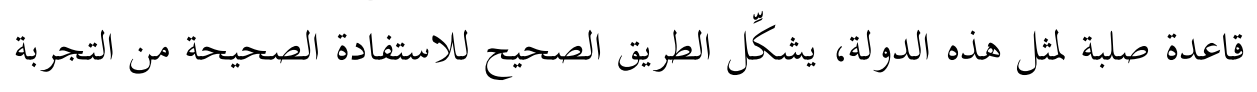
اليابانية.

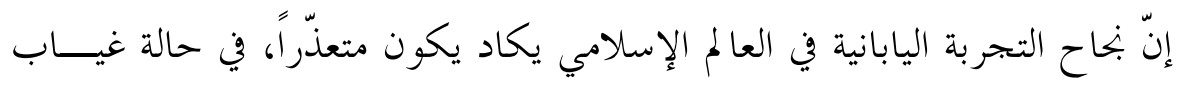

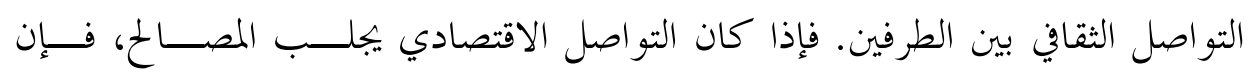

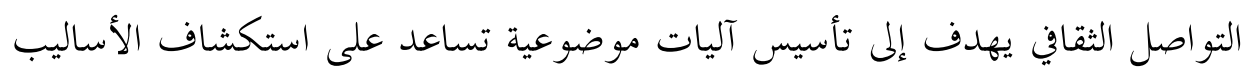

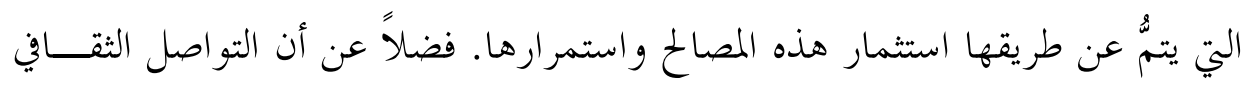

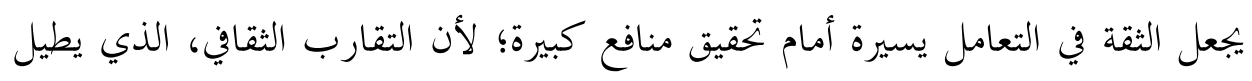

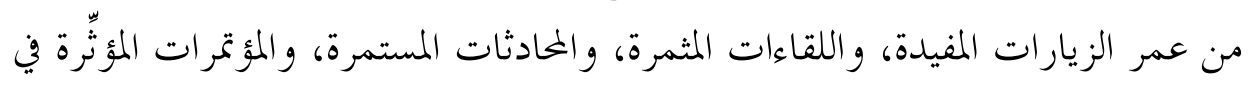

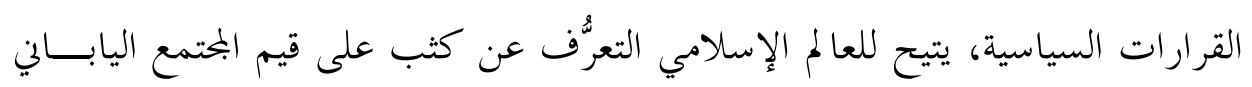

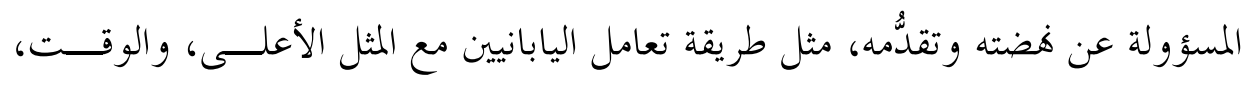


والإنسان، والمؤسَّسة، والتنظيم، والحر كة، و الدولة، والدِّين، والقانون، إضافة إلى دول

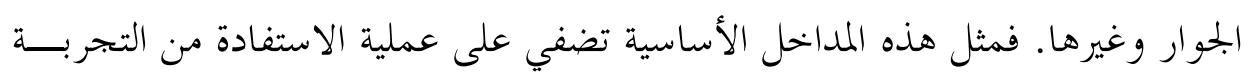
اليابانية طابع الإمكان و التحقيق في العالم الإسلامي.

واستخلاصاً للتحليلات السابقة للموضوع، يرى الباحث أن هناك عدَّة توصيات

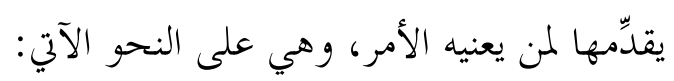

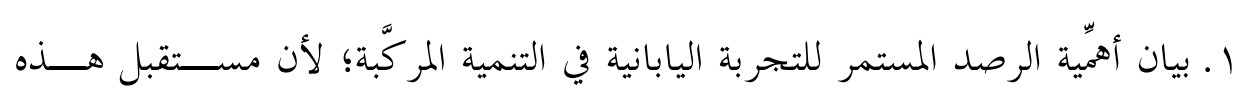

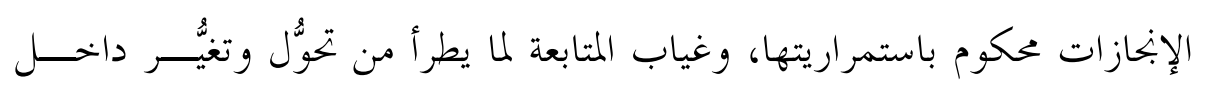

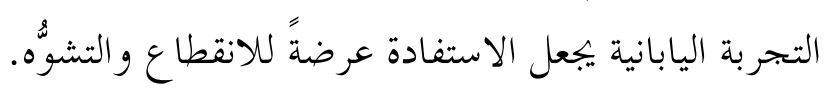

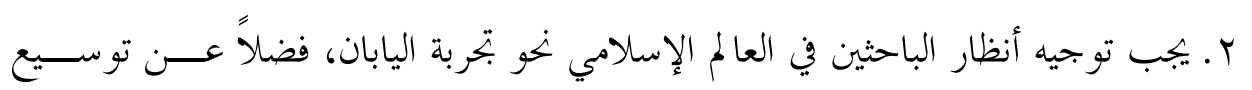

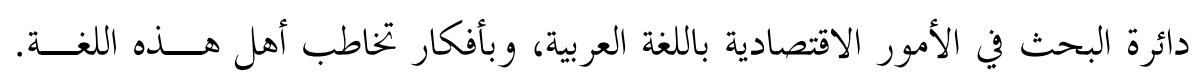

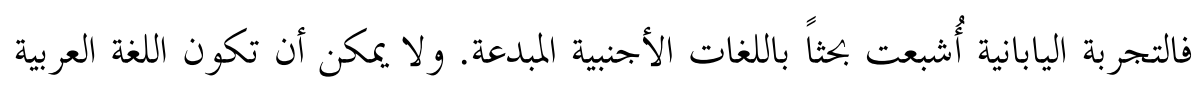
مبدعة في مستوى الإبداع الياباني، إذا ظلَ أهلها يبدعون بغيرها.

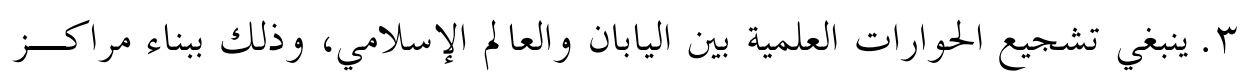

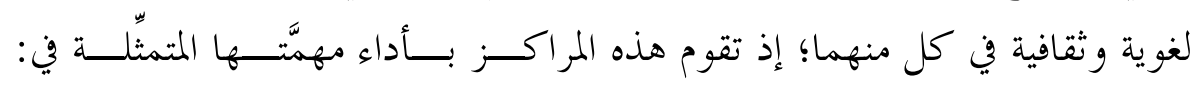

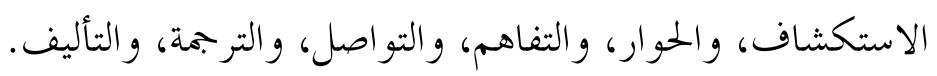

ع. ضرورة التركيز -ـي التعامل التكنولوجي والاستثماري مــع اليابــان- علــى أهميــة

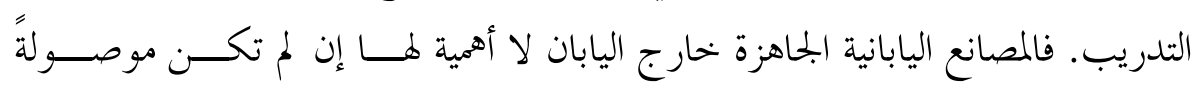

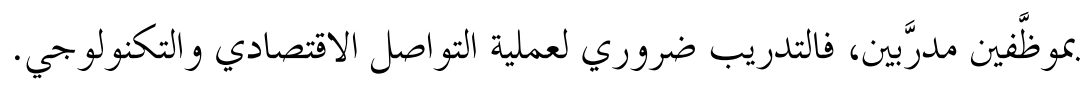

هـ ضرورة التواصل الثقافي بين اليابان و العالم الإسلامي عن طريق تبــادل البــاحثين

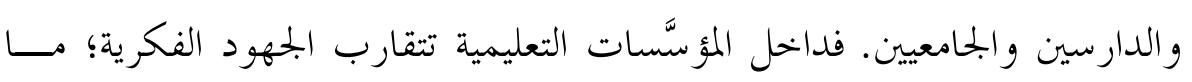

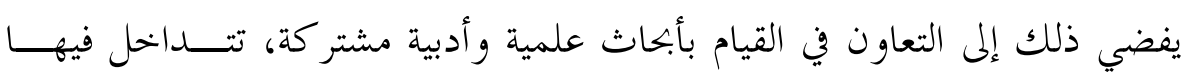

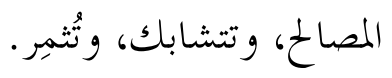


7. دعوة الباحثين ومر اكز الأبحاث في العــالم الإســلامي إلى مراجعــة مفــاهيمهم

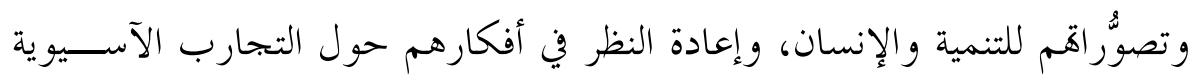

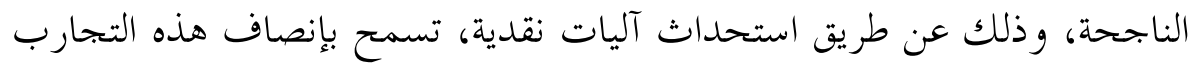

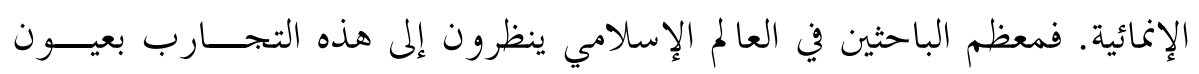

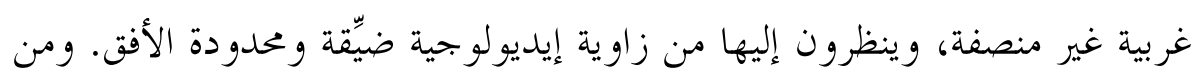

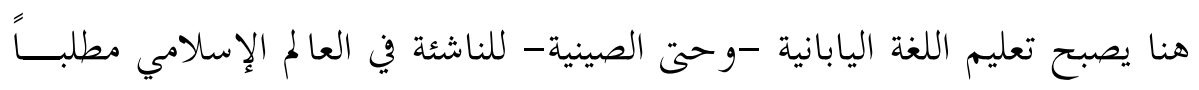

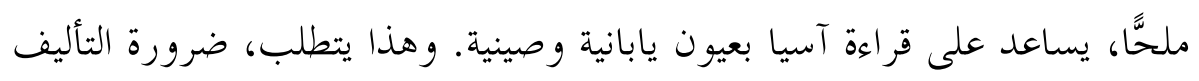

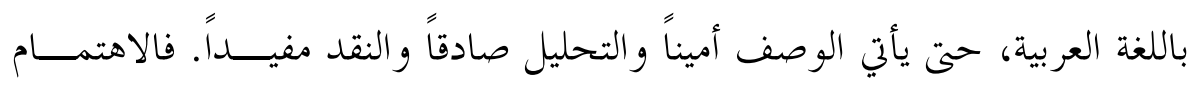

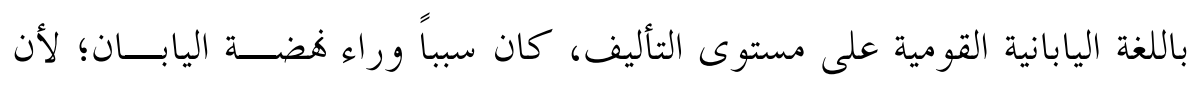

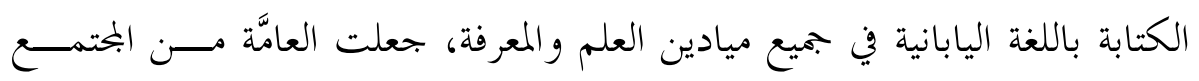

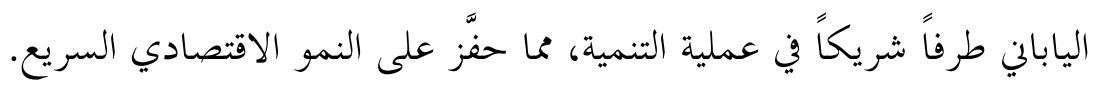
V. ضرورة توجيه الاهتمام نحو إبحاز ات ماليزيا، و التشجيع على بناء مراكز بحثيسة في

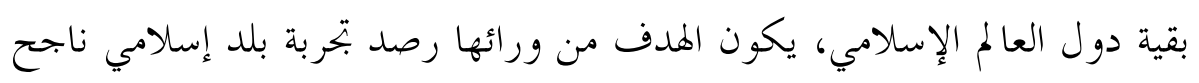
في التنمية الاقتصادية. 